\title{
W ATER-QUALITY ASSESSMENT OF THE RIO GRANDE VALLEY, COLORADO, NEW MEXICO, AND TEXAS-- SHALLOW GROUND-WATER QUALITY AND LAND USE IN THE ALBUQUERQUE AREA, CENTRAL NEW MEXICO, 1993
}

By Scott K. Anderholm

U.S. GEOLOGICAL SURVEY

Water-Resources Investigations Report 97-4067

NATIONAL WATER-QUALITY ASSESSMENT PROGRAM

Albuquerque, New Mexico

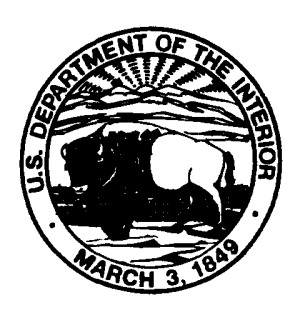




\title{
U.S. DEPARTMENT OF THE INTERIOR \\ BRUCE BABBITT, Secretary
}

\author{
U.S. GEOLOGICAL SURVEY \\ Gordon P. Eaton, Director
}

The use of firm, trade, and brand names in this report is for identification purposes only and does not constitute endorsement by the U.S. Geological Survey.

For additional information write to:

\section{District Chief}

U.S. Geological Survey

Water Resources Division

4501 Indian School Road NE, Suite 200

Albuquerque, NM 87110-3929
Copies of this report can be purchased from:

\author{
U.S. Geological Survey \\ Branch of Information Services \\ Box 25286 \\ Denver, CO 80225-0286
}




\section{FOREWORD}

The mission of the U.S. Geological Survey (USGS) is to assess the quantity and quality of the earth resources of the Nation and to provide information that will assist resource managers and policymakers at Federal, State, and local levels in making sound decisions. Assessment of water-quality conditions and trends is an important part of this overall mission.

One of the greatest challenges faced by waterresources scientists is acquiring reliable information that will guide the use and protection of the Nation's water resources. That challenge is being addressed by Federal, State, interstate, and local water-resource agencies and by many academic institutions. These organizations are collecting water-quality data for a host of purposes that include: compliance with permits and water-supply standards; development of remediation plans for a specific contamination problem; operational decisions on industrial, wastewater, or watersupply facilities; and research on factors that affect water quality. An additional need for water-quality information is to provide a basis on which regional and national-level policy decisions can be based. Wise decisions must be based on sound information. As a society we need to know whether certain types of water-quality problems are isolated or ubiquitous, whether there are significant differences in conditions among regions, whether the conditions are changing over time, and why these conditions change from place to place and over time. The information can be used to help determine the efficacy of existing waterquality policies and to help analysts determine the need for and likely consequences of new policies.

To address these needs, the Congress appropriated funds in $\mathbf{1 9 8 6}$ for the USGS to begin a pilot program in seven project areas to develop and refine the National Water-Quality Assessment (NAWQA) Program. In 1991, the USGS began full implementation of the program. The NAWQA Program builds upon an existing base of water-quality studies of the USGS, as well as those of other Federal, State, and local agencies. The objectives of the NAWQA Program are to:

-Describe current water-quality conditions for a large part of the Nation's freshwater streams, rivers, and aquifers. time.

-Describe how water quality is changing over

-Improve understanding of the primary natural and human factors that affect water-quality conditions.

This information will help support the development and evaluation of management, regulatory, and monitoring decisions by other Federal, State, and local agencies to protect, use, and enhance water resources.
The goals of the NAWQA Program are being achieved through ongoing and proposed investigations of 60 of the Nation's most important river basins and aquifer systems, which are referred to as study units. These study units are distributed throughout the Nation and cover a diversity of hydrogeologic settings. More than two-thirds of the Nation's freshwater use occurs within the 60 study units and more than two-thirds of the people served by public water-supply systems live within their boundaries.

National synthesis of data analysis, based on aggregation of comparable information obtained from the study units, is a major component of the program. This effort focuses on selected water-quality topics using nationally consistent information. Comparative studies will explain differences and similarities in observed water-quality conditions among study areas and will identify changes and trends and their causes. The first topics addressed by the national synthesis are pesticides, nutrients, volatile organic compounds, and aquatic biology. Discussions on these and other waterquality topics will be published in periodic summaries of the quality of the Nation's ground and surface water as the information becomes available.

This report is an element of the comprehensive body of information developed as part of the NAWQA Program. The program depends heavily on the advice, cooperation, and information from many Federal, State, interstate, Tribal, and local agencies and the public. The assistance and suggestions of all are greatly appreciated.
Robert M. Hirsch Chief Hydrologist 


\section{CONTENTS}

Abstract

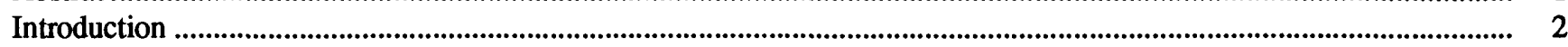

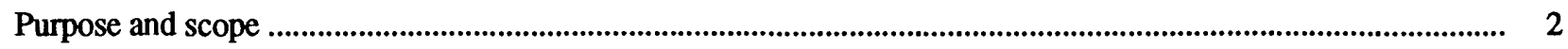

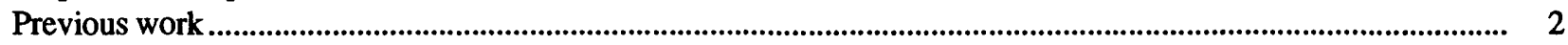

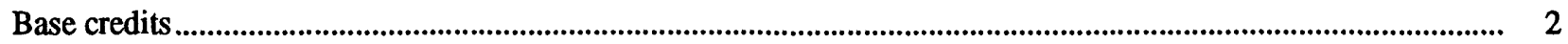

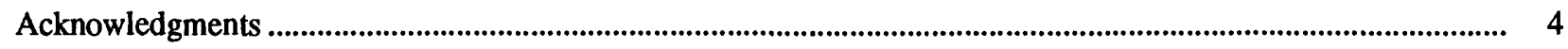

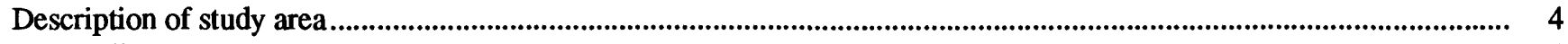

Climate

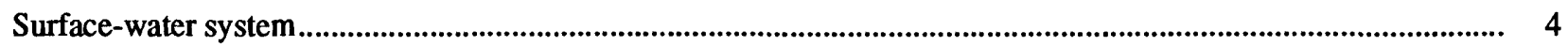

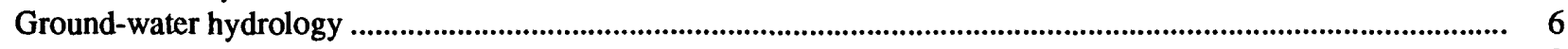

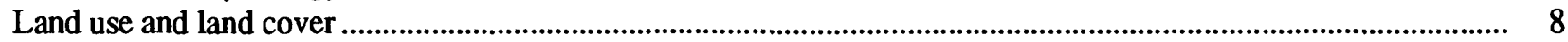

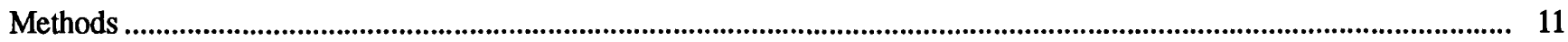

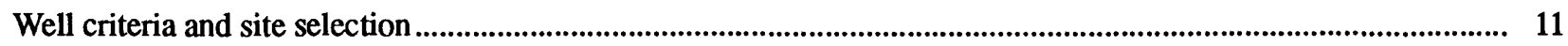

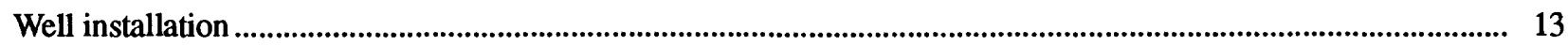

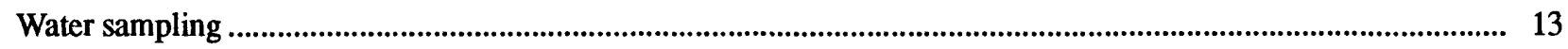

National Water Quality Laboratory methods............................................................................................. 17

Quality assurance/quality control of data ..................................................................................................................... 17

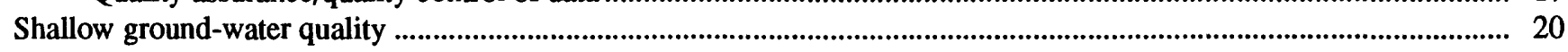

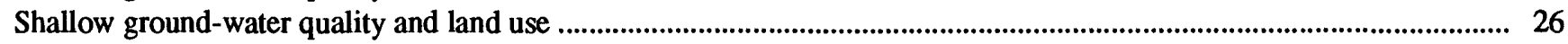

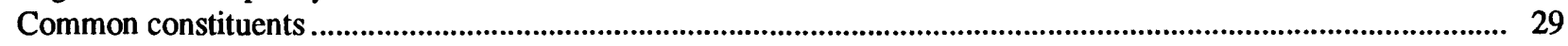

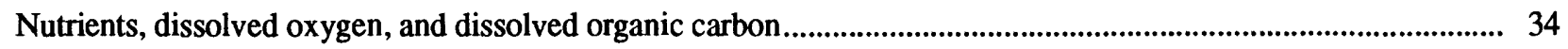

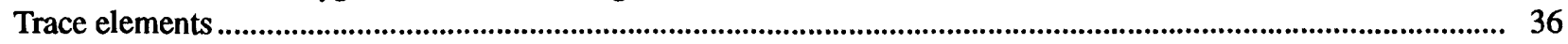

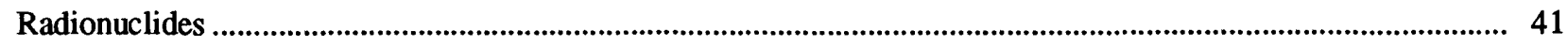

Synthetic organic compounds................................................................................................................................. 44

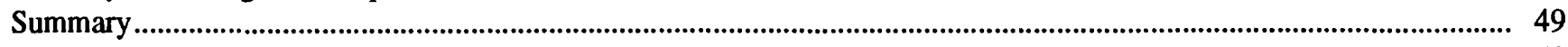

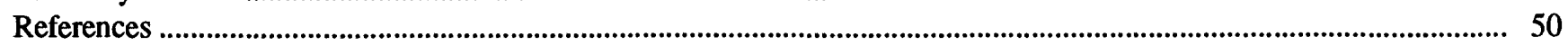

Appendix A Data for shallow ground water in the Albuquerque land-use study area .................................................... 52

Appendix B Results of quality control/quality assurance samples........................................................................................6. 63

\section{FIGURES}

1. Map showing location of the Rio Grande Valley National Water-Quality Assessment (NAWQA) study unit, Albuquerque Basin, and Albuquerque land-use study area .............................................................. 3

2. Map showing location of irrigation canals, ditches, surface drains, and monitoring wells..................................... 5

3. Generalized hydrologic section through the Albuquerque land-use study area ....................................................... 7

4. Map showing potentiometric surface and direction of ground-water flow in the basin-fill aquifer .......................... 9

5. Map showing land use in the Albuquerque land-use study area...................................................................... 10

6. Map showing location of land-use blocks and monitoring wells sampled ........................................................... 12

7. Map showing dissolved solids concentrations in shallow ground water in the Albuquerque land-use

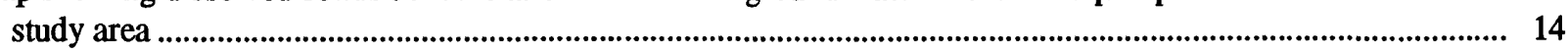

8. Durov plot of shallow ground-water compositions in the Albuquerque land-use study area................................... 24

9. Map showing location and concentrations of nitrite plus nitrate as nitrogen in shallow ground water in the Albuquerque land-use study area.

10. Map showing location and concentrations of volatile organic compounds detected in shallow ground water in the Albuquerque land-use study area. 
11. Map showing location and concentrations of pesticides detected in shallow ground water in the

Albuquerque land-use study area

12. Graphs showing relations between concentrations of (A) chloride and sulfate, (B) chloride and sodium, and $(C)$ chloride and calcium in shallow ground water in the Albuquerque land-use study area

13. Map showing population density and location of permitted septic systems installed prior to 1988 in the Albuquerque area.

14. Graph showing relation between concentrations of dissolved organic carbon and dissolved oxygen in shallow ground water in the Albuquerque land-use study area.

15. Graphs showing relations between concentrations of (A) dissolved nitrite plus nitrate and dissolved oxygen, (B) dissolved nitrite plus nitrate and dissolved ammonia, and (C) dissolved nitrite plus nitrate and dissolved organic carbon in shallow ground water in the Albuquerque land-use study area

16. Graphs showing relations between (A) dissolved iron and dissolved oxygen concentrations, (B) dissolved iron and dissolved organic carbon concentrations, and (C) dissolved iron concentration and $\mathrm{pH}$ in shallow ground water in the Albuquerque land-use study area

17. Graphs showing relations between (A) dissolved manganese and dissolved oxygen concentrations, (B) dissolved manganese and dissolved organic carbon concentrations, and (C) dissolved manganese concentration and $\mathrm{pH}$ in shallow ground water in the Albuquerque land-use study area .

18. Graph showing relation between dissolved gross alpha activity as uranium and dissolved uranium concentration in shallow ground water in the Albuquerque land-use study area

19. Graphs showing relations between (A) dissolved gross beta activity and dissolved potassium concentration and (B) dissolved gross beta activity adjusted for beta activity due to potassium- 40 and dissolved uranium concentration in shallow ground water in the Albuquerque land-use study area

20. Graph showing relation between radon-222 and dissolved gross alpha activity as uranium in shallow ground water in the Albuquerque land-use study area

21. Graphs showing land use and (A) number of wells sampled, (B) percentage of detections of volatile organic compounds in each land-use category, and (C) percentage of detections of pesticides in each land-use category

22. Graphs showing percentage of different land uses in a 1/4-mile radius around well where (A) volatile organic compounds were detected and (B) pesticides were detected.

\section{TABLES}

1. Analyte constituents and minimum reporting levels or method detection limits

2. Constituents detected in blanks, range of concentrations in blank samples, and range of concentrations in shallow ground water.

3. Statistical summary of selected data for shallow ground water in the Albuquerque land-use study area.

4. Median concentrations of selected constituents in water from the Rio Grande at San Felipe, 1981-90, and average concentrations of selected constituents in precipitation and bulk deposition in the Albuquerque area

5. Land use at the wells sampled and percentages of different land uses in 1/4-mile radius around wells sampled 


\begin{tabular}{rcll}
\hline Multiply & By & To obtain \\
\hline inch & 25.4 & millimeter \\
foot & 0.3048 & meter \\
mile & 1.609 & kilometer \\
acre-foot & 1,233 & cubic meter \\
gallon & 3.785 & liter \\
gallons per minute & 0.06309 & liter per second \\
acre & 4,047 & square meter \\
\hline
\end{tabular}

Temperature in degrees Fahrenheit $\left({ }^{\circ} \mathrm{F}\right)$ may be converted to degrees Celsius $\left({ }^{\circ} \mathrm{C}\right)$ as follows:

$$
{ }^{\circ} \mathrm{C}=5 / 9\left({ }^{\circ} \mathrm{F}-32\right)
$$

Sea level: In this report, "sea level" refers to the National Geodetic Vertical Datum of 1929-a geodetic datum derived from a general adjustment of the first-order level nets of the United States and Canada, formerly called Sea Level Datum of 1929. 


\title{
WATER-QUALITY ASSESSMENT OF THE RIO GRANDE VALLEY, COLORADO, NEW MEXICO, AND TEXAS -- SHALLOW GROUND- WATER QUALITY AND LAND USE IN THE ALBUQUERQUE AREA, CENTRAL NEW MEXICO, 1993
}

\author{
By Scott K. Anderholm
}

\section{Abstract}

This report describes the quality of shallow ground water and the relations between land use and the quality of that shallow ground water in an urban area in and adjacent to Albuquerque, New Mexico. Water samples were collected from 24 shallow wells. Samples were analyzed for selected common constituents, nutrients, trace elements, radionuclides, volatile organic compounds, and pesticides.

The study area, which is in the Albuquerque Basin in central New Mexico, was limited to the Rio Grande flood plain; depth to water in this area generally is less than 25 feet. The amount and composition of recharge to the shallow groundwater system are important factors that affect shallow ground-water composition in this area. Important sources of recharge that affect shallow ground-water quality in the area include infiltration of surface water, which is used in agricultural land-use areas to irrigate crops, and infiltration of septic-system effluent in residential areas. Agricultural land use represents about 28 percent of the area, and residential land use represents about 35 percent of the total study area. In most of the study area, agricultural land use is interspersed with residential land use and neither is the dominant land use in the area. Land use in the study area historically has been changing from agricultural to urban.

The composition of shallow ground water in the study area varies considerably. The dissolved solids concentration in shallow ground water in the study area ranges from 272 to 1,650 milligrams per liter, although the relative percentages of selected cations and anions do not vary substantially. Calcium generally is the dominant cation and bicarbonate generally is the dominant anion. Concentrations of nutrients generally were less than 1 milligram per liter. The concentration of many trace elements in shallow ground water was below or slightly above 1 microgram per liter and there was little variation in the concentrations. Barium, iron, manganese, molybdenum, and uranium were the only trace elements analyzed for that had median concentrations greater than 5 micrograms per liter. Volatile organic compounds were detected in 5 of 24 samples. Cis-1,2dichloroethene and 1,1-dichloroethane were the most commonly detected volatile organic compounds (detected in two samples each). Pesticides were detected in 8 of 24 samples. Prometon was the most commonly detected pesticide (detected in 5 of 24 samples). Concentrations of volatile organic compounds and pesticides detected were much smaller than any U.S. Environmental Protection Agency standards that have been established.

Infiltration of surface water and the evaporation or transpiration of this water, which partially is the result of past and present agricultural land use, seem to affect the concentrations of common constituents in shallow ground water in the study area. The small excess chloride in shallow ground water relative to surface water that has been affected by evaporation or transpiration could be due to mixing of shallow ground water with small amounts of precipitation/bulk deposition or septicsystem effluent.

Infiltration of septic-system effluent (residential land use) has affected the shallow ground-water composition in parts of the study area on the basis of the small dissolved oxygen concentrations, large dissolved organic carbon concentrations, and excess chloride. Despite the 
loading of nitrogen to the shallow ground-water system as the result of infiltration of septic-system effluent, the small nitrogen concentrations in shallow ground water probably are due to the small dissolved oxygen concentrations and relatively large dissolved organic carbon concentrations.

The small concentrations and lack of variation of most trace elements indicate that land use has not substantially affected the concentrations of most trace elements in shallow ground water. The relatively large dissolved iron and manganese concentrations in shallow ground water might be the result of the reduced state of shallow ground water, which is due to residential land use. There is no direct evidence that land use has affected radionuclide concentrations or activities.

The presence of synthetic organic compounds (volatile organic compounds and pesticides) in shallow ground water in the study area indicates that human activities have affected shallow ground-water quality. Determining the type of land use associated with the presence of a particular synthetic organic compound in shallow ground water was not possible.

\section{INTRODUCTION}

The U.S. Geological Survey (USGS) began to implement the full-scale National Water-Quality Assessment (NAWQA) Program in 1991. The Rio Grande Valley (fig. 1) was one of the first 20 NAWQA study units selected for study of the status of and trends in the quality of ground water and surface water. One of the goals of the NAWQA Program is to provide a scientific understanding of the natural and human factors affecting the quality of ground water in the Nation. One component of the NAWQA Program, referred to as a land-use study, is to investigate the water quality of recently recharged ground water in areas with relatively homogeneous land use (Gilliom and others, 1995, p. 28-29). An area in and adjacent to Albuquerque, New Mexico, was chosen to assess the relations between urban land use and shallow groundwater quality. The Albuquerque land-use study area (ALS) was limited to an area of dominantly urban land use in the Rio Grande flood plain where depth to ground water generally is less than 25 feet. This area was chosen because it is one of the main urban areas in the Rio Grande Valley NAWQA study unit and urban land use could be affecting ground-water quality because of the relatively shallow depth to water.

\section{Purpose and Scope}

This report describes the quality of shallow ground water and the relations between land use and the quality of that shallow ground water in an urban area in and adjacent to Albuquerque, New Mexico (fig. 1). Water samples were collected from 24 shallow wells for analysis of selected common constituents, nutrients, trace elements, radionuclides, volatile organic compounds (VOC's), and pesticides. The results of the chemical analyses are presented in appendix $\mathrm{A}$ (both appendixes are in the back of the report).

\section{Previous Work}

Many geologic and hydrologic investigations have been conducted in the Albuquerque Basin. Some of the more detailed reports on the geology of the Albuquerque Basin and Albuquerque area were written by Lambert (1968), Kelley (1977), Lozinsky (1988), and Hawley and Haase (1992). Detailed reports on the hydrology of the area were written by Theis (1938), Bjorklund and Maxwell (1961), Titus (1961, 1963), Kernodle and others (1987), and Thom and others (1993). Studies of the water quality and geochemistry of the basin include those of Bjorklund and Maxwell (1961), Anderholm (1987, 1988), Gallaher and others (1987), and Logan (1990).

\section{Base Credits}

All digitally produced page-sized maps in this report are in the Lambert Conformal Conic projection with standard parallels $33^{\circ} 00^{\prime}$ and $45^{\circ} 00^{\prime}$ north latitude and central meridian $106^{\circ} 00^{\prime}$ ' west longitude. Hydrography was modified from 1977-78 USGS digital data, scale 1:100,000, of various dates.

The base for figure 1 was compiled from several sources. Cultural features are from 1992 City of 


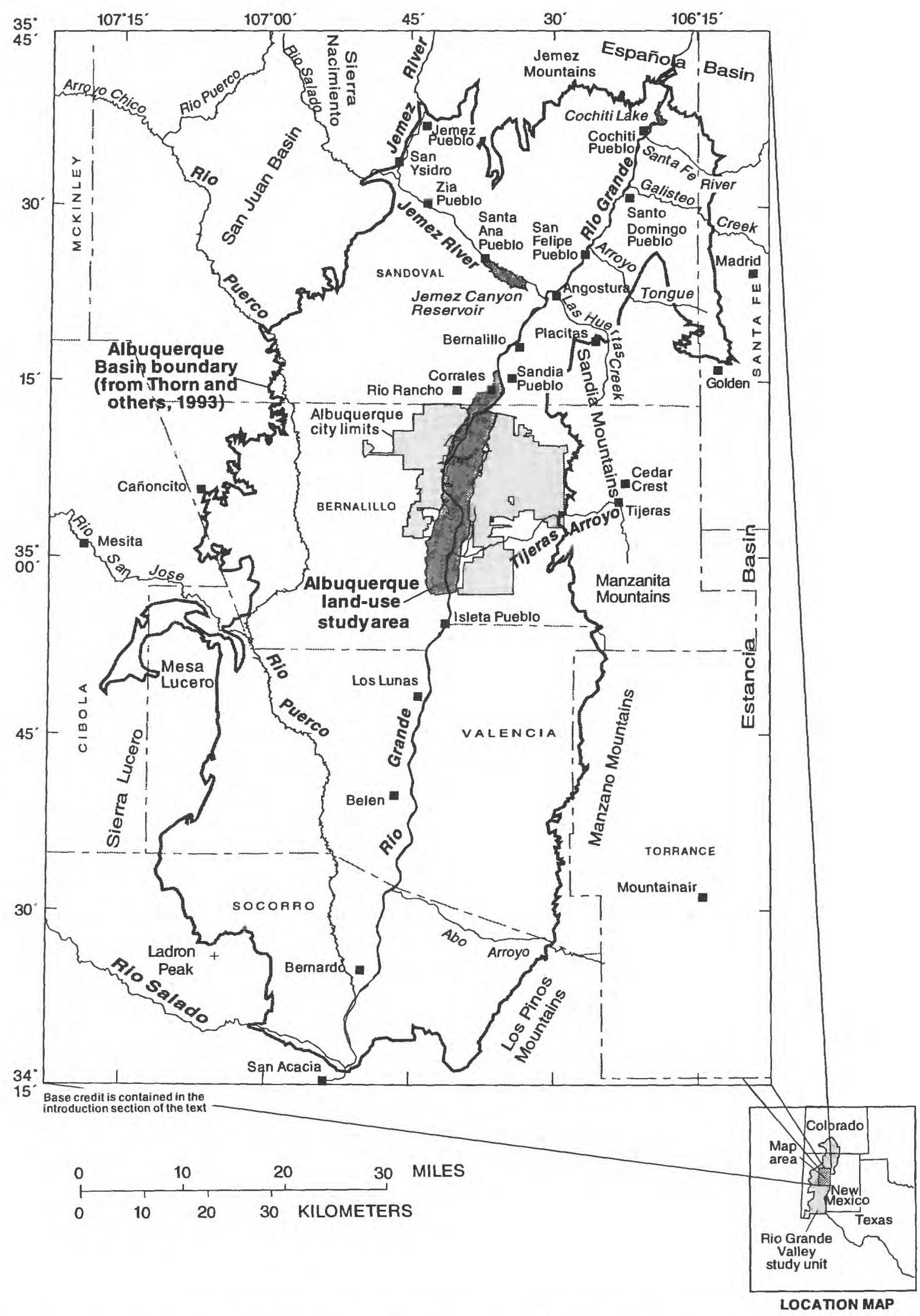

Figure 1.--Location of the Rio Grande Valley National Water-Quality Assessment (NAWQA) study unit, Albuquerque Basin, and Albuquerque land-use study area. 
Albuquerque digital data, scale 1:24,000, and digitized from 1977-78 USGS maps, scale 1:100,000.

The boundary of the Albuquerque land-use study was based on hydrology from 1977-78 USGS digital data, scale $1: 100,000$. The distinction of canals and drains indicated in the data was verified in the field and modified for accuracy.

\section{Acknowledgments}

The residents of the area and personnel from the Middle Rio Grande Conservancy District, City of Albuquerque Parks and Recreation Department, City of Albuquerque Open Space Department, Rio Grande Zoological Park, and City of Albuquerque Environmental Health Department cooperated during the installation and sampling of wells. Their cooperation is greatly appreciated.

\section{DESCRIPTION OF STUDY AREA}

The ALS is in a small part of the Albuquerque Basin (fig. 1) in central New Mexico. The Albuquerque Basin contains thick Cenozoic basin-fill deposits (as thick as 14,000 feet) (Thom and others, 1993, p. 32) and is bounded by mountainous areas along the north, east, and south margins and by an area of low topographic relief on the west margin (fig. 1). Landsurface altitudes are lowest along the Rio Grande, which flows generally north to south through the basin, and highest along the east basin margins. Alluvial fans coalesce at the base of the steep mountainous areas adjacent to the basin, and the land surface slopes gently toward the Rio Grande. The Rio Grande flood plain is entrenched 200 to 500 feet below the piedmont surface that extends from the margins of the basin toward the Rio Grande. The Albuquerque metropolitan area, the largest population center in the Rio Grande Valley NAWQA study unit (about 500,000 in 1990; U.S. Department of Commerce, 1991), is located in the Albuquerque Basin.

The ALS is located in the Rio Grande flood plain or inner valley (area between the outermost irrigation canals) from the Main Corrales Canal south to the intersection of Interstate 25 and the Rio Grande (fig. 2). In this area, land use is mainly urban, although there is intermixed agricultural land use. Depth to water generally is less than 25 feet. The land surface generally is flat in the Rio Grande flood plain. With respect to land use and hydrogeology this area is typical of many of the populated areas in the arid southwestem United States.

The hydrology of the ALS is affected by the hydrology of the Albuquerque Basin. Much of the following discussion focuses on the hydrology of the Albuquerque Basin because understanding the hydrology of the basin is important in order to interpret the hydrology of the ALS.

\section{Climate}

The climate of the Albuquerque Basin is arid to semiarid and is characterized by sunny days, large daily temperature ranges, low humidity, and mean annual potential evapotranspiration exceeding mean annual precipitation (Tuan and others, 1969). The mean annual temperature at the Albuquerque Airport weather station from 1961 to 1990 was $56.2^{\circ} \mathrm{F}$; July is the warmest month and January is the coolest month (U.S. Department of Commerce, 1993). Mean annual precipitation from 1961 to 1990 was about 9 inches (U.S. Department of Commerce, 1993). Mean annual evapotranspiration calculated for Albuquerque is 47.58 inches (Gabin and Lesperance, 1977). There is a precipitation deficit (potential evapotranspiration greater than precipitation) every month of the year; the largest deficit is in July (Gabin and Lesperance, 1977).

\section{Surface-Water System}

The Rio Grande flows north-south through the Albuquerque Basin and is the main drainage for the basin. Major tributaries to the Rio Grande in the Albuquerque Basin are the Jemez River, Rio Puerco, and southernmost Rio Salado (fig. 1). Much of the basin is drained by ephemeral channels (arroyos) that flow only in response to runoff from precipitation.

The canals and drains have a significant effect on the movement of shallow ground water in the flood plain of the Rio Grande. Water for irrigation is diverted from the Rio Grande at several locations in the basin into a system of canals for delivery to irrigated lands, and surface drains maintain ground-water levels below land surface (fig. 2). The irrigation system was constructed in the late 1920's and early 1930's because a large amount of land in the flood plain had become waterlogged (ground-water levels had risen to land surface as the result of infiltration of irrigation water). 


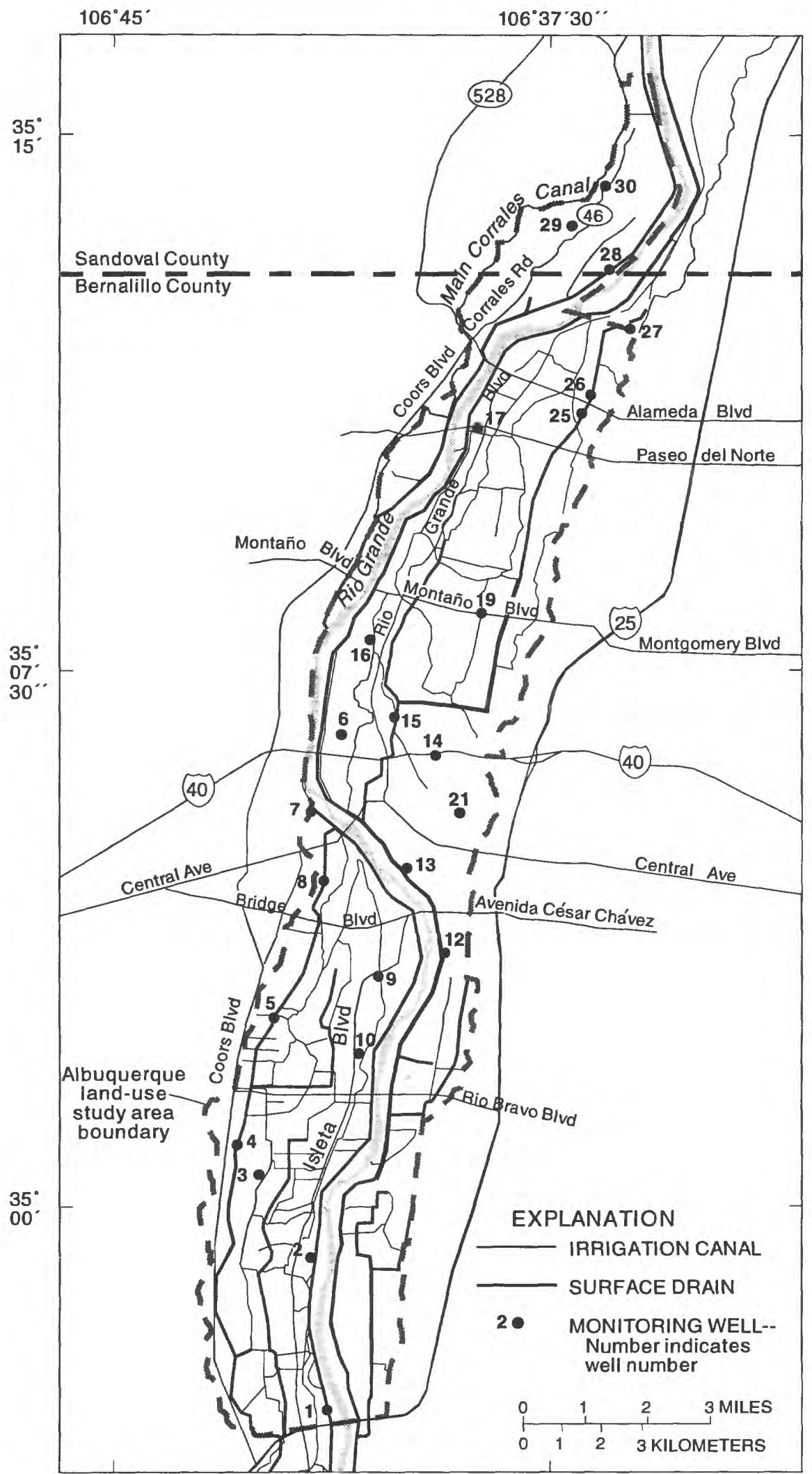

Base credit is contained in the introduction section of the text

Figure 2.--Location of irrigation canals, ditches, surface drains, and monitoring wells. 
Prior to about 1940 much of the land in the ALS was used for irrigated agriculture. Since then much of the land has been urbanized, and some of the smaller canals are no longer used or have been destroyed; however, an existing system is still used to transport water to areas where irrigated agriculture continues. The canals generally are above the zone of saturation and thus are a source of ground-water recharge, as is the irrigation water applied to fields that is not evaporated or consumed by plants. The surface drains are of two types--riverside and interior--and each is used to maintain water levels below land surface (fig. 3). The riverside drains run along each side of the Rio Grande, and the bottoms of these drains are at a level several feet below the riverbed in most of the ALS. The Rio Grande was channelized in the 1920's; since that time the river generally has aggraded, and now the riverbed is several feet above land surface of some areas adjacent to the river. Infiltration of water from the river is intercepted by the riverside drains, preventing waterlogging of these areas. The interior drains were constructed throughout the flood plain. The bottoms of these drains are 5 to 15 feet below land surface, and ground water resulting from infiltration of irrigation water discharges into these drains when the water table is higher than the bottoms of the drains. Irrigation water and storm runoff occasionally are diverted into the interior drains. The interior drains discharge into the riverside drains, which in turn discharge into the Rio Grande.

\section{Ground-Water Hydrology}

The basin-fill deposits, which were deposited in playa lakes, alluvial fans, and river valley environments, are the main aquifer and are referred to as the basin-fill aquifer in the Albuquerque Basin. The sediments in different layers and in different areas of the basin have a large variation in hydraulic conductivity because of the variation of grain size and degree of sorting of these deposits. Thorn and others (1993) presented a detailed discussion of the characteristics of the basin-fill aquifer and the general hydrologic setting of the Albuquerque Basin.

The near-surface part of the basin-fill aquifer (shallow basin-fill aquifer) in the ALS consists of flood-plain and river-channel deposits of the Rio Grande. These deposits consist of interbedded gravel, sand, silt, and clay. Individual beds in these deposits intertongue with other beds and are not laterally continuous; therefore, correlating individual beds over any distance is difficult. Peter (1987, p. 21-23) estimated hydraulic conductivity of the shallow basinfill aquifer to range from 100 to 1,000 feet per day in sands and gravels and calculated a hydraulic conductivity of 0.001 foot per day in a clay and silt unit. As indicated by these values, hydraulic conductivity in the shallow basin-fill aquifer in the ALS varies widely.

The main sources of recharge to the shallow basin-fill aquifer in the ALS are ground-water inflow from areas adjacent to the ALS and infiltration (leakage) of surface water, sewage effluent, and precipitation. Infiltration of surface water includes water from the Rio Grande, irrigation canals, surface drains (in areas where ground-water withdrawals have resulted in lowering of the water table below the bottoms of the drains), and excess applied irrigation water (water applied to fields that is not consumed by crops). Infiltration of sewage effluent includes that from septic systems and leaky sewer pipes.

The main sources of discharge from the shallow basin-fill aquifer in the ALS are ground-water outflow to areas adjacent to the ALS, discharge to riverside and interior drains, ground-water withdrawals, and evapotranspiration. Water from the Rio Grande infiltrates and moves toward the riverside drains. Part of this water discharges to the riverside drains (fig. 3). Ground-water discharge to interior drains results from the rise in water level due to infiltration of water in the canals, infiltration of excess applied irrigation water, and infiltration of septic-system effluent. Discharge to interior drains generally is largest in the late summer and fall when water levels have risen in the shallow basin-fill aquifer as the result of summer irrigation. Discharge to interior drains generally is smallest in the late winter and early spring prior to the start of the irrigation/growing season. Ground-water withdrawals or pumpage vary areally throughout the ALS. Some residences obtain water from municipal water systems, although some of these residences also use shallow irrigation wells to water lawns and gardens. Many residences are not connected to a municipal water system and have individual wells for domestic use. Several large municipal well fields are in the ALS, although most wells in these well fields are deep (greater than 500 feet) and obtain water from the deeper basin-fill deposits (deep basin-fill aquifer). Many of the irrigation wells and private wells are less than 100 feet deep and obtain water from the shallow 


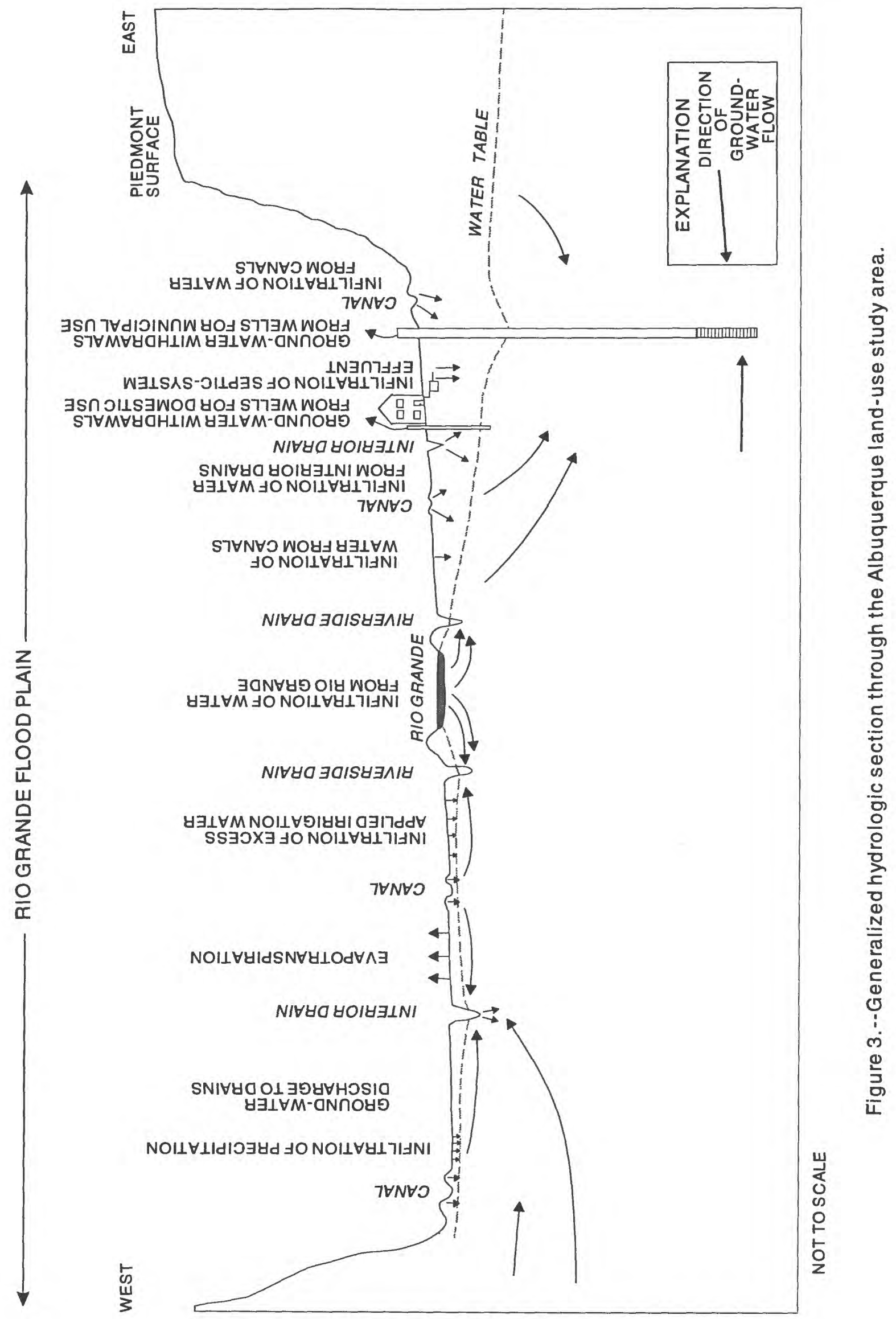


basin-fill aquifer. Evapotranspiration is an important source of discharge of shallow ground water in many areas of the ALS. This process results in an increase in dissolved solids in shallow ground water because plants do not remove significant amounts of dissolved constituents.

Although no water budget estimates have been published for the ALS, a water budget for basin-fill aquifers in the entire Albuquerque Basin for 1994 (Kernodle and others, 1995) indicates that some of the largest inflows to and outflows from the ground-water system are in the flood plain of the Rio Grande. Net inflow to the ground-water system by river, canal, and reservoir leakage was about 200,000 acre-feet per year, recharge along the basin margins and from tributaries to the Rio Grande was about 130,000 acre-feet per year, inflow by infiltration of surface water applied to fields was about 28,000 acre-feet per year, and septic-system infiltration was about 8,000 acre-feet per year. Infiltration of precipitation in the Rio Grande flood plain was not estimated as a separate component in the water budget but was included in the estimate of infiltration of surface water applied to fields. Net outflow from the ground-water system by groundwater discharge to drains was about 219,000 acre-feet per year, ground-water withdrawals were about

171,000 acre-feet per year, and riparian and wetland evapotranspiration was about 90,000 acre-feet per year. Evaporation and transpiration of water applied to fields were not included in the above estimate of evapotranspiration.

The movement of ground water in the shallow basin-fill aquifer of the ALS is complex and variable because of the interaction of the regional ground-water flow system, Rio Grande, irrigation system, groundwater withdrawals, and evapotranspiration. The direction of ground-water flow at a particular location can change during the year depending on the interaction of these factors. Ground-water flow in part of the ALS is dominated by cones of depression in the water table resulting from ground-water withdrawals from the basin-fill deposits east of the ALS. Groundwater levels have declined as much as 160 feet east of the ALS and have resulted in reversals in ground-water flow in part of the ALS (Thorn and others, 1993, p. 63). Prior to withdrawals creating the cones of depression, ground water flowed westward from the mountains on the east side of the Albuquerque Basin toward the Rio Grande. Presently (1993) ground water flows from west to east in part of the ALS (fig. 4). In some parts of the ALS the water table has declined enough to be below the bottom of several interior drains, the riverside drains, and the Rio Grande. Water infiltrates through the beds of these drains and the channel of the Rio Grande to recharge the ground-water system. In areas of the ALS that have not been affected by cones of depression, ground-water flow is dominated by the Rio Grande, riverside drains, canals, infiltration of excess irrigation water and septic-system effluent, interior drains, and withdrawal of ground water from private wells (fig. 3 ).

\section{Land Use and Land Cover}

Land-use and land-cover (hereafter referred to as land-use) information for the ALS was obtained from two sources. The first source, used during the planning stages of the study, was the Geographic Information Retrieval and Analysis System (GIRAS). Land-use data in this system were digitized from 1:250,000- and 1:100,000-scale maps by the USGS. The maps were produced from National Aeronautical and Space Administration high-altitude aerial photographs and from National High Altitude Photography program photographs (U.S. Geological Survey, 1986). The aerial photographs used for land-use information were taken in the mid- to late 1970's. The four main categories of land-use data for the ALS include forest, range, urban, and agricultural. This land-use information was used during the well site-selection phase of the study. After the wells were sampled, more recent and more detailed land-use information was obtained from the Bureau of Reclamation Land Use Trend Analysis Study (LUTA) (Bell and others, 1993). This information was digitized from 1:2,400-scale aerial photographs taken in the late 1980's. The minimum mapping unit used was 1 acre. Land use was categorized using a land-use classification system developed for LUTA. Because this land-use classification system includes many detailed categories of land use, many of the categories were combined to form the categories used in the data analysis presented in this report (fig. 5).

Urban land use represents about 50 percent of the total area in the ALS. The categories of urban land use that were used in the data analysis are commercial/ industrial, residential, parks and golf courses, and urban vacant (fig. 5). Commercial/industrial land use in the ALS represents about 10 percent of the area and ranges from manufacturing to small retail businesses. 


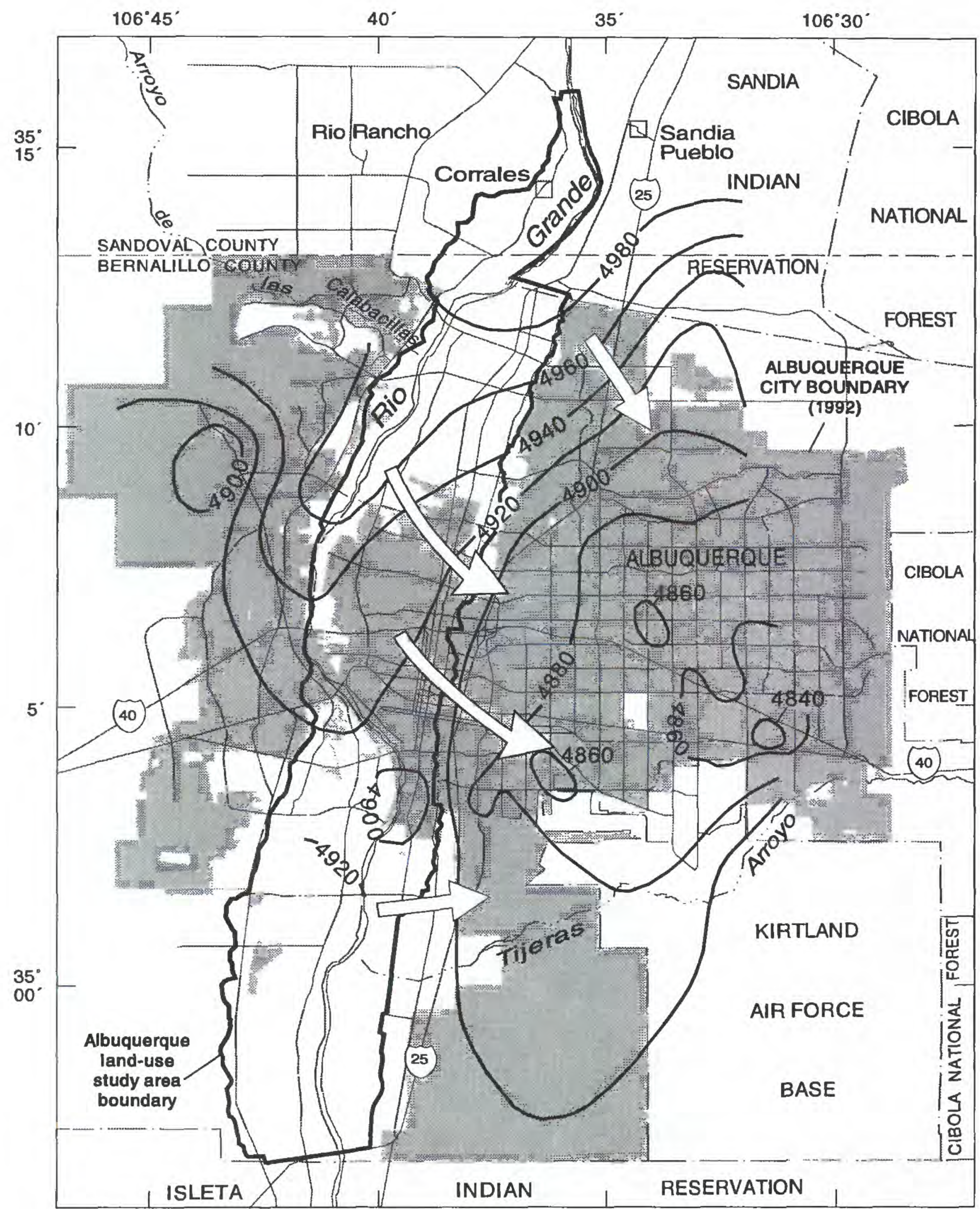

Base compiled from

U.S. Geological Survey digital data, 1:100,000

1977,1978 , and City of Albuquerque digital data,

1:24,000, 1994

EXPLANATION

$\begin{array}{lllll}0 & 2 & 4 & 6 \\ 0 & 2 & 4 & 6 \text { KILOMETERS }\end{array}$ $\begin{aligned} &-4940- \text { WATER-LEVEL CONTOUR-Shows altitude } \\ & \text { of water level, 1992. Interval } 20 \text { feet. } \\ & \text { Datum is sea level }\end{aligned}$

$\longrightarrow$ DIRECTION OF GROUND-WATER FLOW

Figure 4.--Potentiometric surface and direction of ground-water flow in the basin-fill aquifer (from Thorn and others, 1993). 


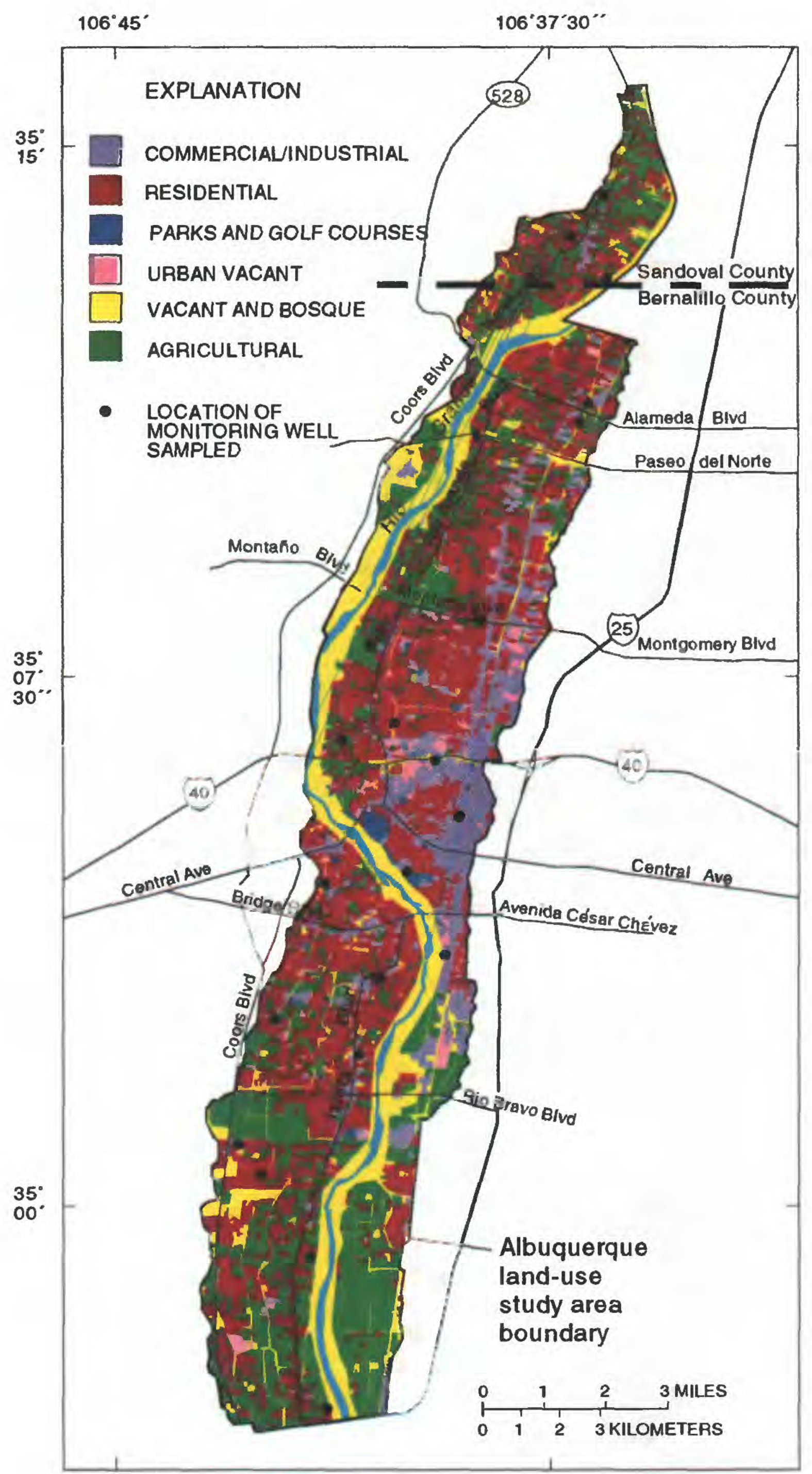

Base credit is contained in the introduction section of the text

Figure 5.--Land use in the Albuquerque land-use study area (data from Bell and others, 1993). 
Residential land use represents about 35 percent of the area and ranges from apartment buildings (highdensity residential) to 1 - or 2-acre lots that contain one residence (low-density residential). Part of the ALS is sewered, although in much of the area each residence has a septic system. In low-density residential areas many individuals still use irrigation ditches to irrigate lawns and gardens. Parks and golf courses, which represent about 1 percent of the area, generally are irrigated with ground water from the municipal water system. Urban vacant land use, which represents about 3 percent of the area, includes small areas of vacant land surrounded by other urban land uses.

The land-use category vacant and bosque, which represents about 23 percent of the area, includes all vacant land not included in urban vacant, the bosque area adjacent to the Rio Grande, and the active channel of the Rio Grande (fig. 5). The bosque consists of areas of dense vegetation such as grasses, shrubs, and cottonwood, salt cedar, and Russian olive trees. The bosque areas have had little or no development with the exception of hiking trails and bridge crossings.

Agricultural land use, which represents about 28 percent of the area, includes orchards; fields of alfalfa, chili, and grapes; and pastures. All agricultural landuse areas are irrigated with surface water or ground water. Many of the irrigation canals and drains, which are associated with agricultural land use, are not delineated in figure 5 and were not included in the agricultural land-use category because of the scale of the LUTA data.

The distribution of different land uses in the ALS is complex (fig. 5). Most of the commercial/industrial land use is east of the Rio Grande between Rio Bravo Boulevard and Paseo del Norte. Most of the vacant and bosque land use is located adjacent to the Rio Grande. Residential and agricultural land use is distributed throughout the ALS. In most of the ALS, agricultural land use is interspersed with residential land use (fig. 5) and neither agricultural nor residential land use is the dominant land use.

Land use in the ALS historically has been continually changing from agricultural to urban. The population of Albuquerque grew slowly prior to about 1940 and most land in the ALS was irrigated and used to grow crops (agricultural land use), although homes were interspersed in the agricultural areas. From about 1940 to 1993 the population in Albuquerque increased rapidly, resulting in a large amount of agricultural land converted to urban or residential land. Thorn and others
(1993, p. 89) indicated that from the early 1980's until 1992 about 14,000 acres of 1and in Bernalillo County were reclassified from agricultural to urban land use. Much of this urbanization was in the ALS. At the time of the study (1993) small areas of agricultural land use were interspersed with urban land use throughout the ALS.

\section{METHODS}

Various methods were used during the datacollection phase of this study to ensure that the data collected were unbiased and that the water samples collected from monitoring wells represented the shallow ground-water quality in the vicinity of the well. The following section describes the procedures used to select the location of the monitoring wells, the procedures used to install and sample the wells, and the results of the quality assurance/quality control data. The procedures used during this study are based on the protocols and procedures developed for the NAWQA Program (Koterba and others, 1995; Lapham and others, 1995).

\section{Well Criteria and Site Selection}

The following criteria were established to determine whether existing wells were suitable for use in this study: (1) well was perforated in only the upper 10 to 15 feet of the zone of saturation; (2) casing material and screens were PVC or stainless steel; (3) well was used only for monitoring; and (4) well was not located in an area of known local contamination. The review of existing well data indicated that new wells would need to be installed because only five existing wells met the above criteria.

Well sites were selected using a computerizedstratified-random-sampling-within-cells technique (Scott, 1990) The computer program first defined a population of approximately 10,000 equally spaced potential sites in the ALS. The program then divided the study area into 30 cells of equal urban land-use area (land-use blocks) using GIRAS land-use data (fig. 6). A primary and three alternate sites were then randomly selected from the potential sites in each land-use block. Each land-use block was numbered, and the well sampled in each block was given a well number that corresponds with the block (figs. 6 and 2; appendix A). If an existing well met the selection criteria in a 


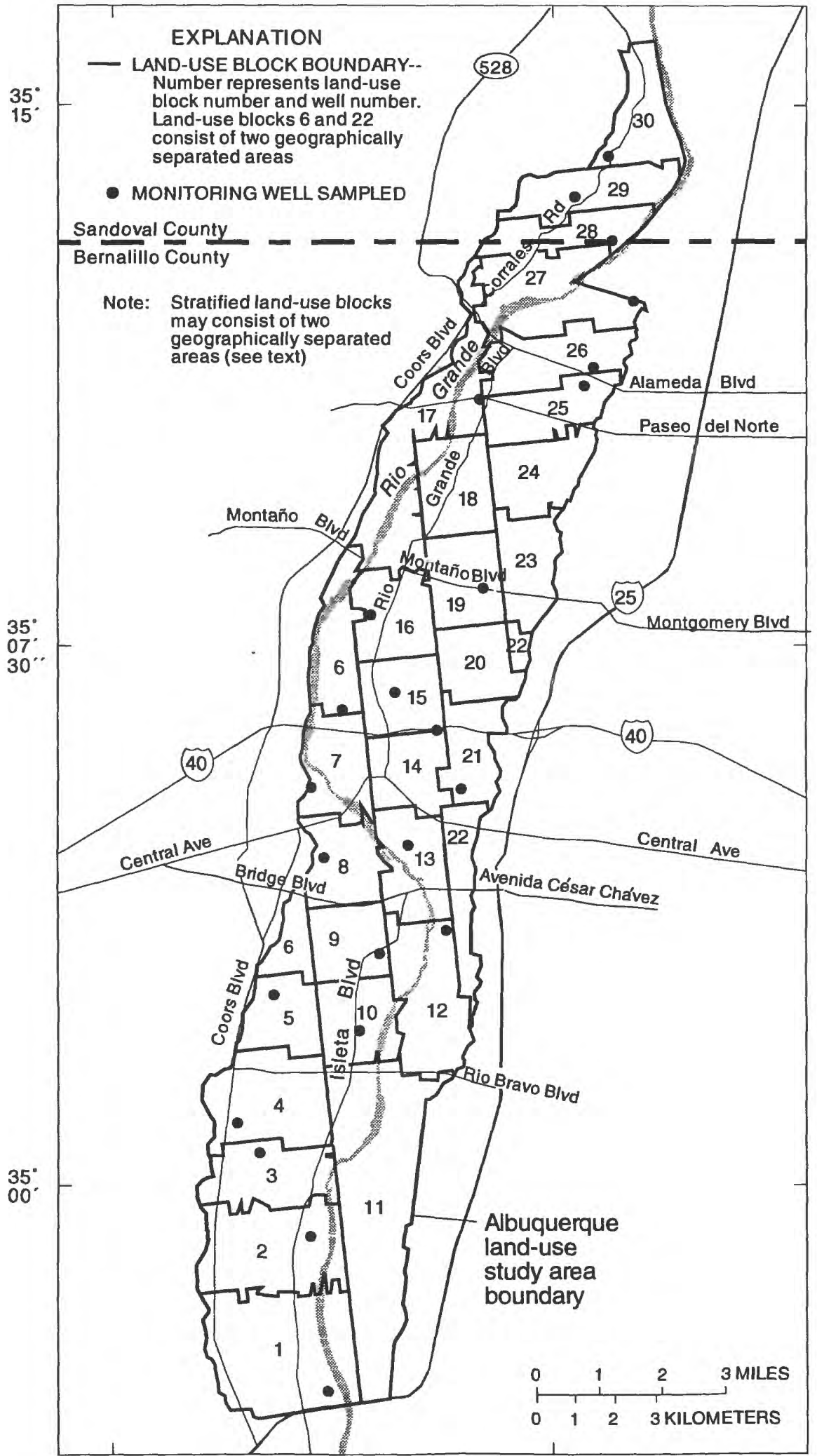

Base credit is contained in the introduction section of the text

Figure 6.--Location of land-use blocks and monitoring wells sampled. 
particular block, that well was selected for sampling. In blocks where no existing monitoring wells were found, field personnel obtained permission to install a monitoring well on private property. If an acceptable site could not be found within 600 feet of the primary site, each succeeding alternate site was visited until an acceptable site was located. The criteria used to determine an acceptable site were (1) land owner was willing to let the USGS install the well and maintain access for 10 years; (2) no utility lines were at the site; and (3) it was possible to get the auger rig to the site. In four cases an acceptable site could not be found before drilling operations were terminated. In two cases, the wells installed were completed above the water table because of limitations of the auger rig.

\section{Well Installation}

The monitoring wells were constructed in June 1993 using a trailer-mounted, hollow-stem auger that drilled a 6.62-inch hole. Wooden plugs were inserted in the open end of the bit and the holes were augured to a depth approximately 10 feet below the water table. The driller determined the location of the water table on the basis of drilling rate and well cuttings. The wells were constructed using 10 feet of well screen that was placed opposite the top 10 feet of the zone of saturation. Twoinch inside-diameter PVC casing and well screen (0.01-inch slot size) were removed from the protective plastic bags in which they were packed by the manufacturer, screwed together by field personnel, and lowered into the center of the hollow auger flights. All components of the well casing were handled by personnel wearing clean rubber gloves. The wooden plugs were popped out of the bottom of the bit using the assembled casing string, and the augers were pulled up out of the hole. The hole generally collapsed to a level above the top of the screens; if it did not, packaged silica sand was added to fill the annular space to above the top of the screens. Bentonite pellets were added to create a seal 2 to 3 feet above the sand pack and screens, and the hole was backfilled with drill cuttings to within 1 foot of land surface. A 5-inch-diameter by 3-foot-long steel well protector was installed over the PVC casing and a concrete pad was installed at the site. The auger flights were then steam cleaned to prevent cross contamination between wells.

The wells were developed within 3 weeks after installation using a PVC bailer and a pump. About 100 gallons of water were bailed from each well to remove sediment from the bottom of the well and to surge the well. Each well was then pumped until the water discharging from it was free of sediment.

\section{Water Sampling}

In July, August, and September 1993, 24 monitoring wells were sampled (fig. 6) for selected common constituents, nutrients, dissolved organic carbon, trace elements, radionuclides, VOC's, and pesticides (table 1). Samples were analyzed for pesticides using two different techniques and are grouped in table 1 to reflect the technique used for each particular pesticide.

The wells were sampled using a 1.8-inch submersible pump that was lowered into the wells and plumbed to the sampling van using Teflon tubing. The wells were pumped to remove three casing volumes of water from the well prior to any field measurements. Field properties, including temperature, specific conductance, $\mathrm{pH}$, dissolved oxygen, and turbidity, were measured at 5-minute intervals until the chemistry of the discharge water stabilized. The stability criteria used were (1) less than 0.5 -degreeCelsius variation in temperature; (2) less than 10percent variation in specific conductance; (3) less than 0.1 -unit variation in $\mathrm{pH}$; (4) less than 0.3 -milligramper-liter $(\mathrm{mg} / \mathrm{L})$ variation in dissolved oxygen; and (5) less than 5-turbidity-unit variation in turbidity. After the water met stability criteria, it was diverted to the sampling chamber (a PVC frame enclosed in a plastic bag) located in the sampling van where all samples, with the exception of radon-222, were collected. Radon-222 samples were collected outside the sampling van using a special collection unit (Koterba and others, 1995). Pesticide samples were filtered using an aluminum filter plate and a 0.7 -micron-pore-size glass baked filter. Inorganic samples were filtered using an acrylic filter plate and a 0.45 -micron-pore-size filter. Samples for dissolved cations and trace elements were acidified to a pH less than 2 with trace-element-grade nitric acid. Dissolved organic carbon samples were filtered using a stainless steel filtering apparatus and a 0.45-micron-pore-size silver filter. All filtering, with the exception of dissolved organic carbon samples, was done inside the sampling chamber.

After sample collection, the pump and tubing were decontaminated by pumping and circulating a 0.1 -percent solution of liquinox through the tubing for 10 minutes. About 3 gallons of deionized water were 


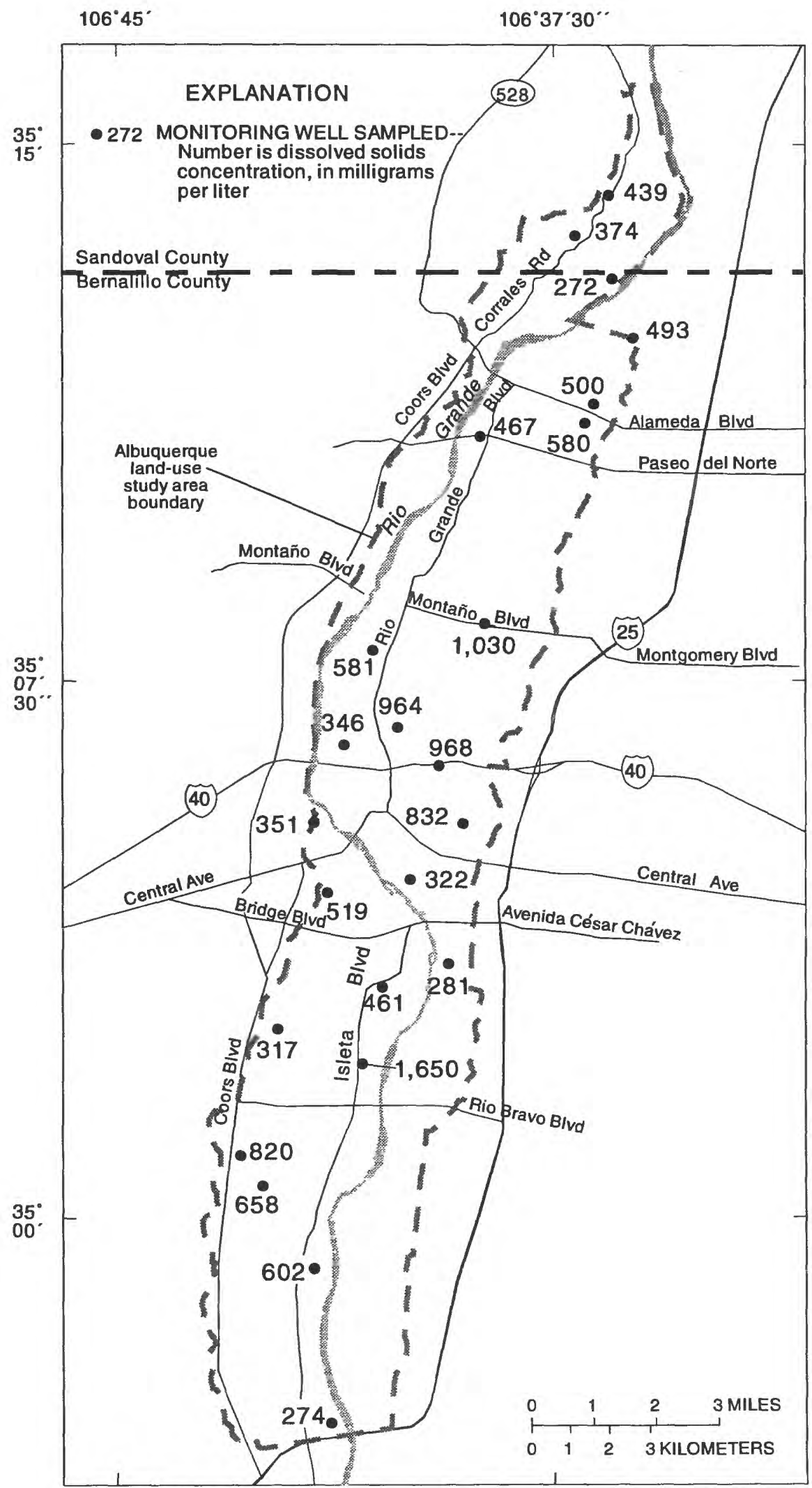

Base credit is contained in the introduction section of the text

Figure 7.--Dissolved solids concentration in shallow ground water in the Albuquerque land-use study area. 
Table 1.--Analyte constituents and minimum reporting levels or method detection limits

[mg/L, milligrams per liter; $\mu \mathrm{g} / \mathrm{L}$, micrograms per liter; $\mathrm{pCi} / \mathrm{L}$, picocuries per liter; *, minimum reporting level varies in some samples.

Pesticides listed in Group A extracted by C-18 solid-phase extraction cartridge and analyzed by gas chromatography/mass spectrometric detector. Pesticides listed in Group B extracted by Carbopak-B solid-phase extraction cartridge and analyzed by highperformance liquid chromatography. Method detection limit is minimum concentration at which the pesticide can be identified, measured, and reported with 99-percent confidence that the concentration is greater than zero (Zaugg and others, 1995).

All pesticides reported in micrograms per liter]

\begin{tabular}{lc}
\hline & Common constituents \\
\hline Constituent & Minimum reporting leve $(\mathrm{mg} / \mathrm{L})$ \\
\hline Calcium & 0.02 \\
Magnesium & 0.01 \\
Sodium & 0.2 \\
Potassium & 0.1 \\
Bicarbonate & 0.1 \\
Carbonate & 0.1 \\
Sulfate & 0.1 \\
Chloride & 0.1 \\
Fluoride & 0.1 \\
Bromide & 0.01 \\
Silica & 0.01
\end{tabular}

\begin{tabular}{cc}
\hline \multicolumn{2}{c}{ Nutrients and dissolved organic carbon } \\
\hline Constituent & Minimum reporting level $(\mathrm{mg} / \mathrm{L})$ \\
\hline
\end{tabular}

\begin{tabular}{lc} 
& Volatile organic compounds \\
\hline Constituent & Minimum reporting level $(\mu \mathrm{g} / \mathrm{L})$ \\
\hline
\end{tabular}

Benzene 0.2

Bromobenzene $\quad 0.2$

Bromochloromethane $\quad 0.2$

Bromoform 0.2

Carbon tetrachloride $\quad 0.2$

Chlorobenzene $\quad 0.2$

Chlorodibromomethane $\quad 0.2$

Chloroethane $\quad 0.2$

Chloroform 0.2

Cis-1,2-dichloroethene $\quad 0.2$

Cis-1,3-dichloropropene $\quad 0.2$

Dibromochloropropane $\quad 1.0$

1,2-dibromoethane $\quad 0.2$

Dibromomethane 0.2

1,3-dichlorobenzene $\quad 0.2$

1,4-dichlorobenzene $\quad 0.2$

Dichlorobromomethane $\quad 0.2$

$\begin{array}{llll}\text { Nitrite plus nitrate as nitrogen } & 0.05 & \text { Dichlorodifluoromethane } & 0.2 \\ \text { Ammonia as nitrogen } & 0.015 & 1,1 \text {-dichloroethane } & 0.2\end{array}$

Ammonia as nitrogen 0.015

Ammonia plus organic nitrogen $\quad 0.2$ as nitrogen

$\begin{array}{ll}\text { Phosphorus } & 0.01\end{array}$

Orthophosphorus $\quad 0.01$

Dissolved organic carbon $\quad 0.1$

\begin{tabular}{lc}
\hline & Trace elements \\
\hline Constituent & Minimum reporting level $(\mu \mathrm{g} / \mathrm{L})$ \\
\hline
\end{tabular}

1,2-dichloroethane $\quad 0.2$

1,1-dichloroethylene $\quad 0.2$

1,2-dichloropropane $\quad 0.2$

1,3-dichloropropane $\quad 0.2$

2,2-dichloropropane $\quad 0.2$

1,1-dichloropropene $\quad 0.2$

Ethylbenzene $\quad 0.2$

Freon-113 0.2

Hexachlorobutadiene $\quad 0.2$

Isopropylbenzene $\quad 0.2$

Mesitylene $\quad 0.2$

Methylbromide $\quad 0.2$

Methylchloride $\quad 0.2$

Methylene chloride $\quad 0.2$

Methyltertbutylether (MTBE) $\quad 0.2$

Napthalene $\quad 0.2$

N-butylbenzene $\quad 0.2$

$\mathrm{N}$-propylbenzene $\quad 0.2$

O-chlorobenzene $\quad 0.2$

O-chlorotoluene $\quad 0.2$

P-chlorotoluene $\quad 0.2$

P-iso-propyltoluene $\quad 0.2$

Pseudocumene $\quad 0.2$

Sec-butylbenzene $\quad 0.2$

Styrene 0.2

Tertbutylbenzene $\quad 0.2$

1,1,1,2-tetrachloroethane $\quad 0.2$

1,1,2,2-tetrachloroethane $\quad 0.2$

Tetrachloroethylene $\quad 0.2$

Toluene $\quad 0.2$

1,2-transdichloroethene $\quad 0.2$

Trans-1,3-dichloropropene $\quad 0.2$

1,2,3-trichlorobenzene $\quad 0.2$

1,2,4-trichlorobenzene $\quad 0.2$

1,1,1-trichloroethane $\quad 0.2$

1,1,2-trichloroethane $\quad 0.2$

Trichloroethylene $\quad 0.2$

Trichlorofluoromethane $\quad 0.2$

1,2,3-tricloropropane $\quad 0.2$

Vinyl chloride $\quad 0.2$

$\begin{array}{ll}\text { Xylene } & 0.2\end{array}$ 
Table 1.--Analyte constituents and minimum reporting levels or method detection limits-Concluded

\begin{tabular}{|c|c|c|c|}
\hline \multicolumn{4}{|c|}{ Pesticides } \\
\hline \multicolumn{2}{|c|}{ Group A } & \multicolumn{2}{|c|}{ Group B } \\
\hline Name & Method detection limit & Name & Method detection limit \\
\hline Acetochlor & 0.002 & Acifluorfen & 0.035 \\
\hline Alachlor & 0.002 & Aldicarb & 0.016 \\
\hline Alpha HCH & 0.002 & Aldicarb sulfone & 0.016 \\
\hline Atrazine & 0.001 & Aldicarb sulfoxide & 0.021 \\
\hline Benfluralin & 0.002 & Amiben & 0.011 \\
\hline Butylate & 0.002 & Bentazon & 0.014 \\
\hline Carbaryl & 0.003 & Bromacil & 0.035 \\
\hline Carbofuran & 0.003 & Bromoxynil & 0.035 \\
\hline Chlorpyrifos & 0.004 & Carbaryl & 0.008 \\
\hline Cyanazine & 0.004 & Carbofuran & 0.028 \\
\hline DCPA & 0.002 & Chlorothalonil & 0.035 \\
\hline p,p'-DDE & 0.006 & Clopyralid & 0.050 \\
\hline Deethyl atrazine & 0.002 & 2,4-D & 0.035 \\
\hline Diazinon & 0.002 & Dacthal mono-acid & 0.017 \\
\hline Dieldrin & 0.001 & $2,4-\mathrm{DB}$ & 0.035 \\
\hline 2,6-diethylaniline & 0.003 & Dicamba & 0.035 \\
\hline Dimethoate & 0.024 & Dichlobenil & 0.020 \\
\hline Disulfoton & 0.017 & Dichlorprop & 0.032 \\
\hline EPTC & 0.002 & Dinoseb & 0.035 \\
\hline Ethalfluralin & 0.004 & Diuron & 0.020 \\
\hline Ethoprop & 0.003 & Esfenvalerate & 0.019 \\
\hline Fonofos & 0.003 & Fenuron & 0.013 \\
\hline Lindane & 0.004 & Fluometuron & 0.035 \\
\hline Linuron & 0.002 & 3-hydroxycarbofuran & 0.014 \\
\hline Malathion & 0.005 & Linuron & 0.018 \\
\hline Methyl azinphos & 0.001 & MCPA & 0.050 \\
\hline Methyl parathion & 0.006 & MCPB & 0.035 \\
\hline Metolachlor & 0.002 & Methiocarb & 0.026 \\
\hline Metribuzin & 0.004 & Methomyl & 0.017 \\
\hline Molinate & 0.004 & 1-naphthol & 0.007 \\
\hline Napropamide & 0.003 & Neburon & 0.015 \\
\hline Parathion & 0.004 & Norflurazon & 0.024 \\
\hline Pebulate & 0.004 & Ocresol & 0.035 \\
\hline Pendimethalin & 0.004 & Oryzalin & 0.019 \\
\hline Permethrin-cis & 0.005 & Oxamyl & 0.018 \\
\hline Phorate & 0.002 & Picloram & 0.050 \\
\hline Prometon & 0.018 & Propham & 0.035 \\
\hline Pronamide & 0.003 & Propoxur & 0.035 \\
\hline Propachlor & 0.007 & Silvex & 0.021 \\
\hline Propargite & 0.013 & $2,4,5-\mathrm{T}$ & 0.035 \\
\hline Propanil & 0.004 & Triclopyr & 0.050 \\
\hline Simazine & 0.005 & & \\
\hline Tebuthiuron & 0.010 & & \\
\hline Terbacil & 0.007 & & \\
\hline Terbufos & 0.013 & & \\
\hline Thiobencarb & 0.002 & & \\
\hline Triallate & 0.001 & & \\
\hline Trifluralin & 0.002 & & \\
\hline
\end{tabular}


then pumped through the tubing. The pump and tubing were then dismantled and stored in clean plastic bags. The filter plates used for filtering pesticide samples were disassembled and washed with a 0.2 -percent liquinox solution, rinsed with tap water, rinsed with deionized water, and rinsed with pesticide-grade methanol. After the filter plates had air dried, they were assembled without a filter, wrapped in aluminum foil, and stored in plastic bags. The acrylic filter plates used for inorganic samples were disassembled and washed with a 0.1-percent liquinox solution, rinsed with tap water, rinsed with deionized water, and reassembled without a filter. A 1.0-percent hydrochloric acid solution was then pumped through the filter units, followed by deionized water pumped through the units. The units were then drained and stored in clean plastic bags. The dissolved organic carbon filter unit was disassembled and rinsed with organic-free water, air dried, reassembled, and wrapped in aluminum foil.

\section{National Water Quality Laboratory Methods}

The USGS National Water Quality Laboratory (NWQL) analyzed all samples. Fishman (1993) discussed the methods used for the analysis of common ions and nutrients. Trace elements were analyzed by inductively coupled plasma/mass spectrometer techniques (Faires, 1993). Thatcher and others (1977) reported on gross alpha and gross beta analytical methods. Radon-222 was analyzed by liquid scintillation counting. Rose and Shroeder (1995) outlined methods used for the analysis of VOC's, and Zaugg and others (1995) and Werner and others (1996) outlined methods used for analysis of pesticides. The NWQL has a quality assurance program in place (Friedman and Erdmann , 1982; Pritt and Raese, 1992), but the specifics of this program are not addressed in this report.

The minimum reporting level (MRL) or the method detection limit (MDL) for a given constituent (table 1) generally is based on the analytical methods used. The MRL is the lowest measured concentration of a constituent that may be reliably reported using a given analytical method (Timme, 1995, p. 92). The MRL is used when documentation for an analytical method is not available. The MRL is increased in samples where analytical interferences affect the analytical method. Due to unpredictable matrix effects on detection limits, the MRL is set somewhat higher than the MDL. The MDL's included in table 1 were defined and determined by personnel at the NWQL (Zaugg and others, 1995; Peter Rogerson, National Water Quality Laboratory, written commun., 1996). The MDL is the minimum concentration of a particular analyte that can be identified, measured, and reported with 99-percent confidence that the analyte concentration is greater than zero (Zaugg and others, 1995). When, as in some analyses, a particular pesticide was identified in a sample at a concentration below the MDL, the concentration was reported as estimated.

\section{Quality Assurance /Quality Control of Data}

A quality assurance program ensured that the sampling procedures and characteristics of the water sampled (matrix bias or interferences) did not result in poor-quality data. Blank samples, duplicate samples, and spike samples were collected as part of the quality control used in this study. The results of the quality assurance program that are presented are a compilation of all quality assurance samples collected during July through September 1993 (includes samples collected as part of another study) (table 2 and appendix B). The same procedures were used to collect samples and the same personnel collected all samples from July to September so that any problems with data that resulted from sampling procedures would be evident in the quality assurance data.

Six field blanks were collected and sent to the NWQL from July through September 1993 to ensure that chemical constituents were not being introduced to samples as the result of the sampling procedures used. Field blanks were collected by pumping inorganic- and organic-free water from a glass stand pipe with the submersible pump through the tubing and into the sampling chamber where the bottles were filled or the water was filtered and put into bottles. The blank samples were then processed (acidified, if appropriate) and shipped to the NWQL along with the ground-water samples.

Concentrations of constituents in the field-blank samples greater than the MRL or MDL and in the same range as concentrations measured in the ground-water samples suggest that concentrations of these constituents in the ground-water samples are questionable because it cannot be determined whether 
Table 2.--Constituents detected in blanks, range of concentrations in blank samples, and range of concentrations in shallow ground water

[MRL, minimum reporting level; MDL, method detection limit; $\mu \mathrm{S} / \mathrm{cm}$, microsiemens per centimeter at 25 degrees Celsius; $\mathrm{mg} / \mathrm{L}$, milligrams per liter; $\mu \mathrm{g} / \mathrm{L}$, micrograms per liter; E, estimated; <, less than]

\begin{tabular}{|c|c|c|c|c|}
\hline $\begin{array}{l}\text { Constituent } \\
\text { (and unit of measurement) }\end{array}$ & MRL or MDL & $\begin{array}{c}\text { Number of } \\
\text { samples } \\
\text { above MRL } \\
\text { or MDL }\end{array}$ & $\begin{array}{c}\text { Range of } \\
\text { concentrations } \\
\text { in blank } \\
\text { samples }\end{array}$ & $\begin{array}{l}\text { Range of } \\
\text { concentrations } \\
\text { in shallow } \\
\text { ground water }\end{array}$ \\
\hline Specific conductance $(\mu \mathrm{S} / \mathrm{cm})$ & 1.0 & 6 & $2-3$ & $400-2,400$ \\
\hline Calcium (mg/L) & 0.02 & 1 & 0.03 & $41-210$ \\
\hline Alkalinity $\left(\mathrm{mg} / \mathrm{L}\right.$ as $\left.\mathrm{CaCO}_{3}\right)$ & 1.0 & 4 & $1.3-4.3$ & $121-482$ \\
\hline Chloride (mg/L) & 0.1 & 2 & $0.1-0.3$ & $<0.1-140$ \\
\hline Sulfate $(\mathrm{mg} / \mathrm{L})$ & 0.1 & 5 & $0.2-0.4$ & $59-610$ \\
\hline Silica $\left(\mathrm{mg} / \mathrm{L}\right.$ as $\left.\mathrm{SiO}_{2}\right)$ & 0.01 & 6 & $0.02-0.2$ & $22-59$ \\
\hline Bromide (mg/L) & 0.01 & 1 & 0.01 & $<0.01-0.47$ \\
\hline Ammonia (mg/L as N) & 0.015 & 6 & $0.01-0.03$ & $<0.01-0.27$ \\
\hline Phosphorus (mg/L as P) & 0.01 & 2 & 0.01 & $<0.01-0.40$ \\
\hline Orthophosphorus (mg/L as P) & 0.01 & 1 & 0.01 & $<0.01-0.39$ \\
\hline Aluminum $(\mu \mathrm{g} / \mathrm{L})$ & 1 & 6 & $2-4$ & $1-10$ \\
\hline Cadmium $(\mu \mathrm{g} / \mathrm{L})$ & 1 & 1 & 1 & $<1-2$ \\
\hline Chromium $(\mu \mathrm{g} / \mathrm{L})$ & 1 & 1 & 2 & $<1-5$ \\
\hline Copper $(\mu g / L)$ & 1 & 2 & 1 & $<1-8$ \\
\hline Iron $(\mu \mathrm{g} / \mathrm{L})$ & 3 & 1 & 8 & $4-3,800$ \\
\hline Nickel $(\mu \mathrm{g} / \mathrm{L})$ & 1 & 3 & 2 & $<1-26$ \\
\hline $\operatorname{Zinc}(\mu \mathrm{g} / \mathrm{L})$ & 1 & 6 & $3-10$ & $2-12$ \\
\hline Dissolved organic carbon $(\mathrm{mg} / \mathrm{L})$ & 0.1 & 4 & $0.1-0.3$ & $1.2-5.8$ \\
\hline Methylene chloride $(\mu \mathrm{g} / \mathrm{L})$ & 0.2 & 4 & $0.4-4.0$ & $<0.2$ \\
\hline Benfluralin $(\mu \mathrm{g} / \mathrm{L})$ & 0.009 & 1 & E0.003 & $<0.009$ \\
\hline Permethrin-cis $(\mu \mathrm{g} / \mathrm{L})$ & 0.016 & 1 & E0.006 & $<0.016$ \\
\hline Triallate $(\mu \mathrm{g} / \mathrm{L})$ & 0.004 & 1 & E0.001 & $<0.004$ \\
\hline
\end{tabular}


the concentrations are caused by sampling procedures or if these constituents actually are present in ground water. Concentrations of constituents in the field-blank samples at or near the MRL or MDL and much smaller than concentrations in the ground-water samples indicate that small differences in concentrations for a particular constituent in different ground-water samples may not be real, but instead may be due to sampling and analytical procedures. Constituents not discussed below were not detected in any of the fieldblank samples; therefore, these constituents were not measurably affected by sampling procedures. Most constituents in field-blank samples were measured at concentrations less than the MRL or MDL (table 2); therefore, the sampling procedures probably did not introduce measurable contamination for most constituents. The following constituents, however, were affected by sampling procedures (table 2 ). Calcium was found in one field-blank sample $(0.03 \mathrm{mg} / \mathrm{L})$, alkalinity in four field-blank samples (1.3 to $4.3 \mathrm{mg} / \mathrm{L}$ as $\mathrm{CaCO}_{3}$ ), chloride in two field-blank samples $(0.1$ and $0.3 \mathrm{mg} / \mathrm{L})$, sulfate in five field-blank samples $(0.2$ to $0.4 \mathrm{mg} / \mathrm{L})$, and silica in all six fieldblank samples $(0.02$ to $0.2 \mathrm{mg} / \mathrm{L})$. Ammonia, at a concentration ranging from 0.01 to $0.03 \mathrm{mg} / \mathrm{L}$ as $\mathrm{N}$, was found in all field-blank samples. These ammonia concentrations are in the same range as those in about one-half the ground-water samples. Dissolved phosphorus was found in two field-blank samples at a concentration of $0.01 \mathrm{mg} / \mathrm{L}$ as $\mathrm{P}$, and dissolved orthophosphorus was found in one field-blank sample at a concentration of $0.01 \mathrm{mg} / \mathrm{L}$ as $\mathrm{P}$. Trace elements found in the blank samples include aluminum in all six samples ( 2 to 4 micrograms per liter $(\mu \mathrm{g} / \mathrm{L})$ ), cadmium in one sample $(1 \mu \mathrm{g} / \mathrm{L})$, chromium in one sample (2 $\mu \mathrm{g} / \mathrm{L})$, copper in two samples $(1 \mu \mathrm{g} / \mathrm{L})$, iron in one sample $(8 \mu \mathrm{g} / \mathrm{L})$, nickel in three samples $(2 \mu \mathrm{g} / \mathrm{L})$, and zinc in all six samples ( 3 to $10 \mu \mathrm{g} / \mathrm{L}$ ). The concentrations of zinc in the blank samples are in the same range as those in the ground-water samples. Dissolved organic carbon was found in four field-blank samples at concentrations ranging from 0.1 to 0.3 $\mathrm{mg} / \mathrm{L}$. Methylene chloride was found in four of the field-blank samples $(0.4$ to $4.0 \mu \mathrm{g} / \mathrm{L})$, and the following pesticides were found once in a blank sample: benfluralin (an estimated $0.003 \mu \mathrm{g} / \mathrm{L}$ ), permethrin-cis (an estimated $0.006 \mu \mathrm{g} / \mathrm{L}$ ), and triallate (an estimated $0.001 \mu \mathrm{g} / \mathrm{L}$. Methylene chloride, benfluralin, permethrin-cis, and triallate were not found in any ground-water samples.
Replicate samples were sent to the NWQL to determine precision for an individual sample site resulting from sampling procedures, laboratory measurement variability, or changes in the chemical composition of water withdrawn from the well during sampling. Comparison of the analytical results of the replicate samples indicates a good agreement between measured concentrations (most values are within 10 percent) (appendix B-1).

Surrogate compounds were added to all groundwater samples that were analyzed for pesticides, and spikes (field and laboratory) were added to selected ground-water samples to determine the precision and accuracy of the analyte recovery in the sample matrix and the appropriateness of the analytical methods used for selected organic compounds. Surrogate recoveries for the Group A pesticide analyses ranged from 60 to 120 percent, indicating that the method was appropriate and matrix effects were minimal for the surrogate compounds (appendix A). Surrogate recoveries for Group B pesticides ranged from 0 to 120 percent. These relatively low surrogate recoveries for Group B pesticides are not necessarily indicative of poor performance of the method because one of the surrogates did not perform as expected and was deleted from the analysis (National Water-Quality Assessment/National Water Quality Laboratory Quality Assurance Committee, written commun., 1995). Median recoveries for spiked compounds (VOC's) ranged from 54 to 80 percent for 18 samples (6 laboratory spikes, 6 field spikes, and 6 field-spike replicates) (appendix B-2). Median recoveries for spiked compounds for the Group A pesticides ranged from 62 to 140 percent with the exception of deethyl atrazine (median 20 percent), dimethoate (median less than 20 percent), permethrin-cis (median 21 percent), and propargite (median 200 percent) (appendix B-3). NWQL personnel said that they generally have poor recoveries for the first three compounds and that an interference results in large recoveries for the last compound (Steve Zaugg, National Water Quality Laboratory, oral commun., 1994). None of these compounds were found in the ground-water samples. Spike recovery data for Group B pesticides are not presented because only two spike samples were collected during the sampling. All spike data for Group B pesticides that were collected from 1993 to 1995 were evaluated, and the spike recoveries were found generally to be less than the Group A pesticide spike recoveries (National Water-Quality 
Assessment/National Water Quality Laboratory Quality Assurance Committee, written commun., 1995). The smaller spike recoveries for Group B pesticides could result in failure of the method to detect compounds present in the samples at concentrations larger than the MDL.

\section{SHALLOW GROUND-WATER QUALITY}

The chemical composition of shallow ground water in the ALS varies considerably. The dissolved solids concentration in water from the sampled monitoring wells ranged from 272 to $1,650 \mathrm{mg} / \mathrm{L}$ with a 50 th percentile (median) of $496.5 \mathrm{mg} / \mathrm{L}$ (table 3 ). The U.S. Environmental Protection Agency (EPA) has set a secondary maximum contaminant level (SMCL) of $500 \mathrm{mg} / \mathrm{L}$ for dissolved solids (U.S. Environmental Protection Agency, 1996). SMCL's are standards set for aesthetic purposes and are not health based. Eleven of the 24 samples exceeded the SMCL for dissolved solids (appendix A). From about Central Avenue and north, the dissolved solids concentration of shallow ground water was smaller near the Rio Grande and larger in water from wells farther away from the Rio Grande (fig. 7). The dissolved solids concentration in water from the three wells west of the Rio Grande in the northern part of the ALS were smaller than the median concentration (fig. 7). Calcium ranged from about 50 to 70 percent of the common cations (calcium, sodium plus potassium, and magnesium) and generally was the dominant cation in shallow ground water (fig. 8). The percentage of magnesium was relatively constant in shallow ground water (10-20 percent). Bicarbonate ranged from about 40 to 70 percent of the common anions (bicarbonate, sulfate, and chloride), and the percentage of chloride was relatively constant in shallow ground water (fig. 8). Bicarbonate was the dominant anion in most of the samples, although the percentage of sulfate was greater than the percentage of bicarbonate in 5 of the 24 samples. The percentage of different cations in the samples was not related to dissolved solids concentration, although the percentage of sulfate increased with increasing dissolved solids concentration (fig. 8). In general, the water sampled had little variation in relative percentages of specific cations and anions, considering the range of dissolved solids concentration (fig. 8). The SMCL of $250 \mathrm{mg} / \mathrm{L}$ for sulfate was exceeded in 5 of the 24 samples (appendix A). Fluoride concentrations ranged from 0.2 to $1.2 \mathrm{mg} / \mathrm{L}$, and silica concentrations ranged from 22 to $59 \mathrm{mg} / \mathrm{L}$ (table 3). Dissolved organic carbon ranged from 1.2 to $5.8 \mathrm{mg} / \mathrm{L}$ (table 3 ).

Concentrations of nutrients generally were small (less than $1 \mathrm{mg} / \mathrm{L}$ ) (table 3 ). Nitrite plus nitrate concentrations were less than $0.05 \mathrm{mg} / \mathrm{L}$ as nitrogen in 14 samples. The largest nitrite plus nitrate concentration measured was $2.8 \mathrm{mg} / \mathrm{L}$ as nitrogen (table 3), which is less than the EPA maximum contaminant level (MCL) of $10 \mathrm{mg} / \mathrm{L}$ as nitrogen (U.S. Environmental Protection Agency, 1996). MCL's are health-based water-quality standards that are enforceable for all public water systems. There was no areal pattem in nitrite plus nitrate concentrations in shallow ground water (fig. 9). Nitrite concentrations were less than $0.01 \mathrm{mg} / \mathrm{L}$ as nitrogen in 21 of the 24 samples. Ammonia concentrations ranged from less than 0.01 to $0.27 \mathrm{mg} / \mathrm{L}$ as nitrogen, and ammonia plus organic nitrogen concentrations ranged from less than 0.2 to $0.5 \mathrm{mg} / \mathrm{L}$ as nitrogen (table 3 ). Phosphorous concentrations ranged from less than 0.01 to $0.4 \mathrm{mg} / \mathrm{L}$ as phosphorus. Dissolved oxygen concentrations generally were less than $1.0 \mathrm{mg} / \mathrm{L}$, and half the samples had dissolved oxygen concentrations less than 0.15 $\mathrm{mg} / \mathrm{L}$ (table 3).

Most trace elements analyzed had concentrations generally less than $20 \mu \mathrm{g} / \mathrm{L}$ (table 3 ), and no trace element concentrations exceed EPA MCL's. Concentrations of antimony, beryllium, lead, and silver were less than $1 \mu \mathrm{g} / \mathrm{L}$ in all samples (table 3 ). Barium, iron, manganese, molybdenum, and uranium were the only trace elements analyzed for that had median concentrations greater than $5 \mu \mathrm{g} / \mathrm{L}$ (table 3 ). Iron and manganese concentrations had a large range in shallow ground water, and manganese concentrations generally were larger than iron concentrations (table 3 ). Samples from seven wells exceeded the EPA SMCL of $300 \mu \mathrm{g} / \mathrm{L}$ for iron, and samples from 21 wells exceeded the EPA SMCL of $50 \mu \mathrm{g} / \mathrm{L}$ for manganese. Water containing concentrations of iron and manganese greater than the SMCL's can stain plumbing fixtures and have a metallic taste, but is not harmful to human health.

Samples were analyzed for radiological constituents including dissolved and suspended gross alpha activity, dissolved and suspended gross beta activity, and radon-222 (table 1). Dissolved gross alpha activity ranged from less than 0.6 to $120 \mu \mathrm{g} / \mathrm{L}$ as natural uranium, and dissolved gross beta activity ranged from 2.9 to 27 picocuries per liter $(\mathrm{pCi} / \mathrm{L})$ as strontium-90/yttrium-90 (Sr-90/Y-90) (table 3). All 


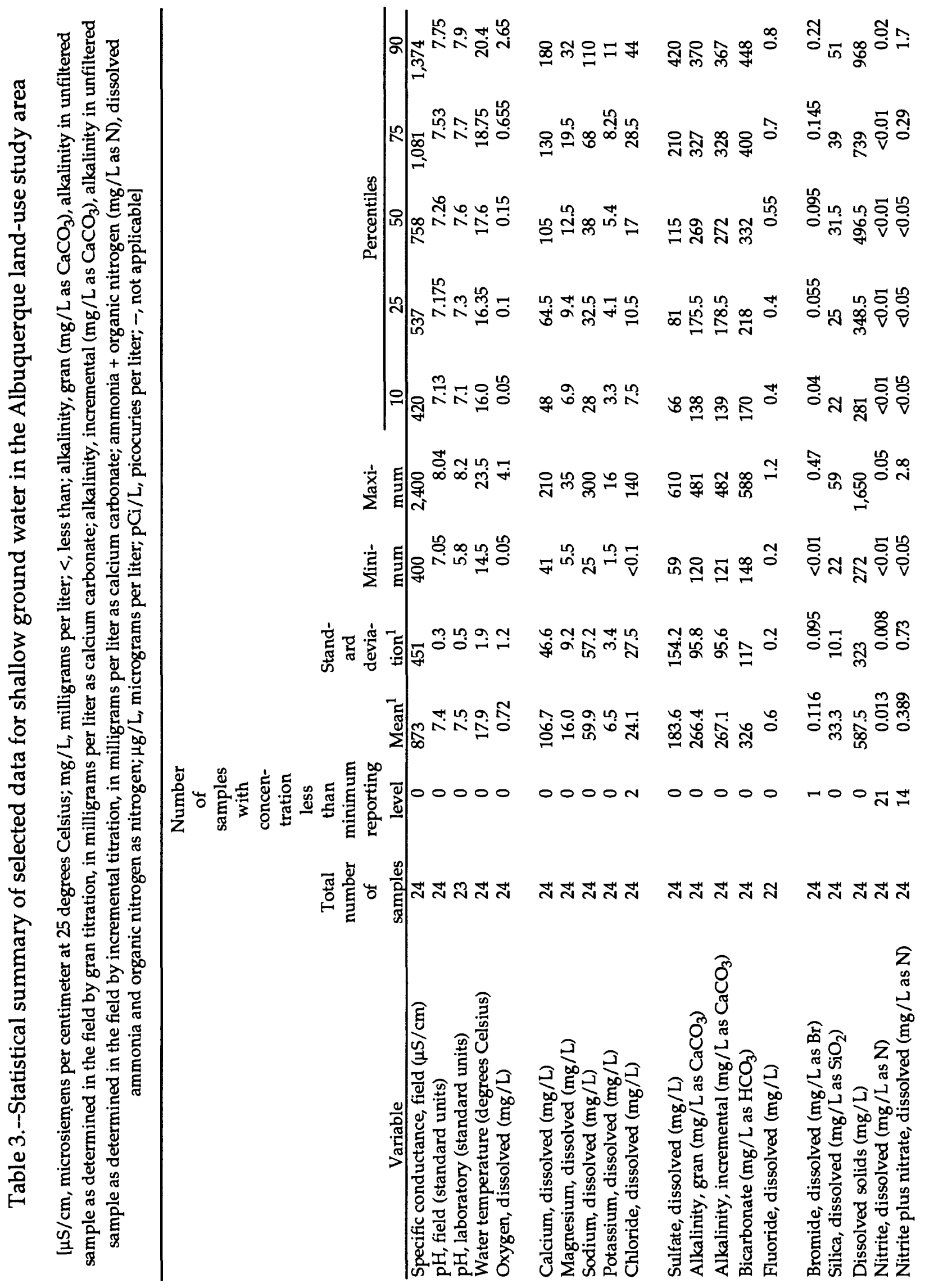




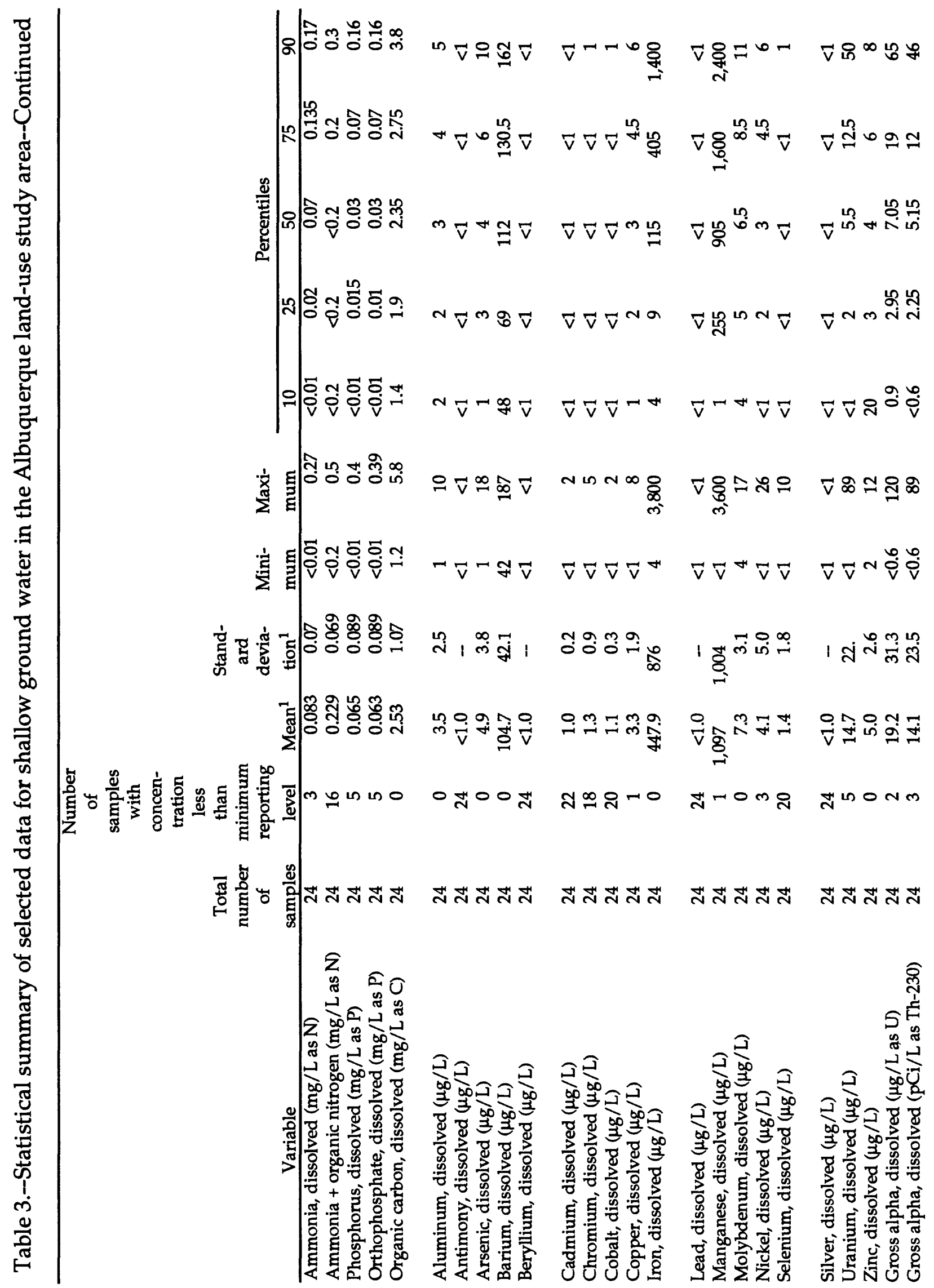




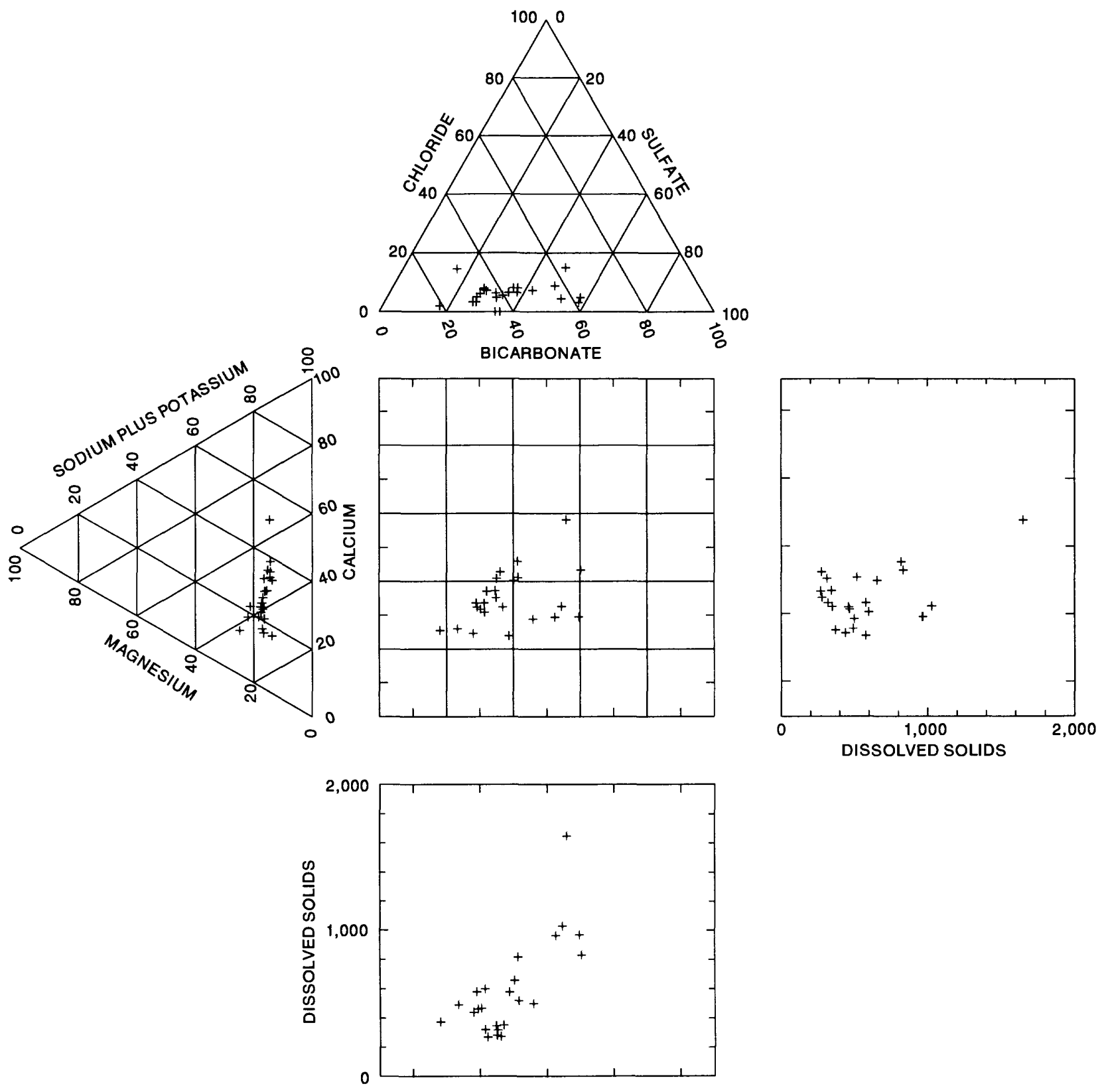

Figure 8.--Shallow ground-water compositions in the Albuquerque land-use study area. 


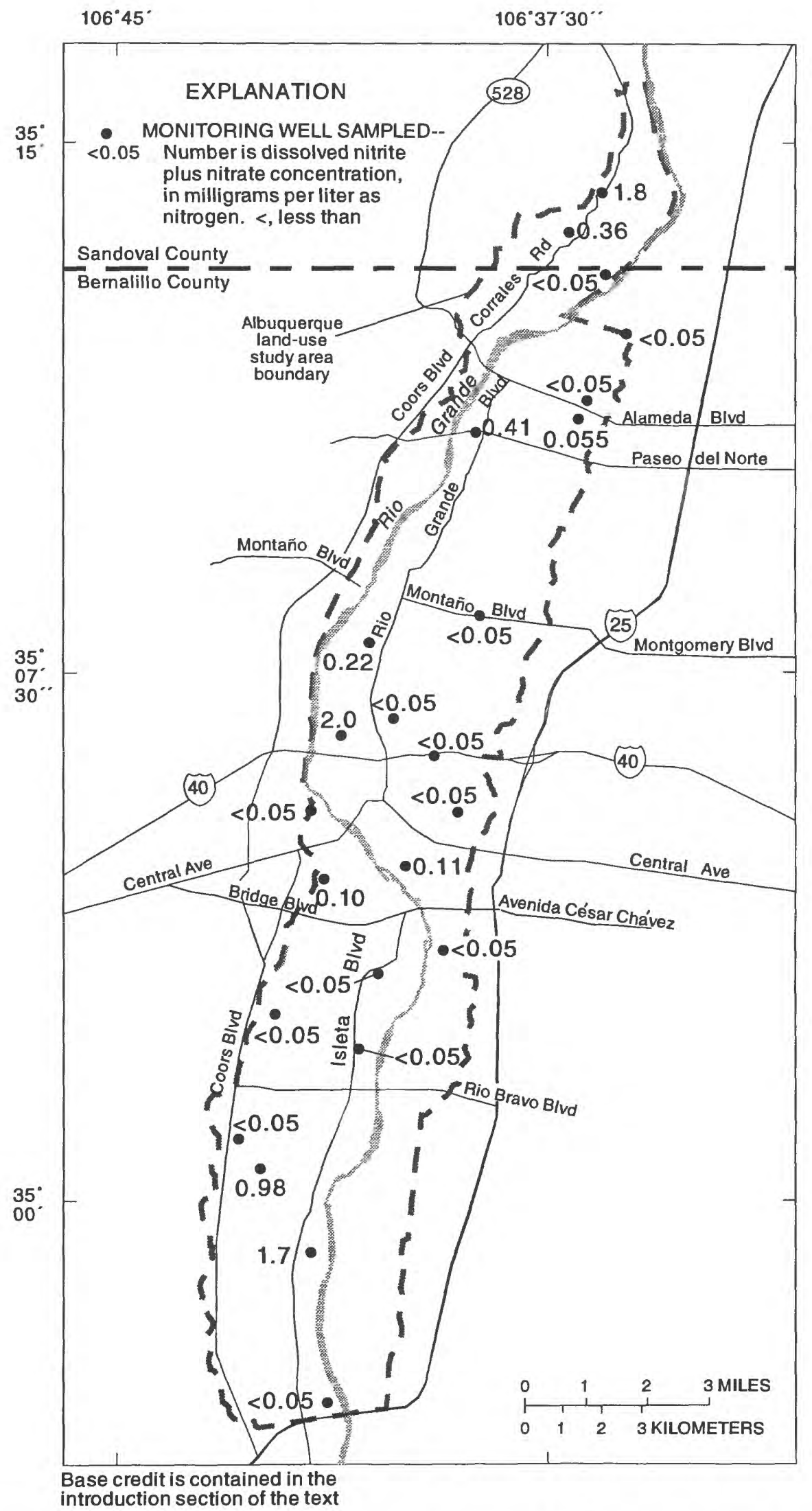

Figure 9.--Location and concentrations of dissolved nitrite plus nitrate as nitrogen in shallow ground water in the Albuquerque land-use study area. 
but one sample had a suspended gross alpha concentration less than $0.6 \mu \mathrm{g} / \mathrm{L}$ as uranium, and nine of the samples had suspended gross beta activities less than $0.6 \mathrm{pCi} / \mathrm{L}$ as Sr-90/Y-90 (table 3). Radon-222 concentrations ranged from 198 to $397 \mathrm{pCi} / \mathrm{L}$ (table 3 ).

The EPA has MCL's for both gross alpha and gross beta activity (U.S. Environmental Protection Agency, 1996); however, using the data collected during this study to compare the MCL's with measured gross alpha and beta activities in shallow ground water was not possible. Further sampling and analysis for specific radionuclides would be required to determine whether the MCL's were exceeded.

VOC's were detected in water from 5 of the 24 monitoring wells sampled (fig. 10). Cis-1, 2dichloroethene $(0.3$ and $0.3 \mu \mathrm{g} / \mathrm{L})$ and 1,1 dichloroethane $(0.2$ and $0.5 \mu \mathrm{g} / \mathrm{L})$, both of which are used as solvents, were the only compounds detected in more than one well. Methyltertbutylether, a gasoline additive $(7.9 \mu \mathrm{g} / \mathrm{L})$, and trichloroethylene, a metal degreaser $(1.1 \mu \mathrm{g} / \mathrm{L})$, had the largest concentrations of the detected VOC's. The other compound detected was p-iso-propyltoluene, a solvent $(0.4 \mu \mathrm{g} / \mathrm{L})$. The EPA has established MCL's of $70 \mu \mathrm{g} / \mathrm{L}$ for cis-1, 2 -

dichloroethene and $5 \mu \mathrm{g} / \mathrm{L}$ for trichloroethylene. These MCL's are much larger than concentrations measured in ground water in the ALS. No MCL's have been set for the other VOC's detected in the ALS. The EPA draft drinking-water lifetime health advisory for methylethertertbutyl is between 20 and $200 \mu \mathrm{g} / \mathrm{L}$ (U.S. Environmental Protection Agency, 1996). A health advisory is the maximum concentration in drinking water that is not expected to cause any adverse effects over a lifetime of exposure, with a margin of safety.

Pesticides were detected in water from 8 of the 24 monitoring wells sampled (fig. 11) although at concentrations much below EPA standards. Prometon, an herbicide, was the most frequently detected pesticide ( 5 of 24 wells). The largest concentration of prometon measured was $0.16 \mu \mathrm{g} / \mathrm{L}$. Bromacil $(0.52 \mu \mathrm{g} / \mathrm{L})$, carbofuran (estimated $0.010 \mu \mathrm{g} / \mathrm{L}$ ), carbaryl (estimated $0.021 \mu \mathrm{g} / \mathrm{L})$, and atrazine $(0.016$ $\mu \mathrm{g} / \mathrm{L}$ ) were the other pesticides detected in shallow ground water. Prometon, bromacil, and atrazine are herbicides used in non-cropland areas for weed control; atrazinie also is used in cropland areas for weed control. Carbofuran and carbaryl (Sevin) are insecticides used in agricultural and urban settings. The MCL for carbofuran is $40 \mu \mathrm{g} / \mathrm{L}$ and for atrazine is $3.0 \mu \mathrm{g} / \mathrm{L}$; both MCL's are much larger than the concentrations measured in shallow ground water. The EPA has not set MCL's for the other detected pesticides. The EPA final drinking-water lifetime health advisory is $100 \mu \mathrm{g} / \mathrm{L}$ for prometon, $90 \mu \mathrm{g} / \mathrm{L}$ for bromacil, and $700 \mu \mathrm{g} / \mathrm{L}$ for carbaryl (U.S. Environmental Protection Agency, 1996).

\section{SHALLOW GROUND-WATER QUALITY AND LAND USE}

The composition of water can be related to various physical, chemical, and biological processes that occur as water moves through the hydrologic cycle. In the ALS, the chemical composition of shallow ground water can, in some instances, be related to processes occurring as the result of past and present land-use practices.

The amount and composition of recharge to the shallow ground-water system, which probably vary for different land uses, are important factors that affect shallow ground-water composition in the ALS. A part of the surface water used for irrigation of agricultural lands infiltrates and recharges the shallow groundwater system. This recharge occurred in most of the ALS prior to conversion of land from agricultural to urban land use and presently occurs in the agricultural land-use areas. The composition of recharge water associated with agricultural land use would be similar to the composition of the surface water used for irrigation, although the water is affected by evaporation and transpiration and could leach or react with agricultural chemicals and minerals in the unsaturated zone. Recharge to the shallow ground-water system in residential land-use areas probably is limited to infiltration of septic-system effluent, leakage from municipal sewer pipes, and infiltration of water used on lawns and gardens. The composition of recharge water would be similar to the supply water to the residence, although the water could be affected by human wastes, chemicals used in the home and yard, and evaporation or transpiration. The amount of recharge to the shallow ground-water system in commercial/industrial areas probably is not substantial unless businesses in the area have septic systems. Improper disposal of chemical wastes or leaking storage tanks could be a source of contamination to shallow ground water in these areas. Recharge to the shallow ground-water system in the parks and golf courses land-use areas would be due to infiltration of ground water used to irrigate the areas. 


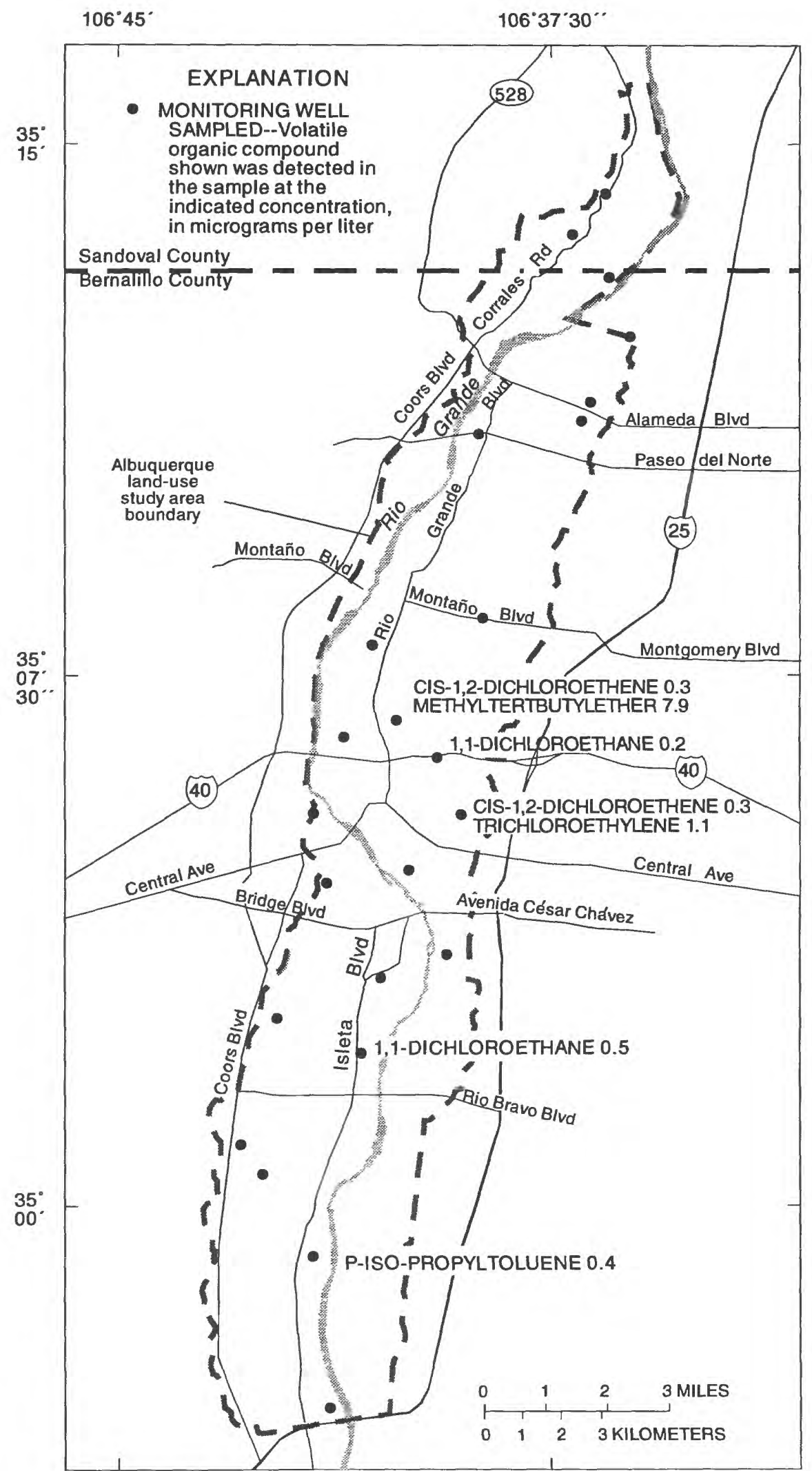

Base credit is contained in the introduction section of the text

Figure 10.--Location and concentrations of volatile organic compounds detected in shallow ground water in the Albuquerque land-use study area. 


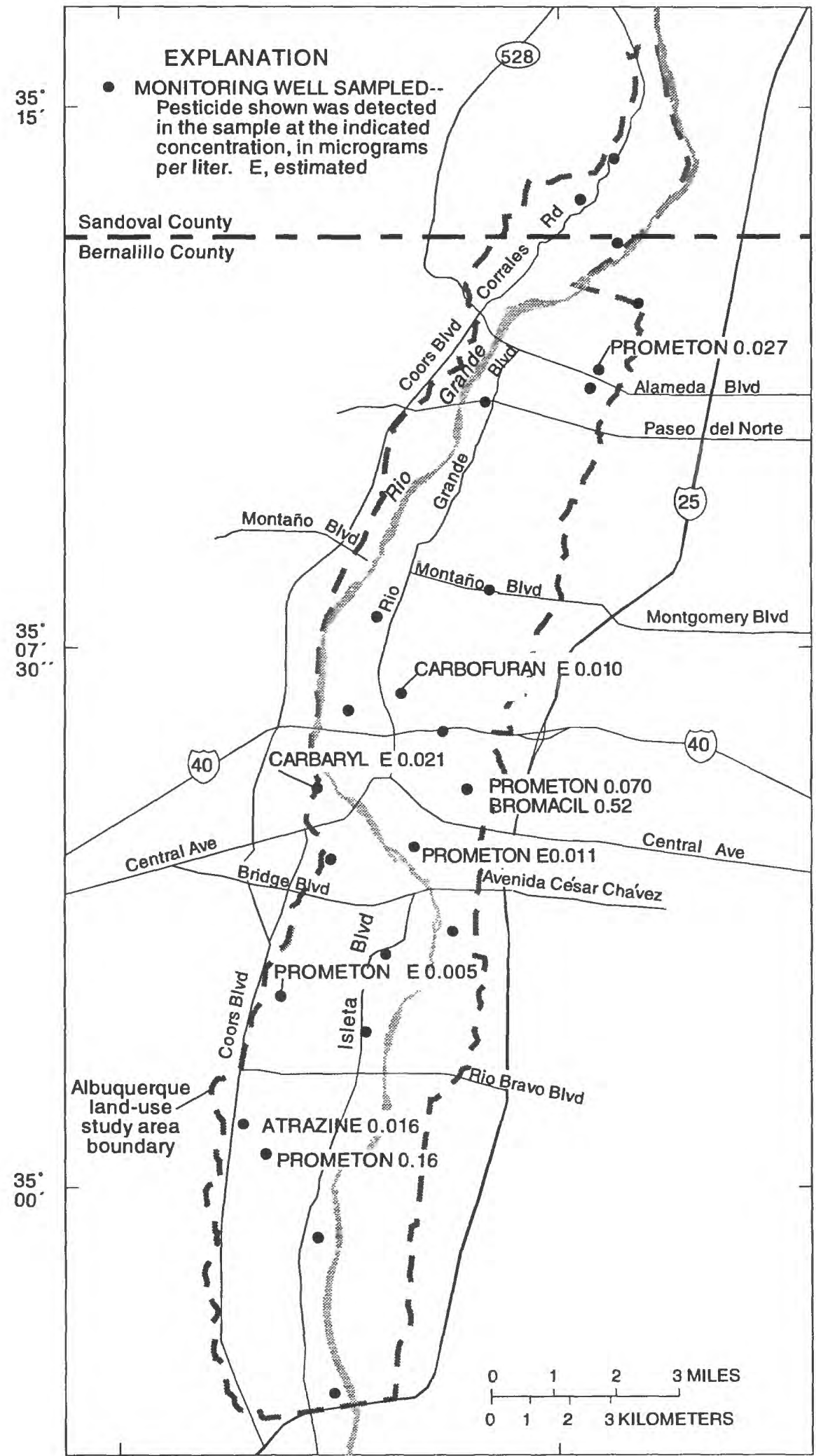

Base credit is contained in the introduction section of the text ground water in the Albuquerque land-use study area. 
The amount of recharge in the parks and golf courses land-use areas probably is less than that in agricultural land-use areas because water is applied uniformly by sprinklers in parks and golf courses, whereas the fields are flooded in agricultural areas. The composition of recharge water in parks and golf courses would be similar to irrigation water, although the water could be affected by leaching of agricultural chemicals or by reactions with minerals in the unsaturated zone and by evaporation or transpiration. Recharge in the urban vacant and vacant and bosque land-use areas would be limited to infiltration of precipitation, which also could occur in the other land-use areas.

Concentrations of chloride, sulfate, sodium, and calcium in shallow ground water in the ALS are related to past and present agricultural land use and to the system of canals and drains that result in substantial recharge of surface water to the shallow ground-water system and concentration of solutes by evaporation and transpiration in this water. Concentrations of sodium, chloride, nutrients, dissolved oxygen, dissolved organic carbon, iron, and manganese might be related to the use of septic systems (residential land use). There is no direct evidence that most trace element and radiochemical concentrations are related to land use. The presence of synthetic organic compounds in shallow ground water is indicative of land-use effects on shallow ground water. These compounds could get into shallow ground water by infiltration of irrigation water and the leaching of agricultural chemicals, infiltration of sewage effluent, infiltration of improperly disposed of industrial wastes, or leaking storage tanks. Determining the type of land use associated with the presence of a particular synthetic organic compound in shallow ground water was not possible because many of these compounds are used in a variety of land-use settings.

\section{Common Constituents}

Although there is a relatively large range in dissolved solids concentrations in shallow ground water in the ALS, the relative percentages of selected cations and anions do not vary substantially (fig. 8), indicating that the same physical and chemical processes could be controlling the chemical characteristics of shallow ground water. The chemical composition of water recharging shallow ground water in the ALS probably has a major effect on shallow ground-water quality. Infiltration of surface water is an important source of recharge to shallow ground water in the ALS. As discussed earlier, this includes infiltration of water from irrigation canals, surface drains, and water applied to the fields, which are associated with agricultural land use, and also infiltration of water from the Rio Grande.

Concentrations of selected solutes in surface water and shallow ground water were compared to determine whether infiltration of surface water, which is partly the result of past and present agricultural land use, is an important factor affecting shallow groundwater compositions and to determine whether other physical or chemical processes are affecting the composition of shallow ground water. Surface water in the imigation canals and applied to fields is diverted from the Rio Grande upstream from the ALS. Median concentrations of selected constituents in water from the Rio Grande at San Felipe (a site upstream from the ALS near the point where water is diverted into canals; fig. 1) from 1981 to 1990 were used to represent the composition of surface water (Rio Grande water) (table 4). Comparison of Rio Grande water and shallow ground water shows that much of the shallow ground water has a composition similar to that of Rio Grande water, although concentrations of chloride, sulfate, sodium, and calcium generally are larger in ground water than in surface water (fig. 12). The larger concentrations of these solutes in shallow ground water compared with surface water could be due to concentration of solutes in surface water by evaporation or transpiration prior to and during infiltration.

Concentrations of chloride, sulfate, sodium, and calcium were calculated for various amounts of evaporation of Rio Grande water to compare the composition of shallow ground water and Rio Grande water that has been affected by evaporation or transpiration prior to or during infiltration. Lines representing the calculated changes in solute concentrations (evaporation paths) in Rio Grande water are plotted in figure 12 . The mass of solutes were assumed to be conservative when calculating the evaporation paths. Data show the composition of shallow ground water to be similar to that of Rio Grande water that has been evaporated to varying degrees (fig. 12), although the compositions have some small differences. In general, most shallow groundwater samples plot slightly below the evaporation path of Rio Grande water, indicating that shallow ground 
Table 4.--Median concentrations of selected constituents in water from the Rio Grande at San Felipe, 1981-90, and average concentrations of selected constituents in precipitation and bulk deposition in the Albuquerque area

[mg/L, milligrams per liter; $\mu \mathrm{g} / \mathrm{L}$, micrograms per liter; --, no data; <, less than]

\begin{tabular}{|c|c|c|c|}
\hline Constituent & $\begin{array}{c}\text { Median concentration } \\
\text { in Rio Grande water } \\
\text { at San Felipe }\end{array}$ & $\begin{array}{l}\text { Average concentration } \\
\text { in precipitation (Popp } \\
\text { and others, 1984, p. 89) }\end{array}$ & $\begin{array}{c}\text { Average concentration } \\
\text { in bulk precipitation } \\
\text { (Popp and others, } \\
\text { 1984, p. 89) }\end{array}$ \\
\hline $\begin{array}{l}\text { Dissolved oxygen } \\
(\mathrm{mg} / \mathrm{L})\end{array}$ & 9.55 & - & - \\
\hline Calcium (mg/L as Ca) & 40 & 0.44 & 2.1 \\
\hline Sodium (mg/L as $\mathrm{Na})$ & 20 & 0.13 & 0.3 \\
\hline Chloride (mg/L as $\mathrm{Cl})$ & 5.9 & 0.2 & 2.7 \\
\hline Sulfate $\left(\mathrm{mg} / \mathrm{L}\right.$ as $\left.\mathrm{SO}_{4}\right)$ & 56 & 1.0 & 2.2 \\
\hline $\begin{array}{l}\text { Nitrite plus nitrate } \\
(\mathrm{mg} / \mathrm{L} \text { as } \mathrm{N})\end{array}$ & $<0.1$ & - & - \\
\hline $\begin{array}{r}\text { Total ammonia } \\
(\mathrm{mg} / \mathrm{L} \text { as } \mathrm{N})\end{array}$ & 0.06 & - & - \\
\hline $\begin{array}{l}\text { Total phosphorus } \\
\text { (mg/L as N) }\end{array}$ & 0.06 & - & - \\
\hline Arsenic ( $\mu \mathrm{g} / \mathrm{L}$ as As) & 2 & - & - \\
\hline Iron $(\mu \mathrm{g} / \mathrm{L}$ as $\mathrm{Fe})$ & 10 & - & - \\
\hline
\end{tabular}



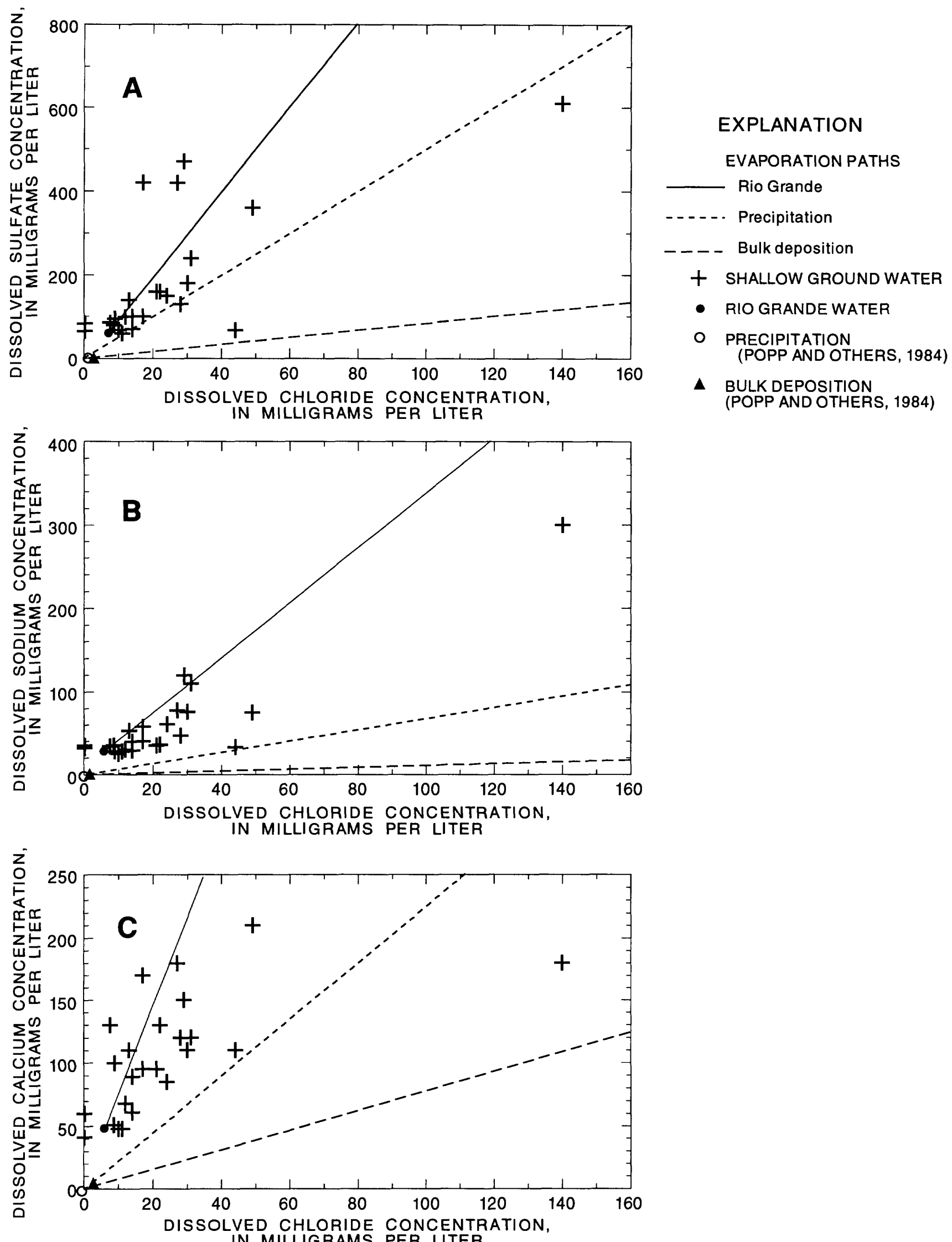

Figure 12.--Relations between concentrations of $(A)$ chloride and sulfate, $(B)$ chloride and sodium, and $(C)$ chloride and calcium in shallow ground water in the Albuquerque land-use study area. 
water has more chloride (excess chloride) relative to sulfate, sodium, and calcium than can be accounted for by infiltration and evaporation of Rio Grande water (fig. 12). Mixing of Rio Grande water with other sources of recharge such as precipitation or septicsystem effluent, which had different ratios of chloride to other ions than the Rio Grande water, could result in the excess chloride relative to other ions seen in shallow ground water.

Precipitation, which is a possible source of recharge in all land-use areas in the ALS, or precipitation that has been evaporated could be mixing with surface water to result in the observed composition of shallow ground water. Popp and others (1984) collected precipitation and bulk deposition samples in Albuquerque and presented the average concentrations of selected common constituents (table 4). These average concentrations were used to determine how evaporation paths of precipitation or bulk deposition compare to the composition of shallow ground water (fig. 12). Precipitation in this case represents samples of rain or snow only, whereas bulk deposition includes rain, snow, and atmospheric dust. Evaporation paths for precipitation and bulk deposition have a lower slope than those for Rio Grande water (fig. 12). This suggests that the amount of chloride relative to sulfate, sodium, and calcium is greater in precipitation and bulk deposition than in Rio Grande water. The shallow ground-water samples plot more closely to the evaporation paths for Rio Grande water than to the evaporation paths for precipitation or bulk deposition, meaning that infiltration of precipitation or bulk deposition probably is not the only source of recharge to shallow ground water (fig. 12). A mixture of small amounts of evaporated precipitation/bulk deposition and larger amounts of evaporated surface water could account for the observed composition of the shallow ground water.

Infiltration of septic-system effluent or leakage from municipal sewer pipes, which are important sources of recharge to the shallow ground-water system in residential land-use areas, could have an effect on shallow ground-water composition. Much of the area of the ALS is not sewered by a municipal system; thus, each residence has a septic system. Figure 13 shows the septic systems that were permitted by the Bemalillo County Environmental Health Department from about 1977 to 1988 . Many septic systems were installed prior to 1977 and after 1988 in the ALS. Population density is another indication of the relative density of septic systems in the ALS (fig. 13). The large number of septic systems in the ALS results in substantial recharge to the shallow aquifer. In unsewered areas that have a large population density, the effect of septic-system effluent on shallow groundwater composition could be substantial. Gallaher and others $(1987$, p. 43$)$ estimated that approximately 9,000 septic systems annually discharge about 511 million gallons of effluent to shallow ground water in the ALS south of Central Avenue. Leakage of sewage effluent from municipal sewer pipes, which would have a composition similar to septic-system effluent, is another source of recharge that could affect shallow ground-water quality. The composition of leakage from municipal sewer lines would be similar to septicsystem effluent. The solutes sodium, chloride, nitrogen (nitrate and ammonium), phosphorus, and organic carbon would be elevated in septic-system effluent compared to supply water (Cantor and Knox, 1986). The excess chloride in shallow ground water relative to evaporated Rio Grande water could be the result of the mixing of infiltrating surface water and infiltrating septic-system effluent.

Because several samples have compositions much different than those of most of the other samples, factors other than those already discussed might be affecting the chemical composition of these samples. Three samples have elevated sulfate concentrations (between 400 and $500 \mathrm{mg} / \mathrm{L}$ ) relative to the other shallow ground-water samples (fig. 12A). Ground water near these wells must be affected by recharge water containing relatively large amounts of sulfate compared to Rio Grande water. Two samples that contained chloride concentrations of 44 and $140 \mathrm{mg} / \mathrm{L}$ have much larger chloride concentrations relative to sulfate, sodium, and calcium than any other waters sampled (fig. 12). Water from these wells probably is affected by factors other than infiltration of surface water, precipitation, or septic-system effluent.

On the basis of the similarity in composition of surface water, surface water that has been affected by evaporation or transpiration, and shallow ground water, infiltration of surface water and the evaporation or transpiration of this water, which partly is the result of past and present agricultural land use, seem to be factors that affect the concentration of common constituents in shallow ground water in the ALS. The small excess chloride in shallow ground water relative to evaporated surface water could be due to mixing of shallow ground water with small amounts of 


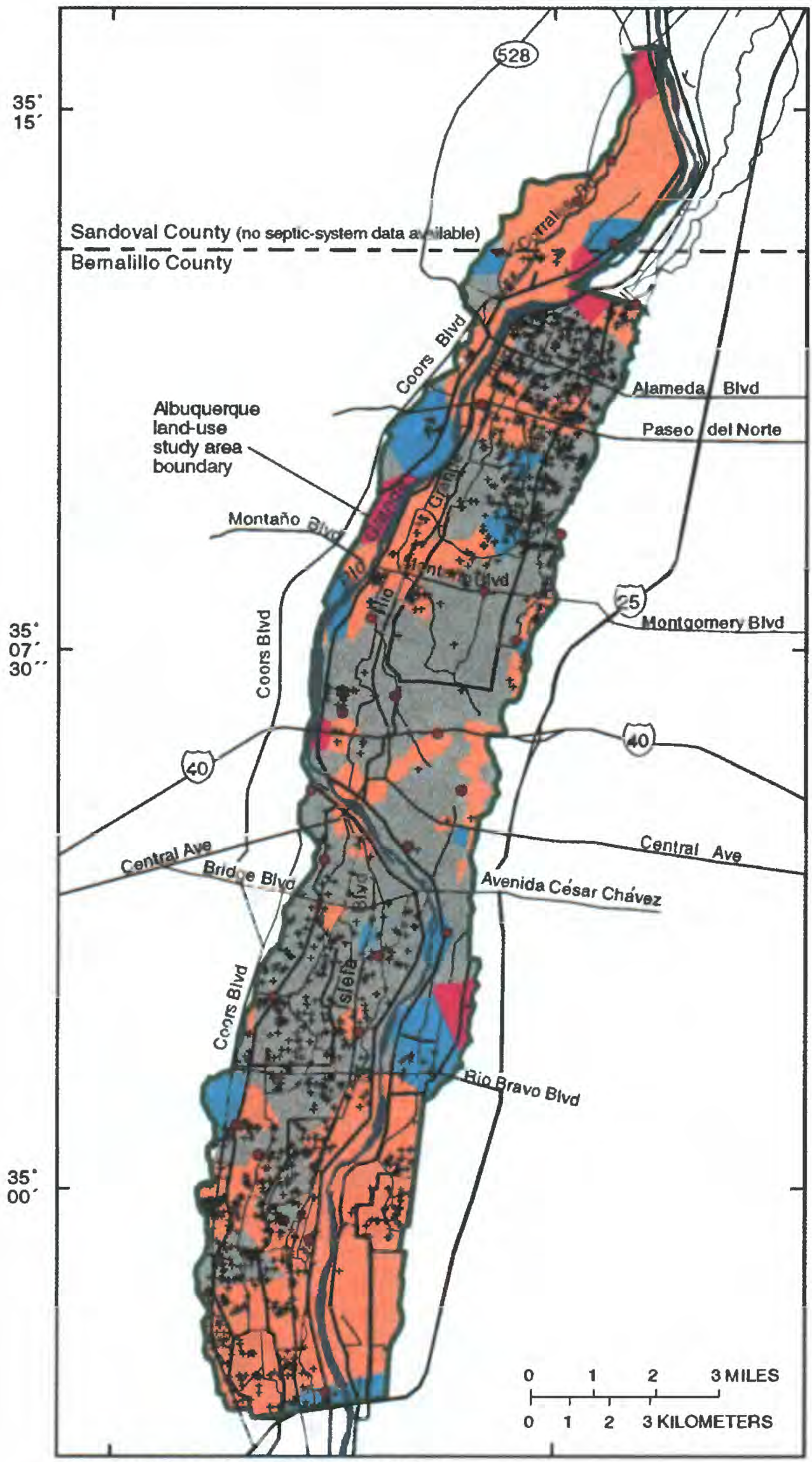

\section{EXPLANATION}

POPULATION DENSITY, IN PERSONS

PER SQUARE MILE

O TO 10

GREATER THAN 10 TO 100

GREATER THAN 100 TO 1,000

GREATER THAN 1,000

+ LOCATION OF SEPTIC SYSTEM

- MONITORING WELL SAMPLED

\section{Base credit is contained in the introduction} section of the text

Figure 13.--Population density and location of permitted septic systems installed prior to 1988 in the Albuquerque area (data from computer files of the County of Bernalillo, 1988; and U.S. Department of Commerce, 1990). 
precipitation/bulk deposition or septic-system effluent. Several samples have elevated sulfate or chloride concentrations relative to surface water affected by evaporation or transpiration, indicating that processes other than infiltration and evaporation of surface water are affecting the chemical composition of these samples.

\section{Nutrients, Dissolved Oxygen, and Dissolved Organic Carbon}

Small concentrations of phosphorus and nitrogen can occur naturally in ground water, but elevated phosphorous and nitrogen concentrations in ground water commonly are associated with human activities. Phosphorus and nitrogen are found in fertilizers, animal waste, and human waste. Leaching of fertilizers from agricultural land-use areas or infiltration of septic-system effluent in residential landuse areas can result in elevated phosphorous and nitrogen concentrations in shallow ground water. The phosphorous and nitrogen concentrations in Rio Grande water generally were less than $0.1 \mathrm{mg} / \mathrm{L}$ (table 4 ), thus infiltration of surface water probably is not a substantial source of phosphorus and nitrogen to ground water. Surface water used for irrigation could, however, leach fertilizers during infiltration, resulting in elevated concentrations of phosphorus and nitrogen in recharge water.

If phosphorus or nitrogen is transported to the ground-water system, its movement in a ground-water system is related to the forms or species of phosphorus or nitrogen present and solubility of the species. Many species of phosphorus are relatively insoluble in most ground water; therefore, phosphorus generally is found at small concentrations in ground water. Many nitrogen species are soluble in ground water and some are mobile in ground water. The stable or predominant species of nitrogen in a ground-water system can be affected by microbial processes and the oxidation/ reduction state of the ground-water system. Microbes can catalyze or mediate oxidation/reduction reactions that affect the predominant species of nitrogen present. The oxidation/reduction state of a ground-water system determines which nitrogen species are stable and which microbes are present.

The oxidation/reduction state of a ground-water system can be related to the amount of dissolved oxygen in the ground water. The ground-water system generally is considered oxidized or aerobic if dissolved oxygen is present. Nitrate is the stable nitrogen species in aerobic systems and is mobile in ground water. The ground-water system is considered reduced or anaerobic if dissolved oxygen concentrations are small. Nitrite or ammonium is the stable nitrogen species in anaerobic systems. Nitrite generally is converted to ammonium or nitrogen gas in anaerobic systems. Ammonium generally is soluble but not mobile in ground water because ammonium is adsorbed by clay particles.

Dissolved oxygen in shallow ground water is a function of the flux of infiltrating water and the amount of dissolved oxygen in this water, the amount of organic matter or carbon in the aquifer and in ground water, and the rate of oxidation of the organic matter. Dissolved oxygen is consumed by bacterially mediated decomposition of organic carbon (respiration). Organic carbon can occur naturally in the unsaturated zone or aquifer or can be dissolved in water. Respiration in a ground-water system results in decreases in the amount of dissolved oxygen in the ground water. If a large amount of organic carbon is in the aquifer or ground water, dissolved oxygen concentrations generally are small and the groundwater system is anaerobic because the dissolved oxygen is consumed during respiration.

Different sources of recharge water to the shallow ground-water system in the ALS would have different concentrations of dissolved oxygen or different oxidation/reduction states, and therefore different dominant nitrogen species. Surface water (median dissolved oxygen concentration $9.55 \mathrm{mg} / \mathrm{L}$; table 4) infiltrating and recharging the ground-water system as the result of agricultural land use would tend to be aerobic and nitrate would be the dominant nitrogen species. Septic-system effluent recharging the shallow ground-water system as the result of residential land use would tend to be anaerobic and contain dissolved organic carbon and ammonium. Septic-system effluent can contain dissolved organic carbon concentrations between 17 and $63 \mathrm{mg} / \mathrm{L}$ (Umari and others, 1993, p. 101). Oxidation of ammonium (nitrification) results in nitrate. However, this requires the presence of the correct bacteria and dissolved oxygen. Nitrate in anaerobic conditions and in the presence of dissolved organic carbon can be reduced to ammonium or to nitrogen gas (denitrification). For septic-system effluent to cause elevated nitrate concentrations in ground water, the ammonium in the septic-system effluent must be oxidized to nitrate. This 
requires dissolved oxygen that is also consumed during oxidation of the dissolved organic carbon in the effluent. If there is no sufficient flux of dissolved oxygen to shallow ground water that is being recharged with surface water and septic-system effluent, ground water will be anaerobic and ammonium will be the dominant nitrogen species. Elevated dissolved organic carbon concentrations also will exist in the ground water. If there is sufficient flux of dissolved oxygen, the dissolved organic carbon and ammonium in the effluent will be oxidized, and dissolved nitrate concentrations will be elevated.

The relatively small dissolved oxygen concentrations in shallow ground water in the ALS indicate that recharge water does not contain dissolved oxygen (no recharge associated with agricultural land use) or that dissolved oxygen in recharge water associated with past or present agricultural land use has been consumed as the result of respiration. The median dissolved oxygen concentration in shallow ground water in the ALS was $0.15 \mathrm{mg} / \mathrm{L}$ (table 3), indicating that dissolved oxygen concentrations in much of the shallow ground water are much smaller than those in surface water (table 4). The concentration of dissolved organic carbon in the ALS ranged from 1.2 to $5.8 \mathrm{mg} / \mathrm{L}$ and the median was $2.35 \mathrm{mg} / \mathrm{L}$ (table 3). Gallaher and others (1987, p. 199-206) found that natural background total organic carbon concentrations in ground water in the Albuquerque area generally are less than $0.5 \mathrm{mg} / \mathrm{L}$ and that those greater than $0.5 \mathrm{mg} / \mathrm{L}$ show the effects of septic-system effluent. Because Gallaher and others did not sample the shallow ground water (water at the water table) that was sampled during this study, their results might not be applicable to the shallow ground water. The large dissolved organic carbon concentrations in shallow ground water relative to those that Gallaher and others (1987) determined to be background levels might indicate that most shallow ground water in the ALS has been affected to some degree by septic-system effluent. On the basis of the excess chloride, relatively small dissolved oxygen concentrations, and large dissolved organic carbon concentrations in shallow ground water, infiltration of septic-system effluent (residential land use) has affected shallow ground-water composition in parts of the ALS.

There is probably considerable variation in the loading of dissolved oxygen (recharge associated with agricultural land use) and dissolved organic carbon (recharge associated with residential land use) to the shallow aquifer in the ALS. Six shallow ground-water samples had dissolved oxygen concentrations larger than $0.4 \mathrm{mg} / \mathrm{L}$ (fig. 14). Four of these samples had dissolved organic carbon concentrations less than 2 $\mathrm{mg} / \mathrm{L}$, which are relatively small compared with most samples, indicating that recharge water contains dissolved oxygen, not all of which is consumed by respiration in the area near these wells. Four samples had relatively small concentrations of dissolved oxygen (less than $0.2 \mathrm{mg} / \mathrm{L}$ ) and dissolved organic carbon (less than $2 \mathrm{mg} / \mathrm{L}$ ) (fig. 14). These relatively small dissolved oxygen and dissolved organic carbon concentrations could indicate relatively small loading of dissolved organic carbon as the result of infiltration of sewage effluent near these wells. The density of homes varied considerably near the wells sampled, which would affect loading of septic-system effluent to shallow ground water. The distance to irrigation ditches or proximity to large areas irrigated with surface water also varied from well to well, which affects the amount of surface water recharging shallow ground water. Some of the largest dissolved oxygen concentrations were found in water from wells near irrigation ditches or adjacent to the Rio Grande where relatively large amounts of surface water could be recharging.

The concentration of phosphorus in shallow ground water generally is less than $0.1 \mathrm{mg} / \mathrm{L}$ as phosphorus (appendix A). The small phosphorous concentrations probably are due to the small solubility of phosphorus in water and not related to land use.

The concentration of nitrite plus nitrate was less than $0.05 \mathrm{mg} / \mathrm{L}$ as nitrogen in more than half the samples collected; the largest nitrite plus nitrate concentration measured was $2.8 \mathrm{mg} / \mathrm{L}$ as nitrogen (table 3 ), indicating that the concentration of nitrate, which is the most mobile of the nitrogen species, is generally small in shallow ground water. Many samples have both dissolved oxygen concentrations less than $0.2 \mathrm{mg} / \mathrm{L}$ and dissolved nitrite plus nitrate concentrations less than $0.2 \mathrm{mg} / \mathrm{L}$ as nitrogen (fig. $15 \mathrm{~A}$ ), indicating that the ground water is anaerobic and that nitrate, if present in the ground water, has been converted to ammonia or nitrogen gas. Because ammonia concentrations generally are larger in samples containing small concentrations of nitrite plus nitrate (fig. 15B), nitrogen in the ground water near these wells probably is in the form of ammonia. Several samples had small concentrations of nitrite plus nitrate and ammonia, possibly indicating no flux 


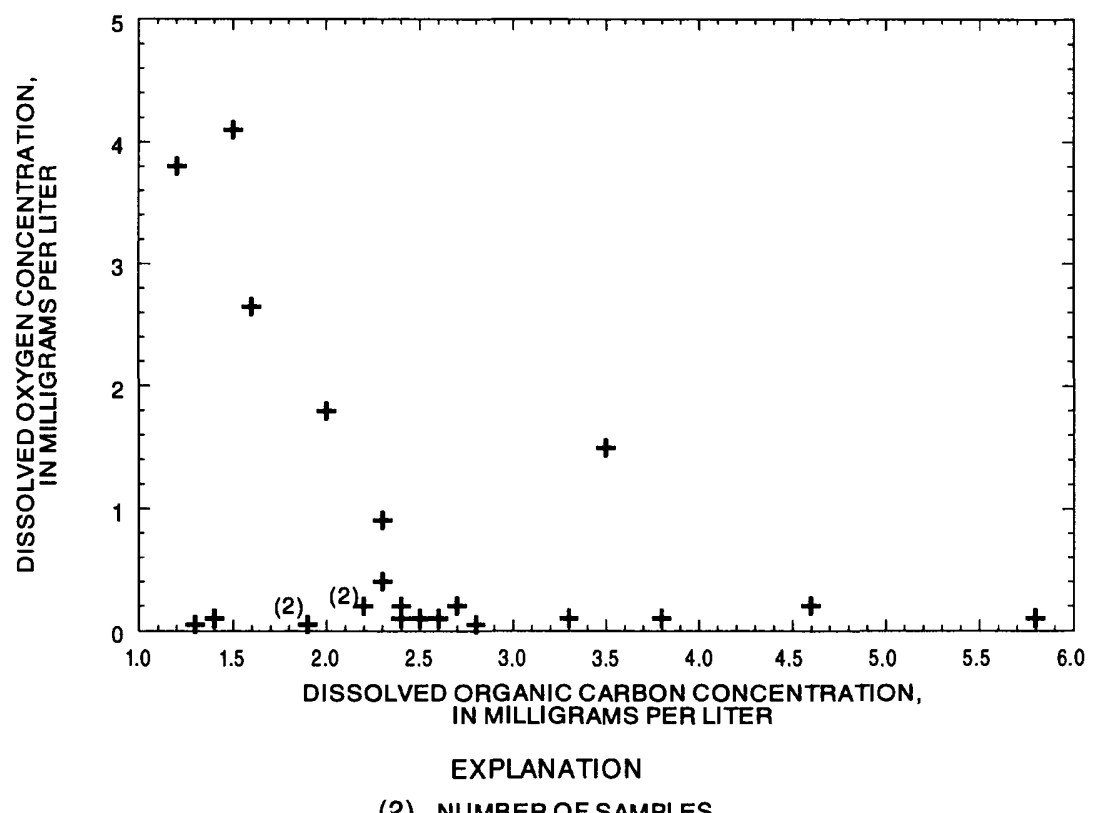

(2) NUMBER OF SAMPLES

Figure 14.--Relation between concentrations of dissolved organic carbon and dissolved oxygen in shallow ground water in the Albuquerque land-use study area.

of nitrogen to the ground water near these wells. Two samples had nitrite plus nitrate concentrations greater than $1.5 \mathrm{mg} / \mathrm{L}$ as nitrogen and dissolved oxygen concentrations less than $0.1 \mathrm{mg} / \mathrm{L}$ (fig. 15A). Because the dissolved organic carbon concentrations in these samples were some of the smallest measured in any of the samples (fig. 15C), dissolved organic carbon in the ground water may not be sufficient for the nitrate to be reduced to ammonium or for denitrification to occur. In general, samples containing the largest dissolved organic carbon concentrations had relatively small nitrite plus nitrate concentrations, and samples with the smaller dissolved organic carbon concentrations had the largest nitrite plus nitrate concentrations (fig. 15C).

Despite loading of nitrogen to the ground-water system by infiltration of septic-system effluent, the small nitrate concentrations in shallow ground water probably are due to the lack of dissolved oxygen and relatively large dissolved organic carbon concentrations in shallow ground water. The loading of dissolved organic carbon to the shallow aquifer that is associated with residential land use has resulted in small dissolved oxygen concentrations in much of the ALS. The small dissolved oxygen concentrations and larger dissolved organic carbon concentrations prevent the conversion of ammonia to nitrate in the effluent, and any nitrate in ground water would be converted to ammonia or nitrogen gas. Large ammonia concentrations are not found in shallow ground water because ammonia is adsorbed by clays in the aquifer or soil zone.

\section{Trace Elements}

Natural processes and human activities can alter concentrations of trace elements in shallow ground water. Natural processes include dissolution of naturally occurring minerals, adsorption, and complexation of trace elements. Human activities include infiltration of surface water used for irrigation, infiltration of septic-system effluent, and improper disposal of industrial waste. Human activities also can result in changes in the oxidation/reduction state of the groundwater system. This can affect concentrations of trace elements in shallow ground water because the solubility of many trace elements are related to oxidation/reduction conditions.

Concentrations of many trace elements were small or not measurable and therefore will not be discussed. Arsenic, barium, iron, manganese, molybdenum, and uranium were measurable in most samples and varied in concentration.

Comparison of concentrations of trace elements in surface water, septic-system effluent, and shallow ground water is not possible in most cases because of the lack of data. Existing data for Rio Grande water 


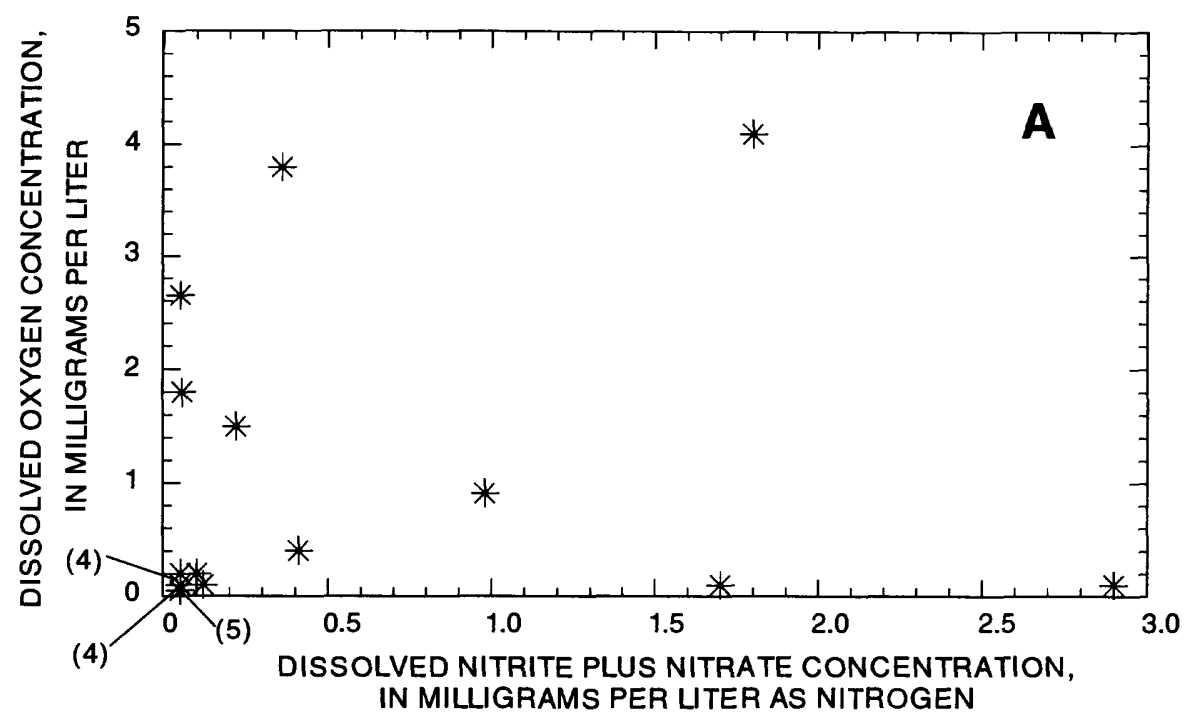

EXPLANATION

(4) NUMBER OF SAMPLES
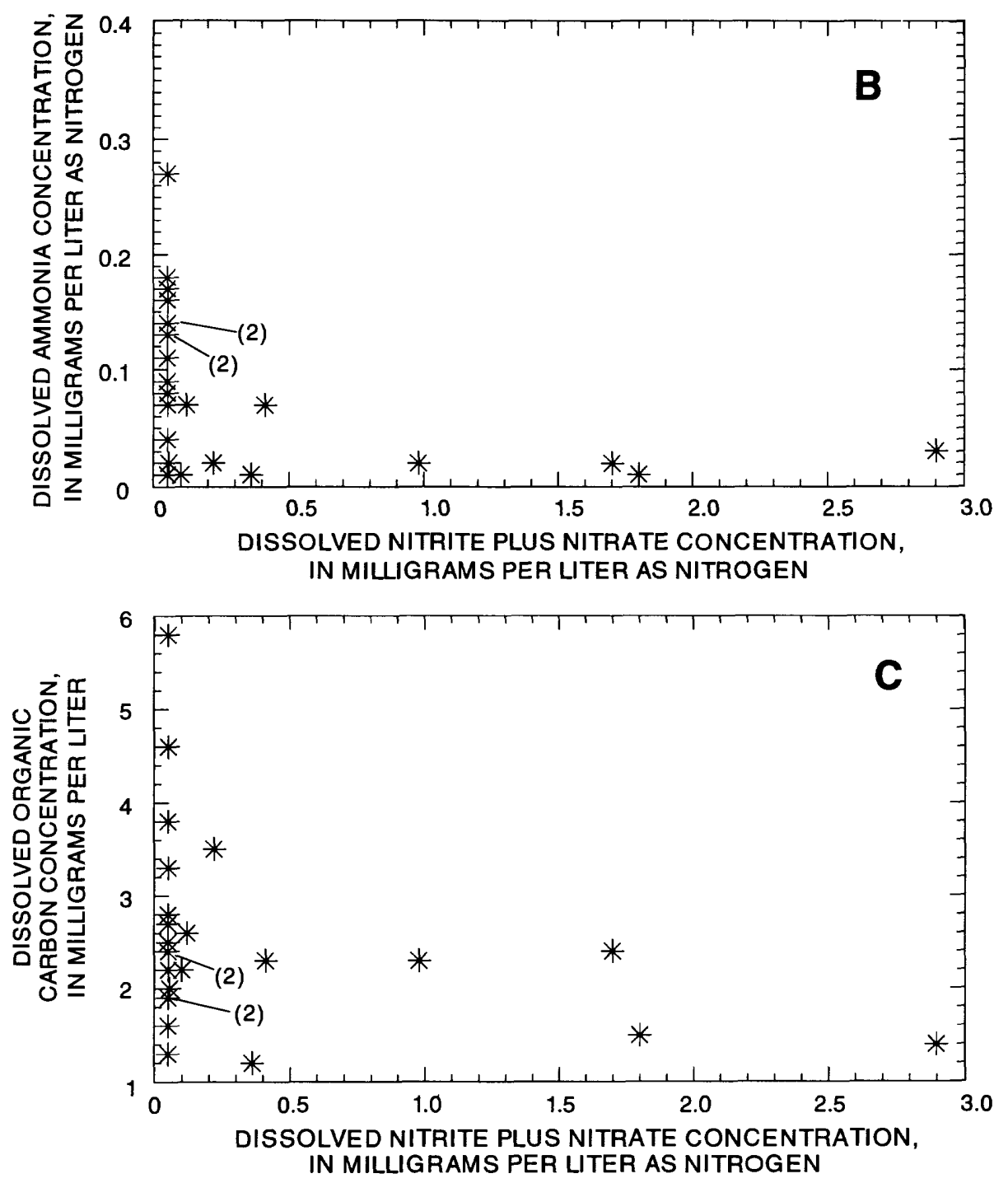

Figure 15.--Relations between concentrations of (A) dissolved nitrite plus nitrate and dissolved oxygen, (B) dissolved nitrite plus nitrate and dissolved ammonia, and (C) dissolved nitrite plus nitrate and dissolved organic carbon in shallow ground water in the Albuquerque land-use study area. 
indicate that arsenic and iron concentrations are relatively small (table 4). Trace element concentrations in septic-system effluent are dependent on trace element concentrations in supply water, which could vary considerably in the ALS, and generally would not be affected by human activities.

Dissolved arsenic concentrations ranged from 1 to $18 \mu \mathrm{g} / \mathrm{L}$ and the median was $4 \mu \mathrm{g} / \mathrm{L}$ (table 3 ). The median dissolved arsenic concentration in surface water was $2 \mu \mathrm{g} / \mathrm{L}$ (table 4), suggesting factors in addition to infiltration of surface water that are affecting arsenic concentrations in shallow ground water. All but one sample contained dissolved arsenic concentrations of $10 \mu \mathrm{g} / \mathrm{L}$ or less (appendix A). The largest dissolved arsenic concentration $(18 \mu \mathrm{g} / \mathrm{L})$ was in a sample that also had the largest dissolved organic carbon concentration (appendix A); arsenic concentrations, however, do not increase with dissolved organic carbon concentrations in most samples. Because dissolved arsenic concentrations are not related to dissolved oxygen concentrations, the oxidation/reduction state of the ground-water system probably has little effect on arsenic concentrations.

Dissolved barium concentrations ranged from 42 to $187 \mu \mathrm{g} / \mathrm{L}$ and the median was $112 \mu \mathrm{g} / \mathrm{L}$ (table 3). The concentration of dissolved barium can be controlled by the solubility of the mineral barite $\left(\mathrm{BaSO}_{4}\right)$ or by adsorption on iron and manganese oxides (Hem, 1985). Water containing larger sulfate concentrations generally has some of the smallest dissolved barium concentrations, indicating that barium concentrations can be controlled by the solubility of barite.

Dissolved iron concentrations ranged from 4 to $3,800 \mu \mathrm{g} / \mathrm{L}$ and the median was $115 \mu \mathrm{g} / \mathrm{L}$ (table 3). The median dissolved iron concentration in Rio Grande water was $10 \mu \mathrm{g} / \mathrm{L}$ (table 4), indicating that dissolved iron concentrations in most shallow ground water are affected by factors other than the infiltration of surface water. Iron is more soluble in reducing conditions (anaerobic) than in oxidizing conditions (Hem, 1985, p. 78-84). Because the largest dissolved iron concentrations were in samples containing small dissolved oxygen concentrations (fig. 16A), the oxidation/reduction state of the ground-water system might be affecting iron concentrations. Not all samples with small dissolved oxygen concentrations had large dissolved iron concentrations, so factors in addition to reducing conditions may affect dissolved iron concentrations. Samples with relatively small dissolved organic carbon concentrations (fig. 16B) and samples with small $\mathrm{pH}$ values (fig. 16C) contained some of the largest dissolved iron concentrations, suggesting that dissolved organic carbon and $\mathrm{pH}$ affect dissolved iron concentrations.

Dissolved manganese concentrations ranged from less than 1 to $3,600 \mu \mathrm{g} / \mathrm{L}$ and the median was 905 $\mu \mathrm{g} / \mathrm{L}$ (table 3 ). Because the largest dissolved manganese concentrations were in samples containing small dissolved oxygen concentrations (fig. 17A), the oxidation/reduction state of the ground-water system might be affecting dissolved manganese concentrations. Hem (1985, p. 84-89) said that in most natural waters any dissolved manganese will be in the reduced form and manganese generally is not soluble in aerobic conditions. The relation between dissolved manganese and dissolved organic carbon concentrations is not clear (fig. 17B). Gallaher and others $(1987$, p. 118$)$ reported that manganese concentrations in the Albuquerque area increase with total carbon concentrations. Manganese solubility in shallow ground water might be affected by $\mathrm{pH}$ because the largest manganese concentrations were in samples with smaller values of $\mathrm{pH}$ (fig. 17C).

Dissolved molybdenum concentrations ranged from 4 to $17 \mu \mathrm{g} / \mathrm{L}$ and the median was $6.5 \mu \mathrm{g} / \mathrm{L}$ (table 3). The largest dissolved molybdenum concentration was in the sample containing the largest dissolved organic carbon concentration (appendix A). Dissolved molybdenum concentrations generally increase with increasing dissolved organic carbon concentrations, suggesting that molybdenum concentrations might be related to loading of septic-system effluent or the oxidation/reduction state of the aquifer.

Dissolved uranium concentrations ranged from less than 1 to $89 \mu \mathrm{g} / \mathrm{L}$ and the median was $5.5 \mu \mathrm{g} / \mathrm{L}$ (table 3). Uranium generally is more soluble in oxidized conditions (Hem, 1985, p. 148). Two of the three largest dissolved uranium concentrations (sites 19 and 15) were measured in samples containing small dissolved oxygen concentrations, thus the oxidation/ reduction state of the ground-water system is not the only factor controlling dissolved uranium concentrations in shallow ground water in the ALS.

Because of the small concentrations and lack of variation of most trace elements, land use probably has not substantially affected the concentrations of most trace elements in shallow ground water. The relatively large dissolved iron and manganese concentrations in shallow ground water in the ALS might be the result of the small dissolved oxygen concentrations or the 


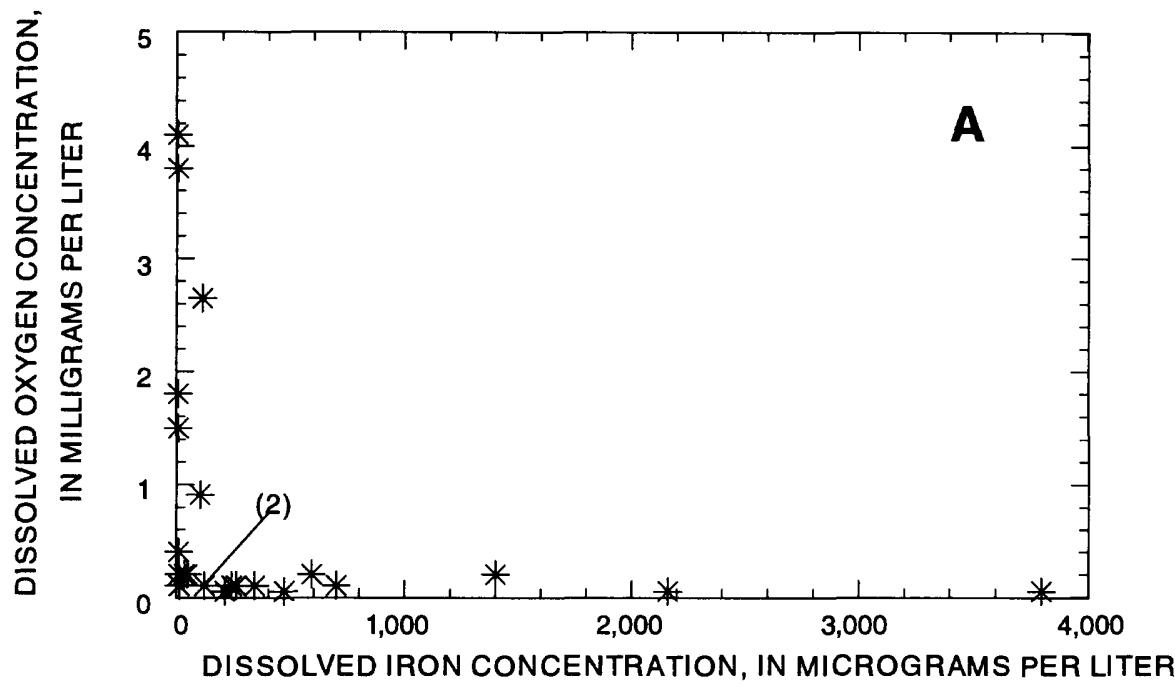

EXPLANATION

(2) NUMBER OF SAMPLES
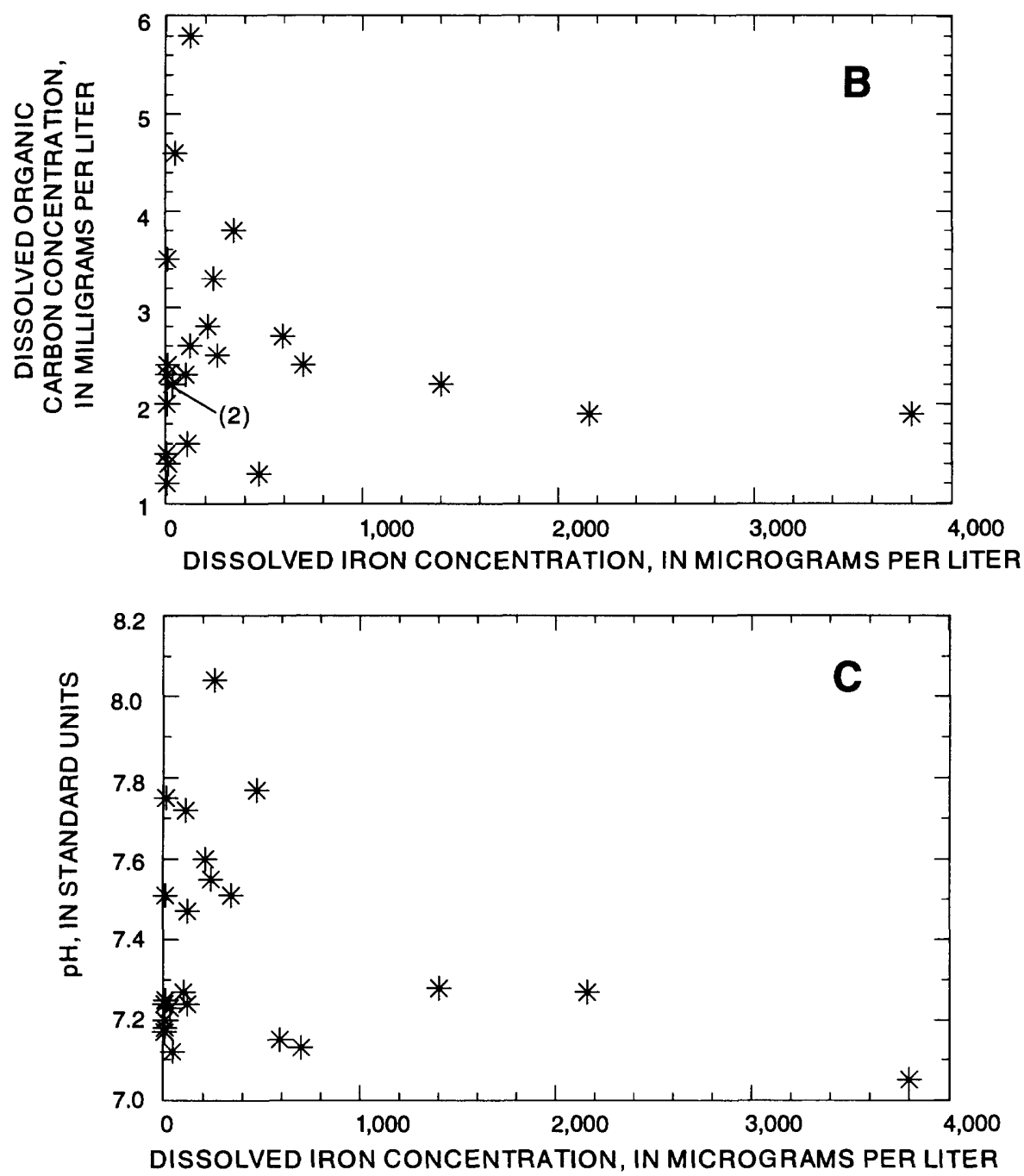

Figure 16.--Relations between (A) dissolved iron and dissolved oxygen concentrations,

(B) dissolved iron and dissolved organic carbon concentrations, and (C) dissolved iron concentration and $\mathrm{pH}$ in shallow ground water in the Albuquerque land-use study area. 

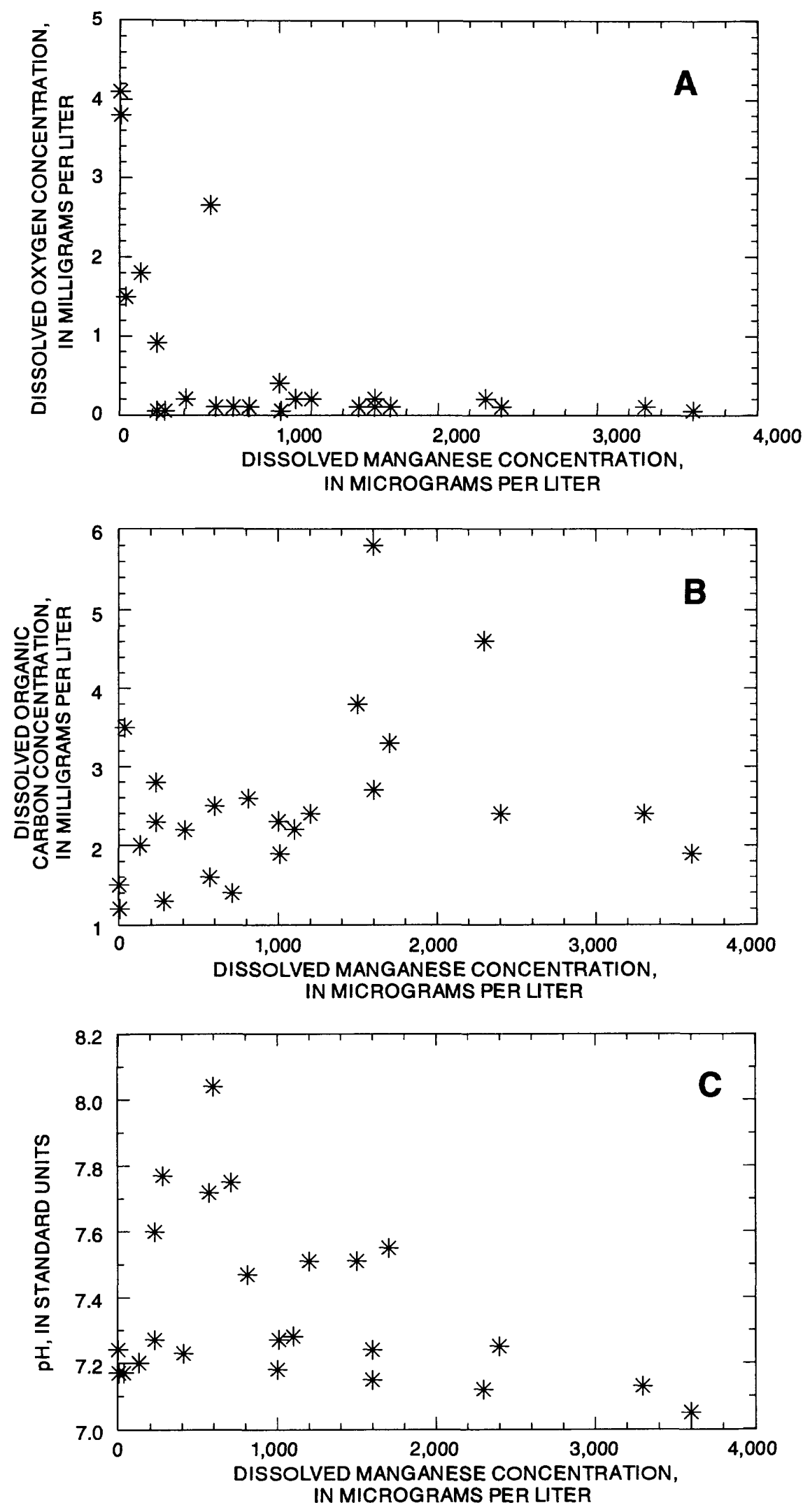

Figure 17.--Relations between (A) dissolved manganese and dissolved oxygen concentrations,

(B) dissolved manganese and dissolved organic carbon concentrations, and (C) dissolved manganese concentration and $\mathrm{pH}$ in shallow ground water in the 
reduced state of shallow ground water, which is due to residential land use. Naturally occurring iron and manganese minerals in the unsaturated zone or aquifer probably are dissolving because of the reduced state of the ground-water system. It is not clear what factors are most important in controlling the concentrations of other trace elements in shallow ground water. Hem (1985) stated that many trace elements are adsorbed to iron and manganese oxides. The dissolution of iron and manganese oxides in the aquifer might result in increases in concentrations of other trace elements as more of the iron and manganese minerals dissolve because the adsorbed trace elements also could go into solution.

\section{Radionuclides}

Radionuclides in water are from natural sources, such as the weathering of rocks and the interaction of cosmic rays with atmospheric particles, or from human activities, such as testing of nuclear weapons and industrial/medical uses. Agricultural land use also could affect the concentration of radionuclides in shallow ground water if radionuclides in irrigation water were concentrated by evaporation or transpiration and the water infiltrated to recharge the shallow ground-water system. Leaching or infiltration of radioactive wastes associated with industrial or commercial land use could result in elevated concentrations of radionuclides in shallow ground water. Determining the effects of land use on concentrations of radionuclides in shallow ground water is difficult because no data are available for gross alpha, gross beta, or radon-222 in surface water used for irrigation. Concentrations of radionuclides in supply water to residences are not known, so the effect of residential land use on radionuclide concentrations also is difficult to determine.

Gross alpha and gross beta activity measurements generally are used as screening tools because the measurements are not specific to a particular radionuclide. Gross alpha is a measure of all alpha radiation (positively charged helium nuclei) emitted from a sample. The main alpha-emitting substances in ground water are decay products of uranium and thorium, which generally occur naturally. Gross beta is a measure of all beta radiation (electrons or positrons) emitted from a sample. The main betaemitting substances in ground water are potassium -40 , which occurs naturally, and cesium-137 and strontium-
90, which are related to human activities. Gross alpha activities are reported in terms of the amount of natural uranium or equilibrium thorium-230 that would give the same count rates. Gross beta activities are reported in terms of the amount of equilibrium Sr-90/Y-90 or cesium-137 that would give the same count rates. In the tables, the activities are reported in terms of these different radionuclides.

The radioactive decay of radium-226, which is part of the radioactive decay series of uranium-238, results in radon-222. Radon-222 concentrations in ground water are the result of decay of radium-226 in the aquifer material (a function of the amount of uranium in aquifer materials) and, where reducing conditions exist, radium-226 in the ground water (Thomas and others, 1993). Radon-222 is a gas at the temperature and pressure found in ground water near the land surface.

Uranium generally is the most abundant alphaemitting radionuclide. Dissolved uranium concentrations were analyzed directly and ranged from less than 1 to $89 \mu \mathrm{g} / \mathrm{L}$ and the median concentration was $5.5 \mu \mathrm{g} / \mathrm{L}$ (table 3 ). Dissolved gross alpha activity was measured and reported as equivalent uranium (this method assumes that all alpha activity is due to radioactive decay of uranium). Dissolved gross alpha activities ranged from less than 0.6 to $120 \mu \mathrm{g} / \mathrm{L}$ as uranium and the median activity was $7.05 \mu \mathrm{g} / \mathrm{L}$ (table 3). A plot of dissolved uranium concentration and dissolved gross alpha activity as uranium indicates that a large amount of gross alpha activity measured in the samples is accounted for by the uranium concentration in the samples (fig. 18). Many samples have dissolved gross alpha activities as uranium slightly greater than what would be predicted from the uranium concentration (samples plot below the 1:1 line in fig. 18), indicating that a small amount of gross alpha activity is from alpha-emitting radionuclides other than uranium. The difference could also be accounted for by counting uncertainties (appendix A); however, counting uncertainties tend to result in gross alpha activities both larger and smaller than uranium concentrations.

Potassium-40, a natural isotope of potassium, is a major source of gross beta activity in ground water. The natural abundance of potassium- 40 is about 0.0117 percent of the potassium (Thomas and others, 1993). The potassium concentration in ground-water samples ranged from 1.5 to $16 \mathrm{mg} / \mathrm{L}$ and the median concentration was $5.4 \mathrm{mg} / \mathrm{L}$ (table 3 ). Dissolved gross 


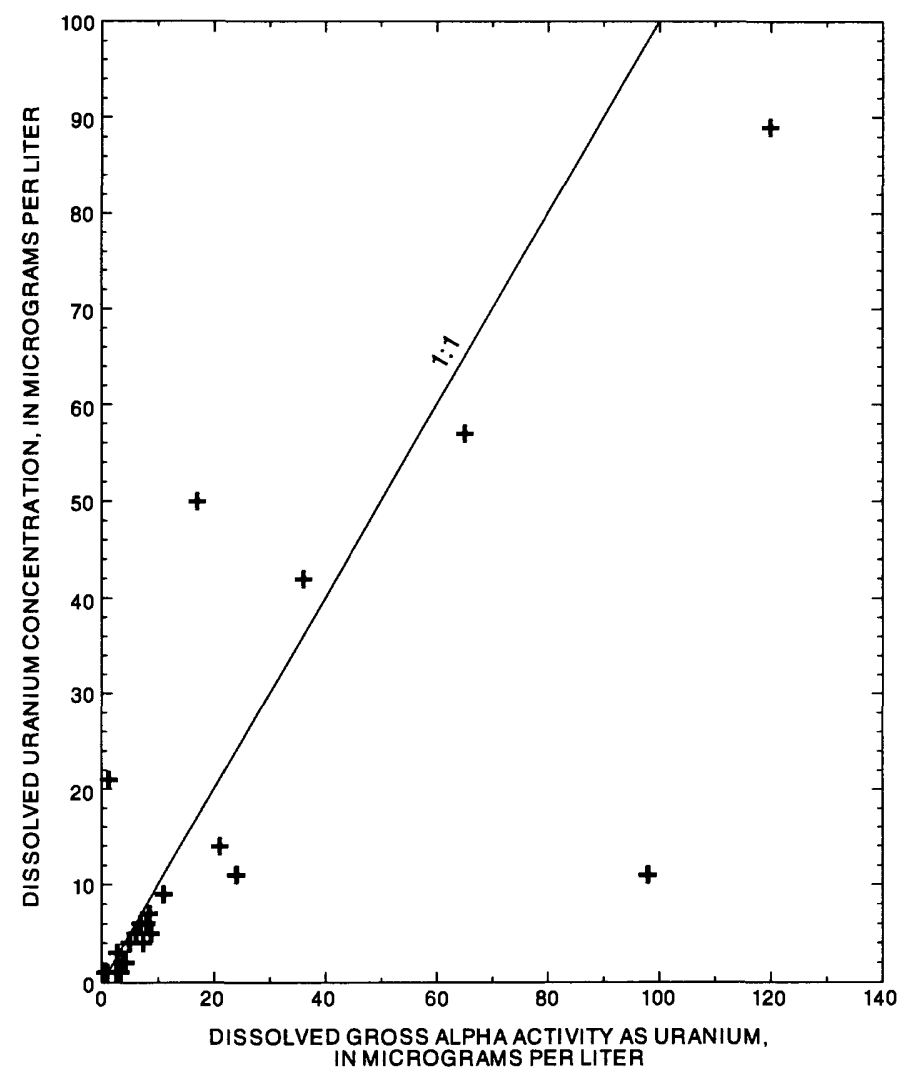

Figure 18.--Relation between dissolved gross alpha activity as uranium and dissolved uranium concentration in shallow ground water in the Albuquerque land-use study area.

beta activity reported as Sr-90/Y-90 ranged from 2.9 to $27 \mathrm{pCi} / \mathrm{L}$ and the median activity was $7.5 \mathrm{pCi} / \mathrm{L}$ (table 3). The gross beta activity from potassium-40 (in picocuries per liter) can be estimated by multiplying potassium concentrations (in milligrams per liter) by 0.818 , which assumes a natural abundance of potassium -40 to potassium of 0.0117 percent and a half life of potassium-40 of $1.28 \times 10^{9}$ years (Thomas and others, 1993, p. 463). A plot of dissolved gross beta activity as Sr-90/Y-90 and dissolved potassium indicates that a large part of the gross beta activity is the result of potassium-40 (fig. 19A). According to Thomas and others (1993), uranium-238 progeny grow in the samples between the time of collection and time of analysis and can result in significant beta activity that is distinct from the beta activity of water in the aquifer. The effect of the uranium-238 progeny can be estimated by subtracting out the beta activity due to potassium- 40 and plotting the adjusted value against uranium concentration in the sample (fig. 19B). Figure 19B shows that in several samples all beta activity is attributed to potassium-40 (adjusted values about 0 ) and that the adjusted beta activity generally increases with increasing uranium concentration. The increase in the adjusted beta activity with increasing uranium concentration may mean that the uranium-238 progeny are the source of the beta activity that cannot be attributed to potassium-40. Two samples have beta activity much larger than can be explained by the uranium and potassium concentrations (dissolved gross beta activity adjusted for beta activity due to potassium-40 greater than $14 \mathrm{pCi} / \mathrm{L}$ as $\mathrm{Sr}-90 / \mathrm{Y}-90$ ) (fig. 19B). One sample had a relatively large amount of suspended alpha activity $(7.9 \mu \mathrm{g} / \mathrm{L}$ as uranium) compared with the rest of the samples, which had suspended alpha activities less than $0.6 \mu \mathrm{g} / \mathrm{L}$. The decay of uranium in the suspended fraction of the sample could be the reason for the gross beta activity not due to potassium-40 in this sample. The reason for the excess gross beta activity in the other sample is unknown.

The amount of radon-222 in ground water is a function of the amount of uranium and radium-226 in the aquifer materials and dissolved in ground water. Radon-222 concentrations ranged from 198 to 397 $\mathrm{pCi} / \mathrm{L}$ and the median was $278.5 \mathrm{pCi} / \mathrm{L}$ (table 3 ). The larger radon-222 concentrations do not seem to be associated with samples that have large dissolved gross alpha activities (large dissolved uranium 

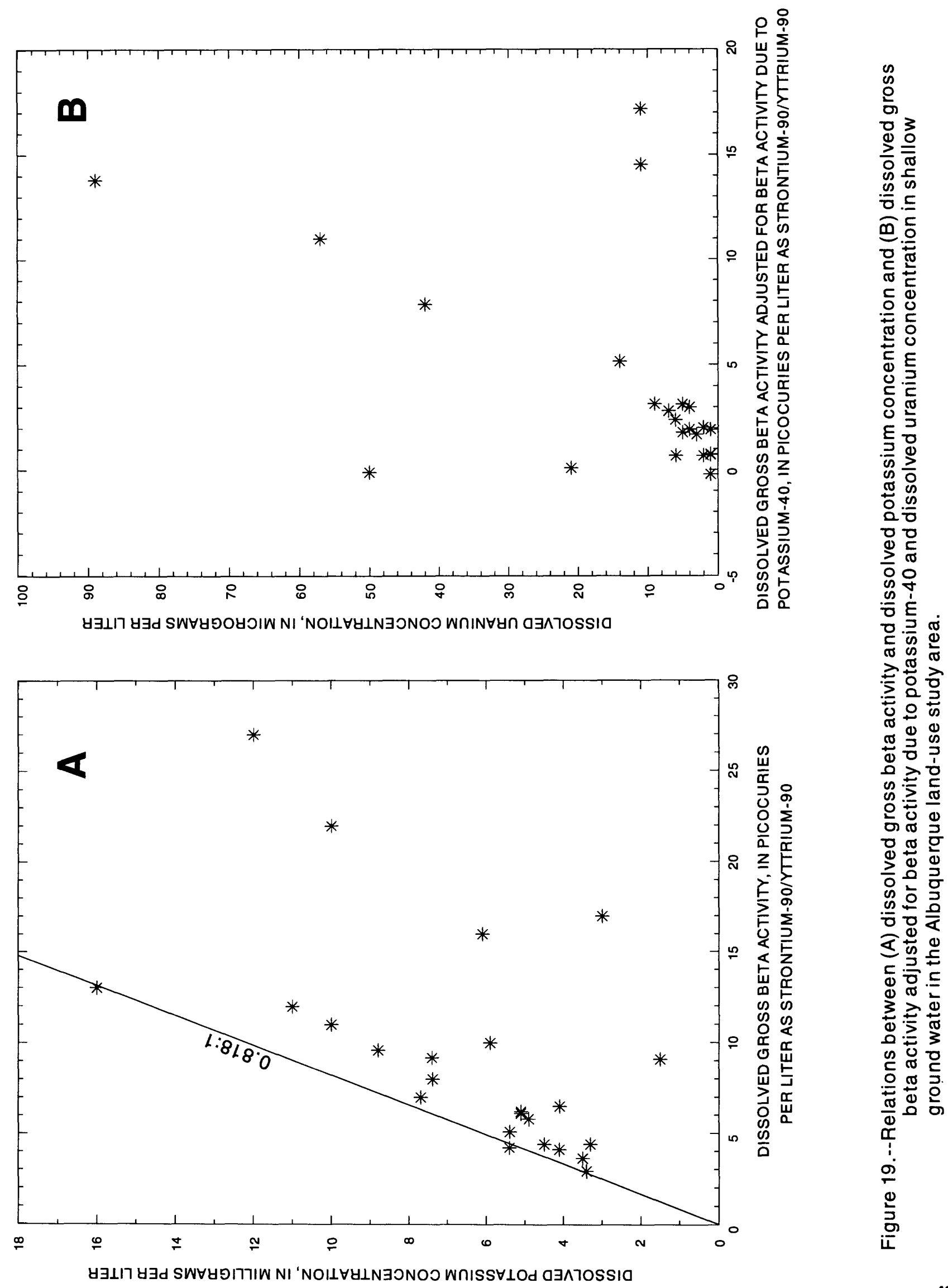
concentrations) (fig. 20). Larger radon-222

concentrations might indicate areas of larger uranium concentrations in the aquifer.

The gross alpha activity, gross beta activity, and radon-222 concentrations measured in shallow ground water seem to be the result of naturally occurring radionuclides. There is no direct evidence that land use has affected radionuclide concentrations or activities in shallow ground water in the ALS.

\section{Synthetic Organic Compounds}

The presence of synthetic organic compounds (VOC's and pesticides) in shallow ground water indicates that human activities have affected shallow ground-water quality. VOC's are organic compounds found in many petroleum products and are commonly used as metal degreasers, as solvents, and in cleaning compounds. Improper disposal of these compounds can result in the leaching or infiltration of these compounds to the shallow ground-water system.
Because of the varied and widespread use of VOC's, it is difficult to relate a particular land use with a specific compound. Pesticides also can be used in a variety of situations, making it difficult to relate a land-use activity with a specific pesticide. Although some pesticides are used only for agricultural purposes, most pesticides can be used in agricultural, residential, golf courses and parks, and commercial/industrial land-use areas.

One or more VOC's were detected in about 20 percent of the wells sampled in the ALS (seven detections in water from five wells) (fig. 10). The concentrations of individual VOC's detected were less than or equal to $0.5 \mu \mathrm{g} / \mathrm{L}$ in all but two samples. The compounds detected are used for metal degreasing, extraction solvents, and general solvents (Sax and Lewis, 1987).

One or more pesticides were detected in about 33 percent of the wells sampled in the ALS (nine detections in water from eight wells (fig. 11). Bromacil was detected at the largest concentration $(0.52 \mu \mathrm{g} / \mathrm{L})$. The concentrations of pesticides in all but two of the

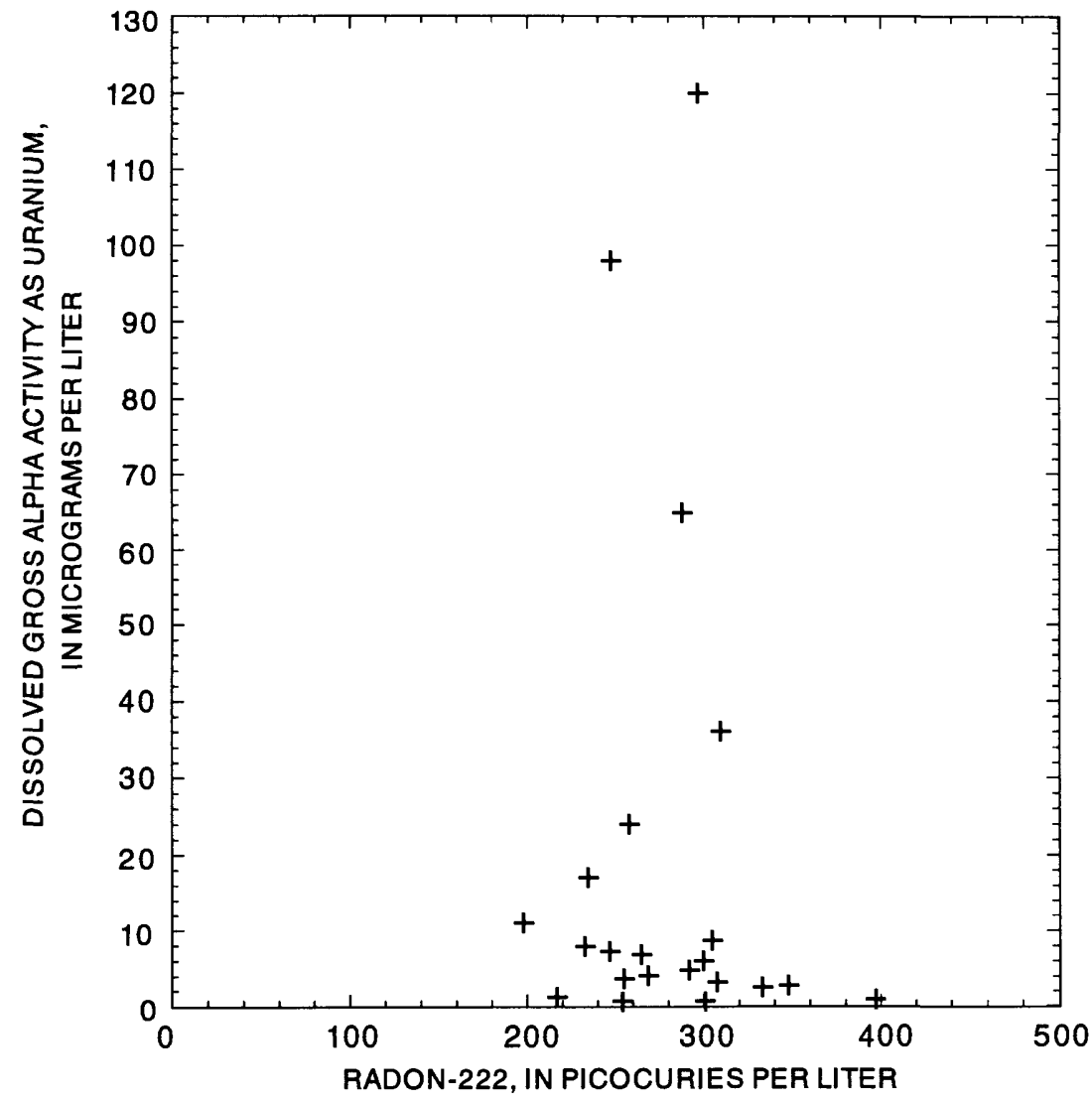

Figure 20.--Relation between radon-222 and dissolved gross alpha activity as uranium in shallow ground water in the Albuquerque land-use study area. 
samples were less than $0.1 \mu \mathrm{g} / \mathrm{L}$. Prometon was found in five of the eight wells where pesticides were detected. These five wells were not contiguous, indicating no point source of the prometon. Although prometon is relatively soluble in water, the concentrations measured were significantly less than the maximum amount that could be dissolved in water because the solubility of prometon is $620 \mathrm{mg} / \mathrm{L}$ (Meister, 1994).

There were differences in the number of wells in a particular land-use category and in the percentage of VOC and pesticide detections in samples from wells located in each of the different land-use categories (fig. 21). Land use at each well was determined using the LUTA data. The most common land-use category at the wells was vacant and bosque (10 wells) (fig. $21 \mathrm{~A})$. None of the wells were located in urban vacant land use. VOC's were detected most frequently in samples from wells in the parks and golf courses land-use category (fig. 21B), although VOC's were detected only in water from one of the two wells in this category. No pesticides were detected in samples from wells in agricultural land use. Pesticides were detected in 33 to 50 percent of the samples from wells in the other landuse categories (fig. 21C).

Because of the small number of wells in a particular land-use category, it is difficult to generalize about the relation between land use and the presence of VOC's or pesticides in shallow ground water. The largest percentage of detections for VOC's and pesticides ( 50 percent) was in water from wells in the parks and golf courses land-use category. No pesticides were detected in water from wells located in agricultural land use. The presence of VOC's in samples from wells in agricultural land use and lack of VOC's in samples from wells in commercial/industrial land use were unexpected because VOC's generally are more commonly used in commercial/industrial landuse settings than in agricultural land-use settings. These results could indicate that land use in the area adjacent to the well could affect water quality more than land use at the well.

The percentage of each land use relative to the total area within one-quarter mile of each well was determined to examine the relation between land use adjacent to the well and ground-water quality (table 5). The percentage of a particular land use around individual wells varied widely (table 5). The median percentages of the different land uses adjacent to all wells were determined to allow visual comparison of these median values to the actual percentages of different land uses adjacent to wells where VOC's or pesticides were detected (fig. 22). Larger percentages of a particular land use near wells where VOC's or pesticides were detected relative to the median percentage of the particular land use for all wells might indicate the land-use effects on water quality. For example, if the percentage of commercial/industrial land use adjacent to wells where VOC's were detected was larger than the median percentage of commercial/industrial land use adjacent to all the wells, it could indicate a relation between larger percentages of commercial/industrial land use adjacent to a well and VOC concentrations in ground water from the well. The largest median percentage ( 34 percent) of a land use within one-quarter mile of all wells sampled was in the residential land-use category (fig. 22). The median percentage of parks and golf courses was 0 percent of the area around all wells sampled. The percentage of commercial/industrial land use adjacent to three of the five wells where VOC's were detected was larger than the median percentage of commercial/industrial land use adjacent to all wells (fig. 22). The percentage of residential land use adjacent to five of the eight wells where pesticides were detected was larger than the median percentage of residential land use adjacent to all wells, whereas the percentage of agricultural land use adjacent to only two of the eight wells where pesticides were detected was larger than the median percentage of agricultural land use adjacent to all wells (fig. 22). A statistical test was used to determine if the above observations were statistically valid.

A Wilcoxon rank sum test indicated no significant difference at the 0.05 probability level in the median percentage of a particular land use near wells where VOC's were detected and wells where no VOC's were detected. Likewise there was no significant difference in the median percentages of land use near wells where pesticides were detected and near wells where pesticides were not detected. This indicates that, on the basis of the data collected in the ALS, a large percentage of a particular land use near a well does not result in a greater probability that VOC's or pesticides will be found in water from that well. 

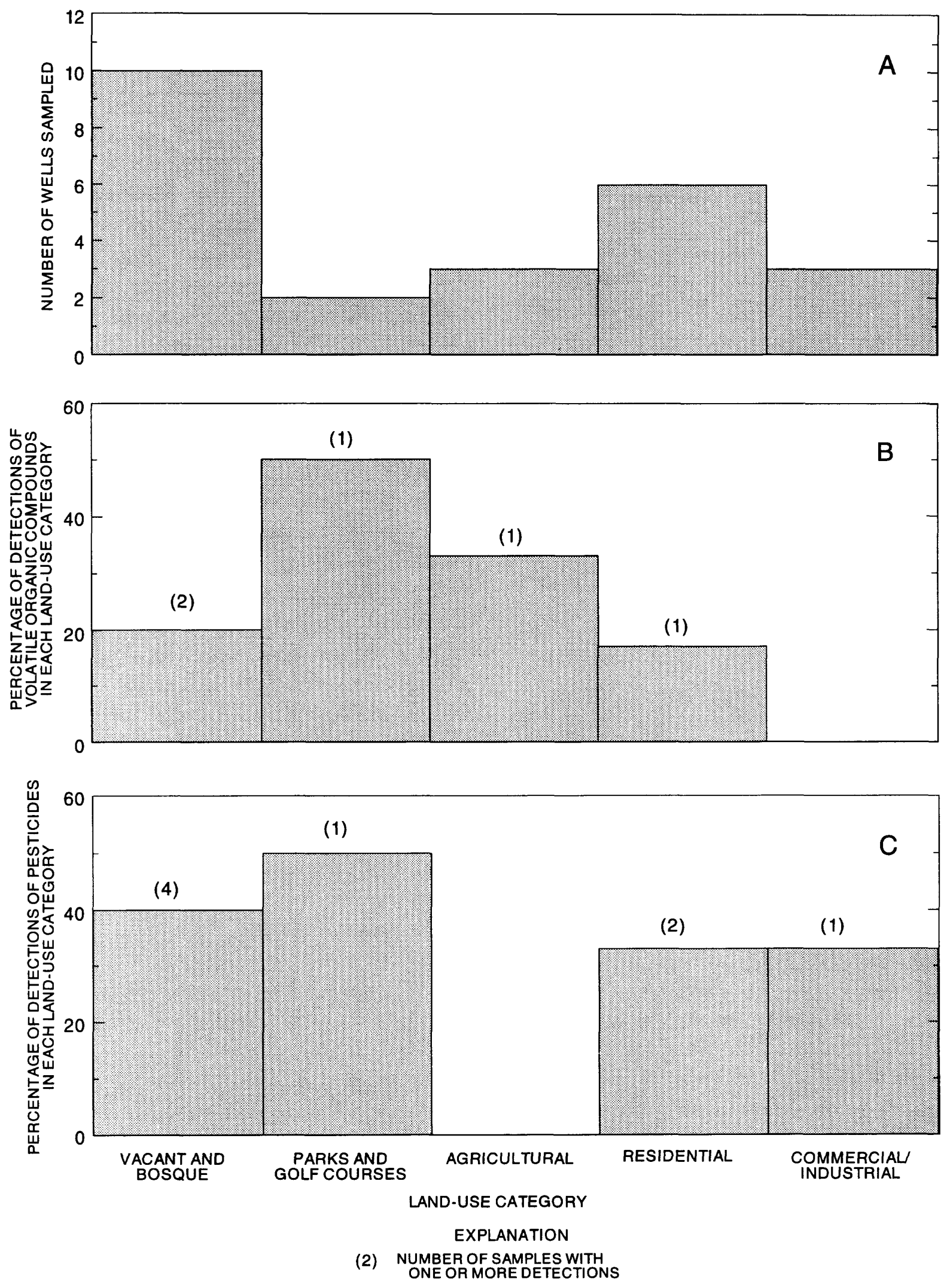

Figure 21.--Land use and (A) number of wells sampled, $(B)$ percentage of detections of volatile organic compounds in each land-use category, and (C) percentage of detections of pesticides in each land-use category (land-use data from Bell and others, 1993). 
Table 5.--Land use at the wells sampled and percentages of different land uses in 1/4-mile radius around wells sampled (land-use data from Bell and others, 1993)

[Percentages are rounded. Land use at well: $V$, vacant and bosque; $P$, parks and golf courses; A, agricultural; $R$, residential; $C$, commercial/industrial. $Y$, detected; $\mathrm{N}$, not detected]

\begin{tabular}{|c|c|c|c|c|c|c|c|c|c|}
\hline \multirow[b]{2}{*}{$\begin{array}{c}\text { Well } \\
\text { number } \\
\text { (fig. 2) }\end{array}$} & \multicolumn{6}{|c|}{$\begin{array}{l}\text { Percentage of land use } \\
\text { in } 1 / 4 \text {-mile radius of well }\end{array}$} & \multirow[b]{2}{*}{$\begin{array}{c}\text { Land } \\
\text { use at } \\
\text { well }\end{array}$} & \multirow{2}{*}{$\begin{array}{c}\text { Volatile } \\
\text { organic } \\
\text { com- } \\
\text { pounds } \\
\text { detected } \\
\text { at well }\end{array}$} & \multirow{2}{*}{$\begin{array}{l}\text { Pesti- } \\
\text { cides } \\
\text { detected } \\
\text { at well }\end{array}$} \\
\hline & $\begin{array}{c}\text { Vacant } \\
\text { and } \\
\text { bosque }\end{array}$ & $\begin{array}{l}\text { Parks } \\
\text { and golf } \\
\text { courses }\end{array}$ & $\begin{array}{l}\text { Urban } \\
\text { vacant }\end{array}$ & $\begin{array}{l}\text { Agricul- } \\
\text { tural }\end{array}$ & $\begin{array}{l}\text { Residen- } \\
\quad \text { tial }\end{array}$ & $\begin{array}{c}\text { mercial/ } \\
\text { indus- } \\
\text { trial }\end{array}$ & & & \\
\hline 1 & 44.4 & 0.0 & 0.0 & 37.1 & 18.4 & 0.0 & $\mathrm{~A}$ & $\mathbf{N}$ & $\mathrm{N}$ \\
\hline 2 & 30.8 & 0.0 & 0.0 & 36.3 & 32.9 & 0.0 & A & $Y$ & $\mathbf{N}$ \\
\hline 3 & 4.9 & 4.7 & 0.0 & 7.4 & 83.0 & 0.0 & $\mathbf{R}$ & $\mathbf{N}$ & $Y$ \\
\hline 4 & 20.3 & 0.0 & 2.2 & 29.2 & 40.6 & 7.8 & V & $\mathbf{N}$ & $Y$ \\
\hline 5 & 11.6 & 0.0 & 5.1 & 23.0 & 59.3 & 0.9 & V & $\mathbf{N}$ & $Y$ \\
\hline 6 & 2.0 & 5.3 & 0.2 & 42.6 & 46.3 & 3.6 & $P$ & $\mathbf{N}$ & $\mathbf{N}$ \\
\hline 7 & 51.9 & 0.0 & 2.2 & 0.7 & 45.2 & 0.0 & V & $\mathbf{N}$ & $Y$ \\
\hline 8 & 31.3 & 0.0 & 2.2 & 11.3 & 46.5 & 8.6 & V & $\mathbf{N}$ & $\mathbf{N}$ \\
\hline 9 & 2.1 & 3.8 & 1.5 & 22.3 & 59.8 & 10.4 & V & $\mathbf{N}$ & $\mathbf{N}$ \\
\hline 10 & 18.4 & 0.0 & 1.7 & 11.5 & 54.7 & 13.7 & $\mathbf{R}$ & $Y$ & $\mathbf{N}$ \\
\hline 12 & 41.3 & 3.4 & 6.6 & 0.0 & 13.6 & 35.1 & $C$ & $\mathbf{N}$ & $Y$ \\
\hline 13 & 30.0 & 30.3 & 1.3 & 0.0 & 25.8 & 12.7 & $\mathbf{P}$ & $Y$ & $Y$ \\
\hline 14 & 17.5 & 1.6 & 25.8 & 0.0 & 0.0 & 55.2 & V & $Y$ & $\mathbf{N}$ \\
\hline 15 & 11.4 & 0.0 & 0.0 & 1.7 & 84.8 & 2.2 & V & $Y$ & $Y$ \\
\hline 16 & 2.3 & 0.0 & 0.0 & 75.9 & 17.4 & 4.4 & $\mathbf{R}$ & $\mathbf{N}$ & $\mathbf{N}$ \\
\hline 17 & 42.5 & 0.0 & 0.0 & 21.7 & 35.8 & 0.0 & V & $\mathbf{N}$ & $\mathbf{N}$ \\
\hline 19 & 1.4 & 0.0 & 1.1 & 11.5 & 67.8 & 18.2 & $C$ & $\mathbf{N}$ & $\mathbf{N}$ \\
\hline 21 & 0.0 & 2.8 & 0.0 & 0.0 & 14.7 & 82.5 & $C$ & $\mathbf{N}$ & $\mathbf{N}$ \\
\hline 25 & 21.8 & 1.5 & 1.0 & 29.9 & 32.7 & 13.0 & V & $\mathbf{N}$ & $\mathbf{N}$ \\
\hline 26 & 19.3 & 3.8 & 2.1 & 16.3 & 33.1 & 25.4 & $\mathbf{R}$ & $\mathbf{N}$ & $Y$ \\
\hline 27 & 66.1 & 0.0 & 0.0 & 6.5 & 27.4 & 0.0 & V & $\mathbf{N}$ & $\mathbf{N}$ \\
\hline 28 & 46.9 & 0.0 & 5.6 & 21.6 & 25.9 & 0.0 & $\mathbf{R}$ & $\mathbf{N}$ & $\mathbf{N}$ \\
\hline 29 & 0.6 & 0.0 & 0.0 & 40.8 & 55.4 & 3.2 & A & $\mathbf{N}$ & $\mathbf{N}$ \\
\hline 30 & 13.6 & 0.0 & 0.0 & 51.1 & 31.3 & 4.0 & $\mathbf{R}$ & $\mathbf{N}$ & $\mathbf{N}$ \\
\hline
\end{tabular}



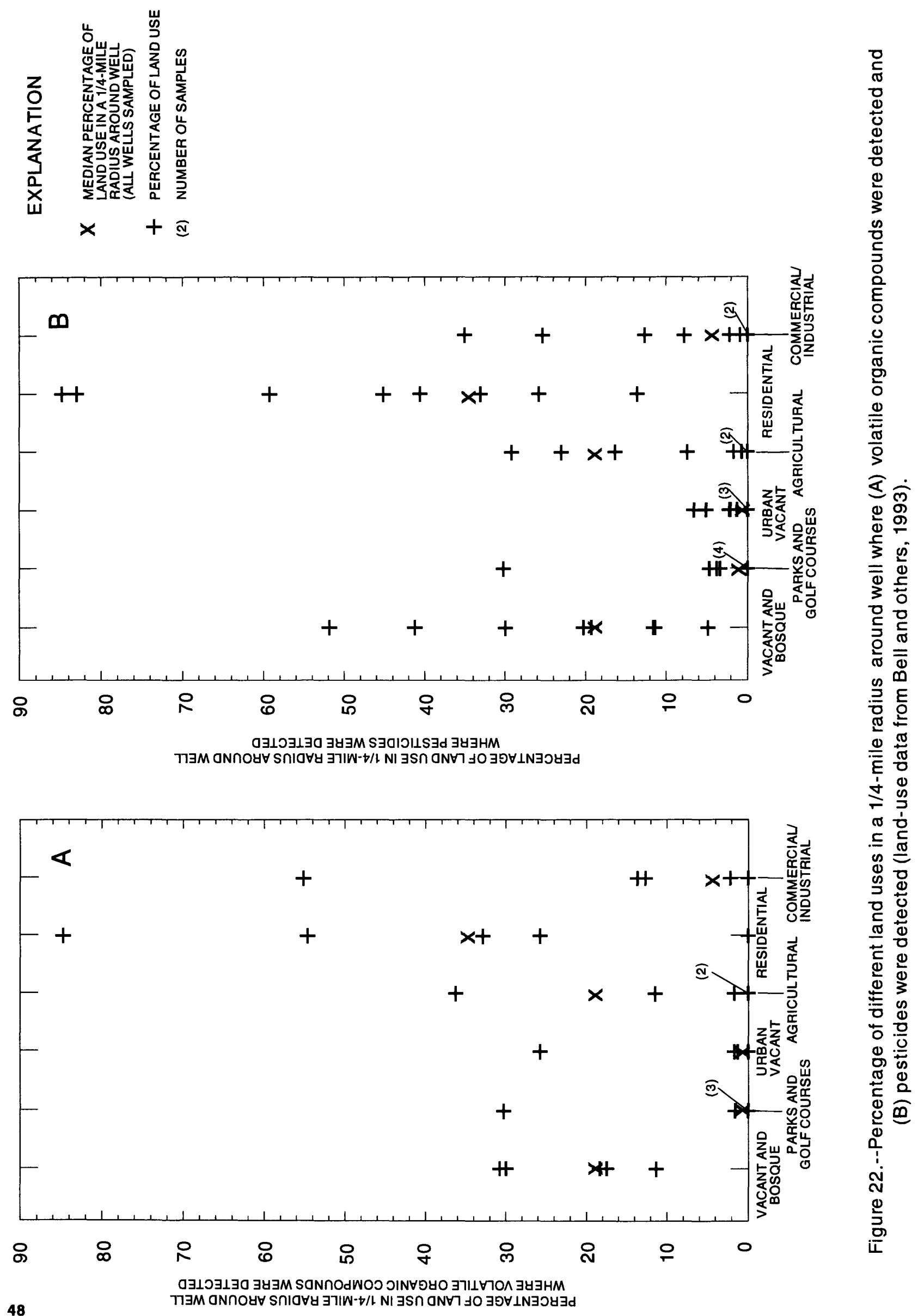
The presence of VOC's and pesticides in shallow ground water suggests human effects on shallow ground water in the ALS. Although few VOC's and pesticides were detected and their concentrations were relatively small, their presence in shallow ground water shows that shallow ground-water quality has been adversely affected. In areas where ground-water withdrawals have caused water levels to decline or where potentiometric gradients are downward, the VOC's and pesticides might move to deeper parts of the aquifer, which is used for public supply.

\section{SUMMARY}

This report describes the quality of shallow ground water and the relations between land use and the quality of that shallow ground water in an urban area in and adjacent to Albuquerque New Mexico. Water samples were collected from 24 shallow wells in the Rio Grande flood plain, where depth to water generally is less than 25 feet. Samples were analyzed for selected common constituents, nutrients, trace elements, radionuclides, volatile organic compounds, and pesticides.

The distribution of different land uses in the ALS is complex. Residential land use represents about 35 percent of the total study area, and agricultural land use represents about 28 percent of the area. In most of the ALS, agricultural land use is interspersed with residential land use, and generally neither is the dominant land use in an area. Vacant and bosque land use represents about 23 percent of the area and generally is limited to the area adjacent to the Rio Grande. Land use in the ALS historically has been changing from agricultural to urban.

The composition of shallow ground water in the ALS varies considerably. The dissolved solids concentration in shallow ground water in the ALS ranges from 272 to $1,650 \mathrm{mg} / \mathrm{L}$, although the relative percentages of selected cations and anions does not vary substantially. Calcium generally is the dominant cation and bicarbonate generaily is the dominant anion. Concentrations of nutrients generally were less than 1 $\mathrm{mg} / \mathrm{L}$. The concentrations of many trace elements in shallow ground water were below or slightly above 1 $\mu \mathrm{g} / \mathrm{L}$, and there was little variation in these concentrations. Barium, iron, manganese, molybdenum, and uranium were the only trace elements analyzed for that had median concentrations greater than $5 \mu \mathrm{g} / \mathrm{L}$. VOC's were detected in 5 of 24 samples. Cis-1,2-dichloroethene and 1,1dichloroethane were the most commonly detected VOC's (detected in two samples each). Pesticides were detected in 8 of 24 samples. Prometon was the most commonly detected pesticide (detected in 5 of 24 samples). The concentrations of VOC's and pesticides detected were much smaller than any EPA standards that have been established.

Infiltration of surface water and the evaporation or transpiration of this water, which partly is the result of past and present agricultural land use, seem to affect the concentrations of common constituents in shallow ground water in the ALS. The small excess chloride in shallow ground water relative to surface water that has been affected by evaporation or transpiration could be due to mixing of shallow ground water with small amounts of precipitation/bulk deposition or septicsystem effluent.

On the basis of small dissolved oxygen and large dissolved organic carbon concentrations and excess chloride, infiltration of septic-system effluent (residential land use) has affected the shallow groundwater composition in parts of the ALS. Because dissolved oxygen concentrations generally are small (less than $0.4 \mathrm{mg} / \mathrm{L}$ in all but six samples), any dissolved oxygen in recharge water associated with past or present agricultural land use probably has been consumed as the result of respiration. The relatively large dissolved organic carbon concentrations in shallow ground water might indicate infiltration of septic-system effluent. Small nitrogen concentrations in shallow ground water, despite the loading of nitrogen to the shallow ground-water system as the result of infiltration of septic-system effluent, probably are due to the small dissolved oxygen concentrations and relatively large dissolved organic carbon concentrations.

The small concentrations and lack of variation of most trace elements suggest that land use has not substantially affected the concentrations of most trace elements in shallow ground water. The relatively large dissolved iron and manganese concentrations in shallow ground water might be the result of the reduced state of shallow ground water due to residential land use. There is no direct evidence that land use has affected radionuclide concentrations or activities.

Because of the presence of synthetic organic compounds (VOC's and pesticides) in shallow ground water in the ALS, human activities probably have affected shallow ground-water quality. It was not 
possible to determine the type of land use associated with the presence of a particular synthetic organic compound in shallow ground water.

\section{REFERENCES}

Anderholm, S.K., 1987, Reconnaissance of hydrology, land use, ground-water chemistry, and effects of land use on ground-water chemistry in the Albuquerque-Belen Basin, Albuquerque, New Mexico: U.S. Geological Survey Water-Resources Investigations Report 86$4174,37 \mathrm{p}$.

1988, Ground-water geochemistry of the Albuquerque-Belen Basin, central New Mexico: U.S. Geological Survey Water-Resources Investigations Report 86-4094, 110 p.

Anderson, J.R., Hardy, E.E., Roach, J.T., and Witmer, R.E., 1976, A land use and land cover classification system for use with remote sensor data: U.S. Geological Survey Professional Paper 964, 28 p.

Bell, A.D., Oliver, K.J., and Blanney, K.R., 1993, Rio Grande land use inventory: Bureau of Reclamation technical memorandum, September 28, 1993.

Bjorklund, L.J., and Maxwell, B.W., 1961, Availability of ground water in the Albuquerque area, Bernalillo and Sandoval Counties, New Mexico: New Mexico State Engineer Technical Report 21, 117 p.

Canter, L.W., and Knox, R.C., 1986, Septic tank system effects on ground-water quality: Chelsea, Mich., Lewis Publishers, Inc., $336 \mathrm{p}$.

Faires, L.M., 1993, Methods of analysis by the U.S. Geological Survey National Water Quality Laboratory--Determination of metals in water by inductively coupled plasma-mass spectrometry: U.S. Geological Survey Open-File Report 92-634, 28 p.

Fishman, M.J., 1993, Methods of analysis by the U.S. Geological Survey National Water Quality Laboratory--Determination of inorganic and organic constituents in water and fluvial sediments: U.S. Geological Survey Open-File Report 93-125, 217 p.

Friedman, L.C., and Erdmann, D.E., 1982, Quality assurance practices for the chemical and biological analyses of water and fluvial sediments: U.S. Geological Survey Techniques of Water-Resources Investigations, book 5, chap. A6, $181 \mathrm{p}$.

Gabin, V.L., and Lesperance, L.E., 1977, New Mexico climatological data--Precipitation, temperature, evaporation, and wind--Monthly and annual means, 1850-1975: Socorro, N. Mex., W.K. Summers and Associates, $426 \mathrm{p}$.

Gallaher, B.M., McQuillan, B.M., Chavez, L.D., Hull, H.F., and Eidson, Millicent, 1987, Ground-water quality and public health, Albuquerque South Valley: New Mexico Health and Environment Department, $240 \mathrm{p}$.

Gilliom, R.J., Alley, W.M., and Gurtz, M.E., 1995, Design of the National Water-Quality Assessment Program-Occurrence and distribution of water-quality conditions: U.S. Geological Survey Circular 1112, $33 \mathbf{p}$.

Hawley, J.W., and Haase, C.S., 1992, Hydrogeologic framework of the northern Albuquerque Basin: Socorro, New Mexico Bureau of Mines and Mineral Resources Open-File Report 387, variously paged.

Hem, J.D., 1985, Study and interpretation of the chemical characteristics of natural water: U.S. Geological Survey Water-Supply Paper 2254, 263 p.

Kelley, V.C., 1977, Geology of Albuquerque Basin, New Mexico: Socorro, New Mexico Bureau of Mines and Mineral Resources Memoir 33, 60 p.

Kernodle, J.M., McAda, D.P., and Thom, C.R., 1995, Simulation of ground-water flow in the Albuquerque Basin, central New Mexico, 1901-1994, with projections to 2020: U.S. Geological Survey WaterResources Investigations Report 94-4251, 114 p.

Kernodle, J.M., Miller, R.S., and Scott, W.B., 1987, Threedimensional model simulation of steady-state groundwater flow in the Albuquerque-Belen Basin, New Mexico: U.S. Geological Survey Water-Resources Investigations Report 84-4353, 58 p.

Koterba, M.T., Wilde, F.D., and Lapham, W.W., 1995, Ground-water data-collection protocols and procedures for the National Water-Quality Assessment Program-Collection and documentation of water-quality samples and related data: U.S. Geological Survey Open-File Report 95-399, 113 p.

Lambert, P.W., 1968, Quatemary stratigraphy of the Albuquerque area, New Mexico: Albuquerque, University of New Mexico, Ph.D. dissertation, 329 p.

Lapham, W.W., Wilde, F.D., and Koterba, M.T., 1995, Ground-water data-collection protocols and procedures for the National Water-Quality Assessment Program-Selection, installation, and documentation of wells, and collection of related data: U.S. Geological Survey Open-File Report 95-398, 69 p.

Logan, L.M., 1990, Geochemistry of the Albuquerque municipal area, Albuquerque, New Mexico: Socorro, New Mexico Institute of Mining and Technology, Independent Study, 234 p.

Lozinsky, R.P., 1988, Stratigraphy, sedimentology, and sand petrology of the Santa Fe Group and pre-Santa Fe Tertiary deposits in the Albuquerque Basin, Valencia County, New Mexico: Socorro, New Mexico Institute of Mining and Technology, Ph.D. dissertation, $298 \mathrm{p}$.

Meister, R.T., ed., 1994, Farm chemicals handbook '94: Willoughby, Ohio, Meister Publishing Co., variously paged. 
Peter, K.D., 1987, Ground-water flow and shallow-aquifer properties in the Rio Grande inner valley south of Albuquerque, Bernalillo County, New Mexico: U.S. Geological Survey Water-Resources Investigations Report 87-4015, 29 p.

Popp, C.J., Ohline, R.W., Brandvold, D.K., and Brandvold, L.A., 1984, Nature of precipitation and atmospheric particulates in central and northern New Mexico, in Hicks, B.B., ed., Deposition both wet and dry: Boston, Butterworth Publishers, Acid Precipitation Series, v. 4, p. 79-95.

Pritt, J.W., and Raese, J.W., 1992, Quality assurance/quality control manual, National Water Quality Laboratory:

U.S. Geological Survey Open-File Report 92-495, 33 p.

Rose, D.L., and Schroeder, M.P., 1995, Methods of analysis by the U.S. Geological Survey National Water Quality Laboratory--Determination of volatile organic compounds in water by purge and trap capillary gas chromatography/mass spectrometry: U.S. Geological Survey Open-File Report 94-708, p. 26.

Sax, N.I., and Lewis, R.J., Sr., eds., 1987, Hawley's condensed chemical dictionary: 11th ed., New York, Van Nostrand Reinhold, 1288 p.

Scott, J.C., 1990, Computerized stratified random siteselection approaches for design of ground-waterquality sampling network: U.S. Geological Survey Water-Resources Investigations Report 90-4101, 109 p. Thatcher, L.L., Janzer, V.L., and Edwards, K.W., 1977, Methods for determination of radioactive substances in water and fluvial sediments: U.S. Geological Survey Techniques of Water-Resources Investigations, book 5 , chap. A5, 95 p.

Theis, C.V., 1938, Ground water in the middle Rio Grande Valley, in (U.S.) National Resources Committee, Regional Planning part VI--The Rio Grande joint investigation in the upper Rio Grande Basin in Colorado, New Mexico, and Texas, 1936-37: U.S. Government Printing Office, v. 1, p. 268-291.

Thomas, J.M., Welch, A.H., Lico, M.S., Hughes, J.L., and Whitney, Rita, 1993, Radionuclides in ground water of the Carson River Basin, western Nevada and eastern California, U.S.A.: Applied Geochemistry, v. 8, p. 447 471.

Thorn, C.R., McAda, D.P., and Kernodle, J.M., 1993, Geohydrologic framework and hydrologic conditions in the Albuquerque Basin, central New Mexico: U.S. Geological Survey Water-Resources Investigations Report 93-4149, 106 p.

Timme, P.J., 1995, National Water Quality Laboratory 1995 services catalog: U.S. Geological Survey Open-File Report 95-352, 120 p.

Titus, F.B., Jr., 1961, Ground-water geology of the Rio Grande trough in north-central New Mexico, with sections on the Jemez Caldera and Lucero Uplift, in Northrop, S.A., ed., Guidebook of the Albuquerque country: New Mexico Geological Society, 12th Field Conference, p. 186-192.

1963, Geology and ground-water conditions in eastern Valencia County, New Mexico: Socorro, New Mexico Bureau of Mines and Mineral Resources Ground-Water Report 7, 113 p.

Tuan, Yi-Fu, Everard, C.E., and Widdison, J.G., 1969, The climate of New Mexico: New Mexico State Planning Office, $169 \mathrm{p}$.

Umari, A.M.J., Martin, Peter, Schroeder, R.A., Puell, L.F.W., Jr., and Fay, R.G., 1993, Potential for groundwater contamination from movement of wastewater through the unsaturated zone, upper Mojave River Basin, California: U.S. Geological Survey WaterResources Investigations Report 93-4137, 116 p.

U.S. Department of Commerce, 1990, Master reference file for 1990 census.

1991, 1990 census of population and housing; Summary population and housing characteristics, New Mexico: 1990 CPH-1-33, variously paged. 1993, Climatological data annual summary, New Mexico: v. 97 , no. 13,36 p.

U.S. Environmental Protection Agency, 1996, Drinking water regulations and health advisories: U.S. Environmental Protection Agency Office of Water, February 1996, 11 p.

U.S. Geological Survey, 1986, Land use and land cover digital data from 1:250,000- and 1:100,000-scale maps: National Mapping Program technical instructions, Data users guide $4,36 \mathrm{p}$.

Werner, S.L., Burkhardt, M.R., and DeRusseau, S.N., 1996, Methods of analysis by the U.S. Geological Survey National Water Quality Laboratory--Determination of pesticides in water by Carbopak-B solid-phase extraction and high performance liquid chromatography: U.S. Geological Survey Open-File Report 96-216, 42 p.

Zaugg, S.D., Sandstrom, M.W., Smith, S.G., and Fehlberg, K.M., 1995, Methods of analysis by the U.S. Geological Survey National Water Quality Laboratory--Determination of pesticides in water by $C$ 118 solid-phase extraction and capillary-column gas chromatography/mass spectrometry with selected-ion monitoring: U.S. Geological Survey Open-File Report 95-181, 49 p. 
Appendix A.--Data for shallow ground water in the Albuquerque land-use study area

\section{EXPLANATION}

[Well numbers shown in figure 2. Station number: first six numbers, latitude; next seven numbers, longitude; last two numbers, sequence number of well at indicated latitude and longitude. --, no data; gal $/ \mathrm{min}$, gallons per minute; $\mu \mathrm{S} / \mathrm{cm}$, microsiemens per centimeter at 25 degrees Celsius ( $\operatorname{deg} \mathrm{C}$ ); $\mathrm{mm}$ of $\mathrm{Hg}$, millimeters of mercury; $\mathrm{mg} / \mathrm{L}$, milligrams per liter; bicarbonate water dis it, field, bicarbonate in unfiltered sample as determined in the field by incremental titration; alkalinity wat dis tot it, field, alkalinity in unfiltered sample as determined in the field by incremental titration; alkalinity wat wh gran $\mathrm{t}$, field $\mathrm{CaCO}_{3}$, alkalinity in unfiltered sample as determined in the field by gran titration; ammonia + organic dis., dissolved ammonia plus organic nitrogen; $\mu \mathrm{g} / \mathrm{L}$, micrograms per liter; alpha count, 2 sigma dissolved, 2-sigma precision estimate of indicated analysis; $\mathrm{pCi} / \mathrm{L}$, picocuries per liter; susp, suspended; Rn-222 2 sigma water, whole, 2-sigma precision estimate of indicated analysis; total, whole or unfiltered sample; diss, sample filtered through 0.7-micron-pore-size filter; rec, recovery; E, pesticide identified in a sample at a concentration less than method detection limit, concentration estimated] 


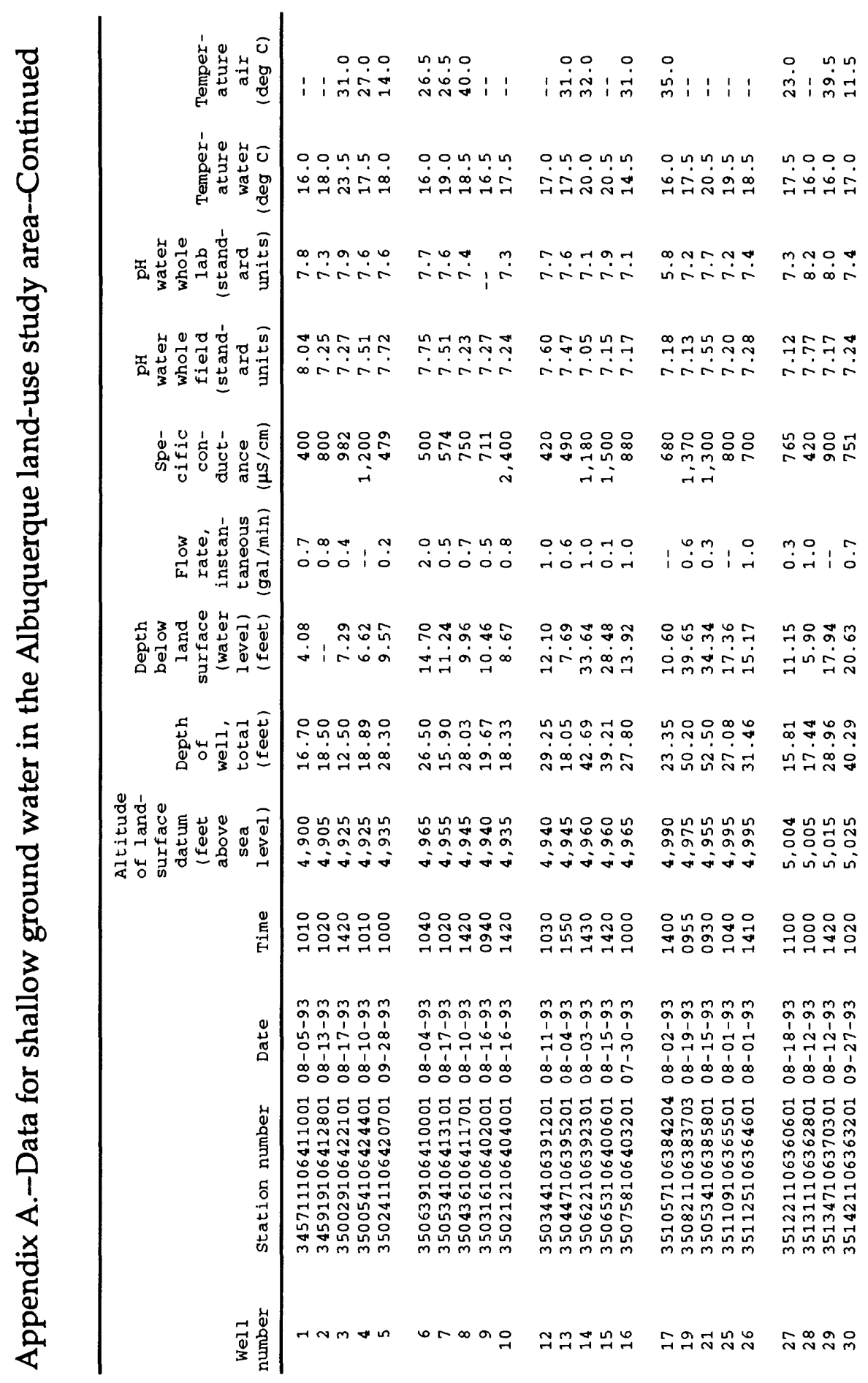




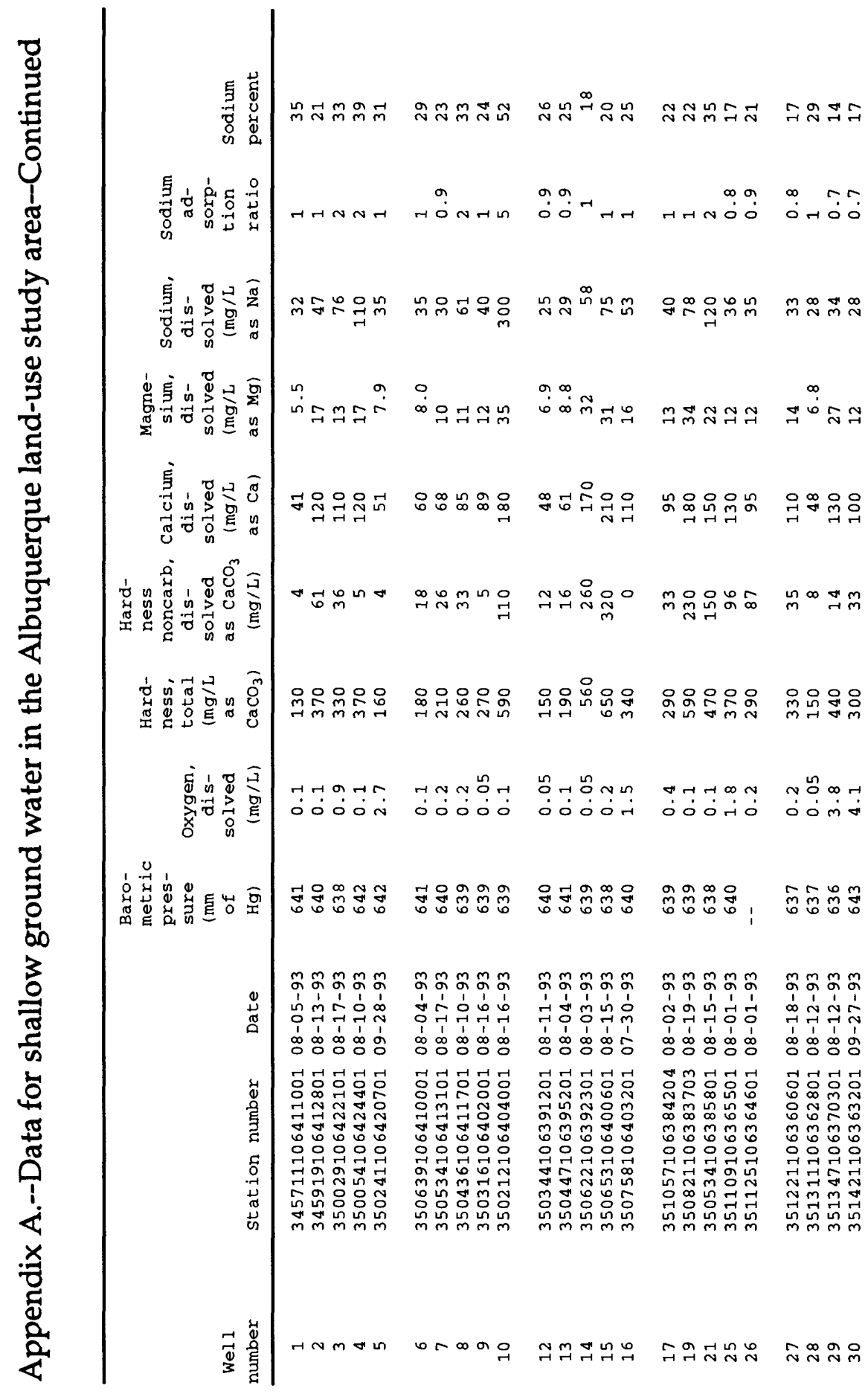




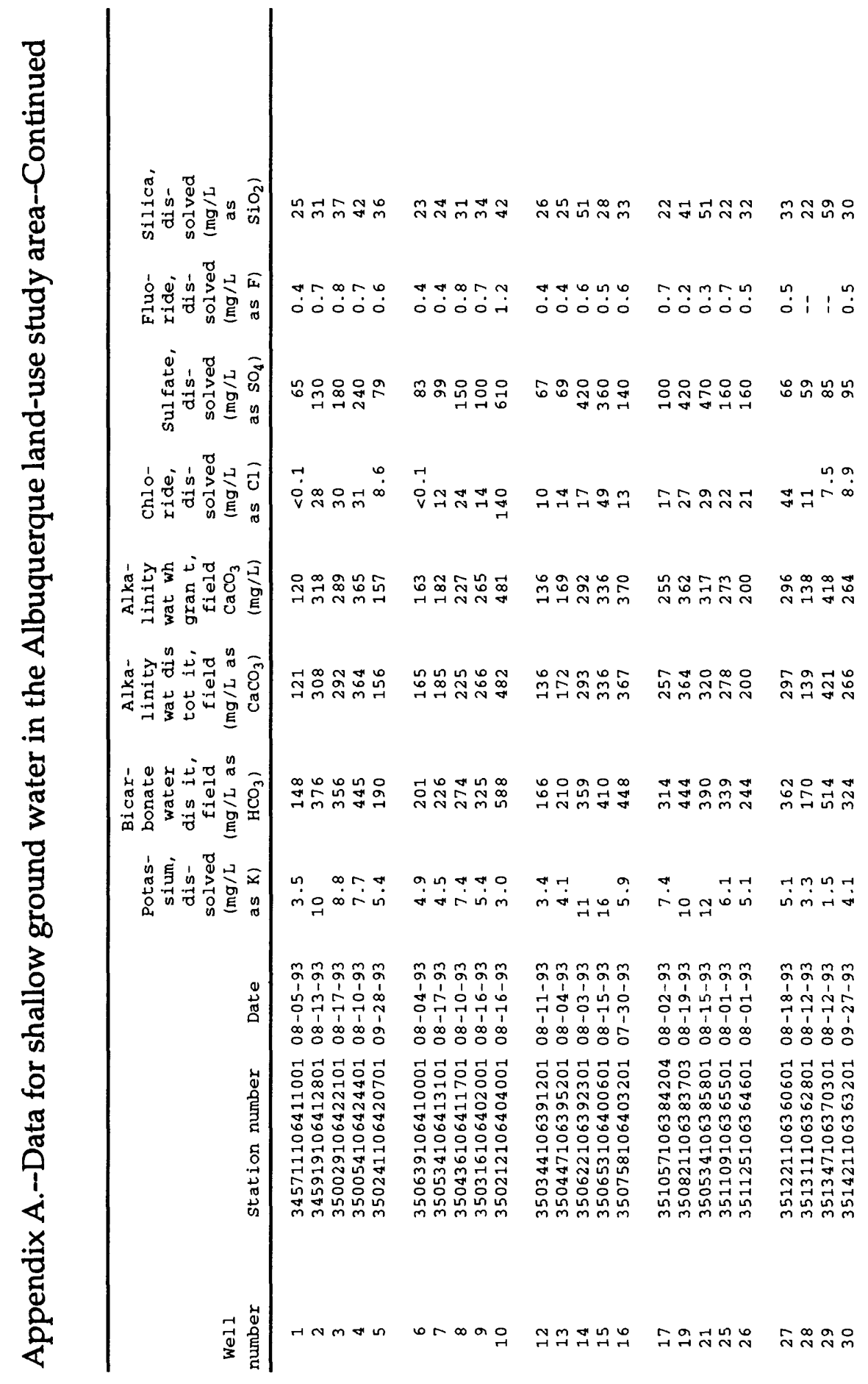




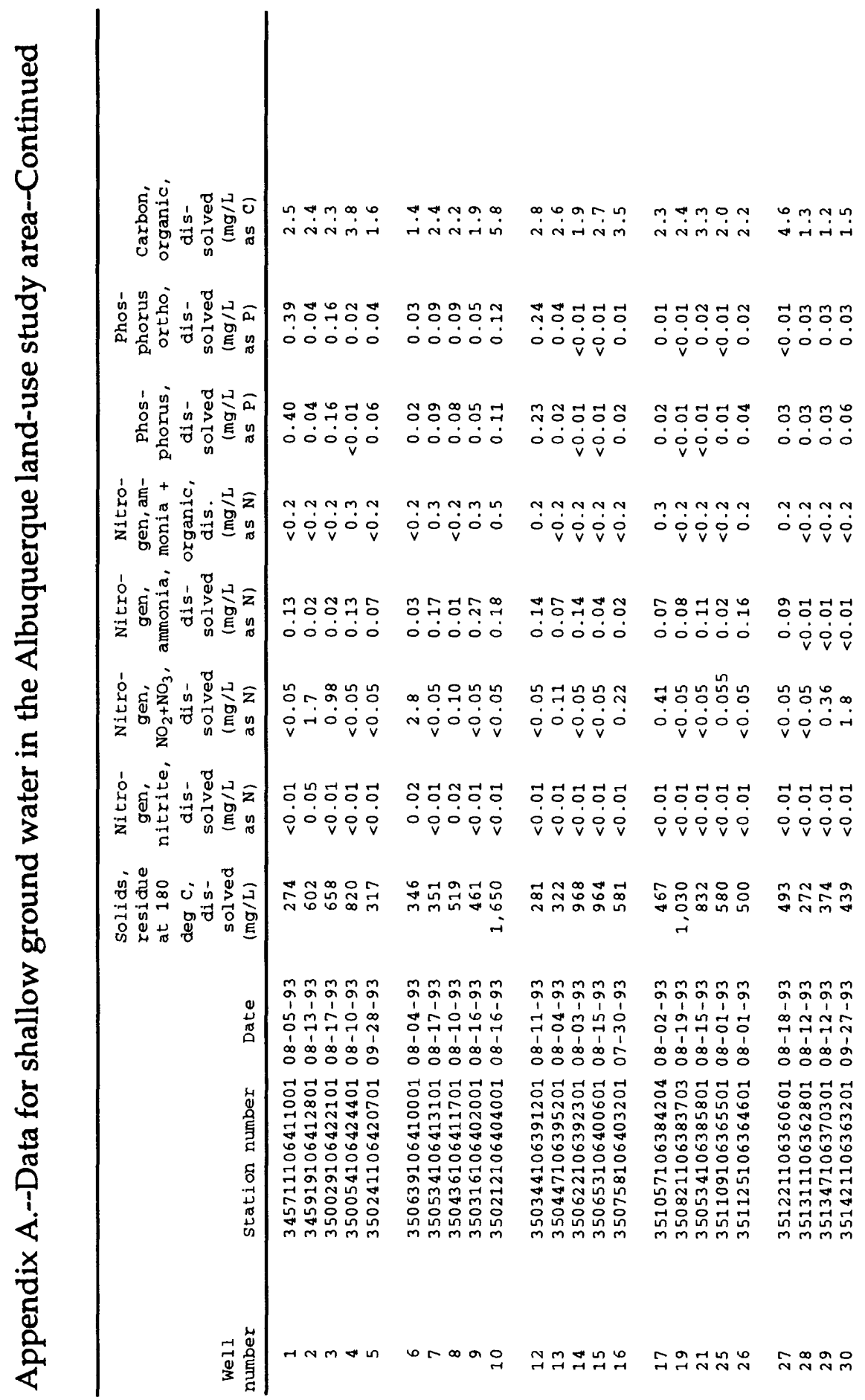




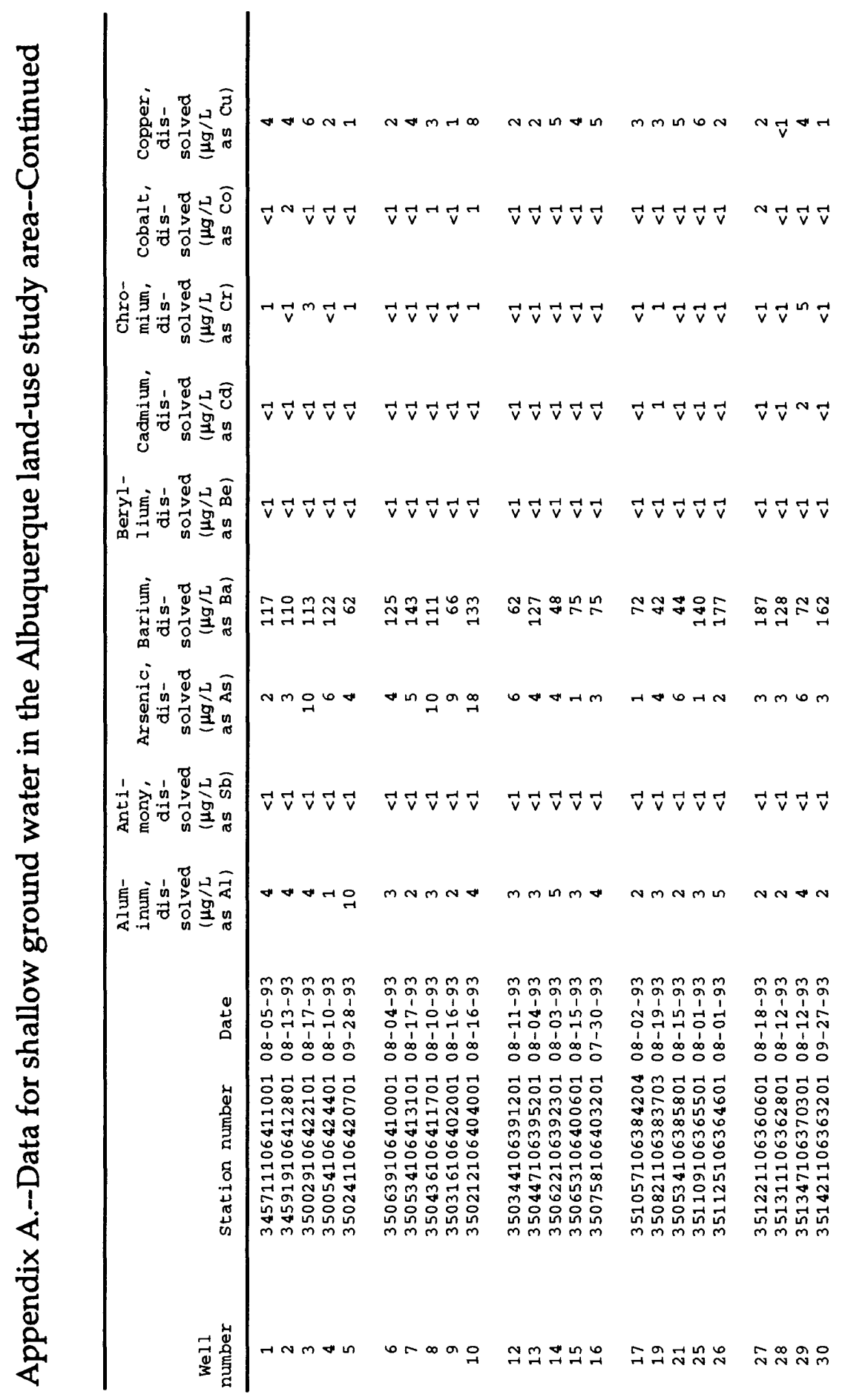




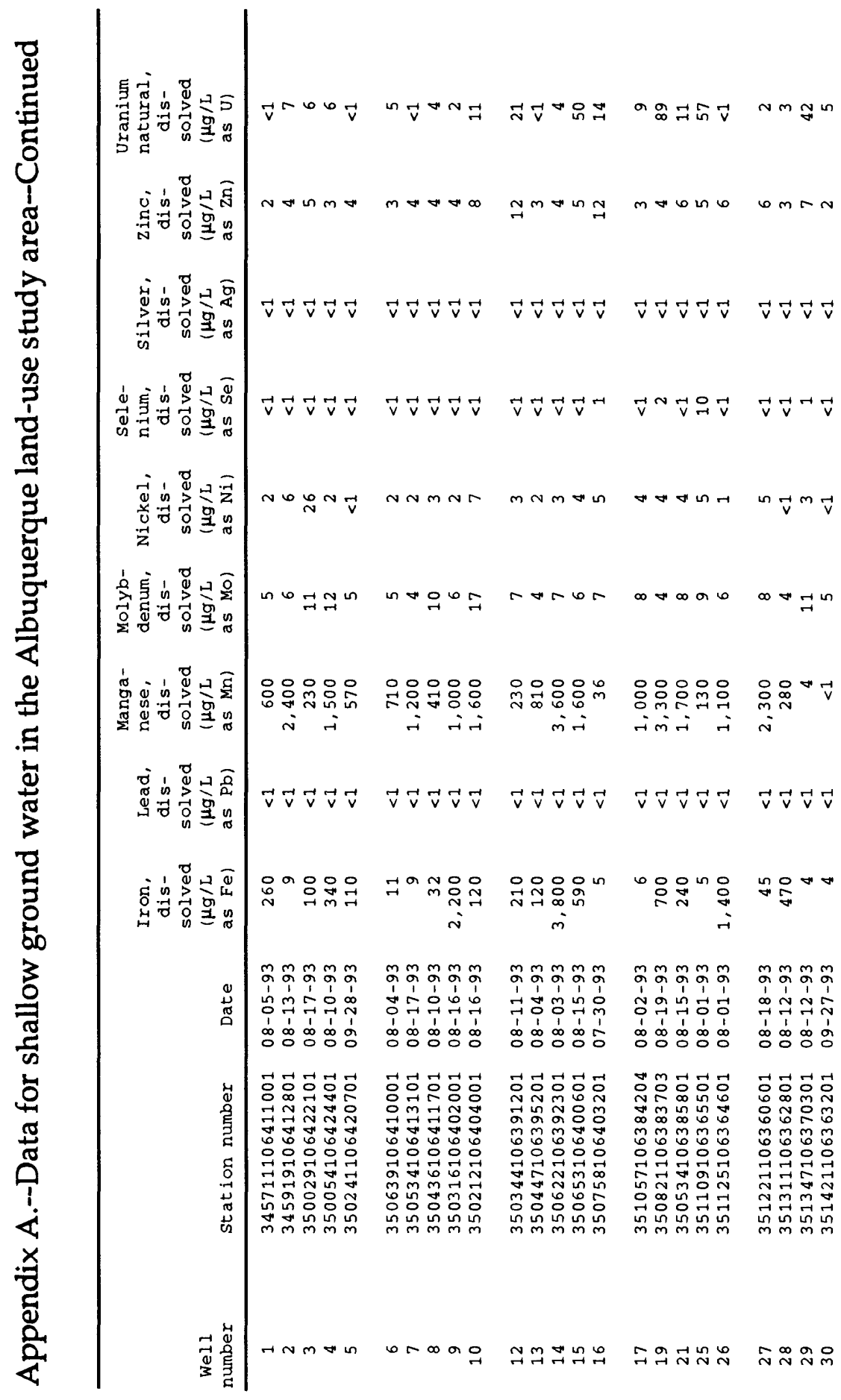




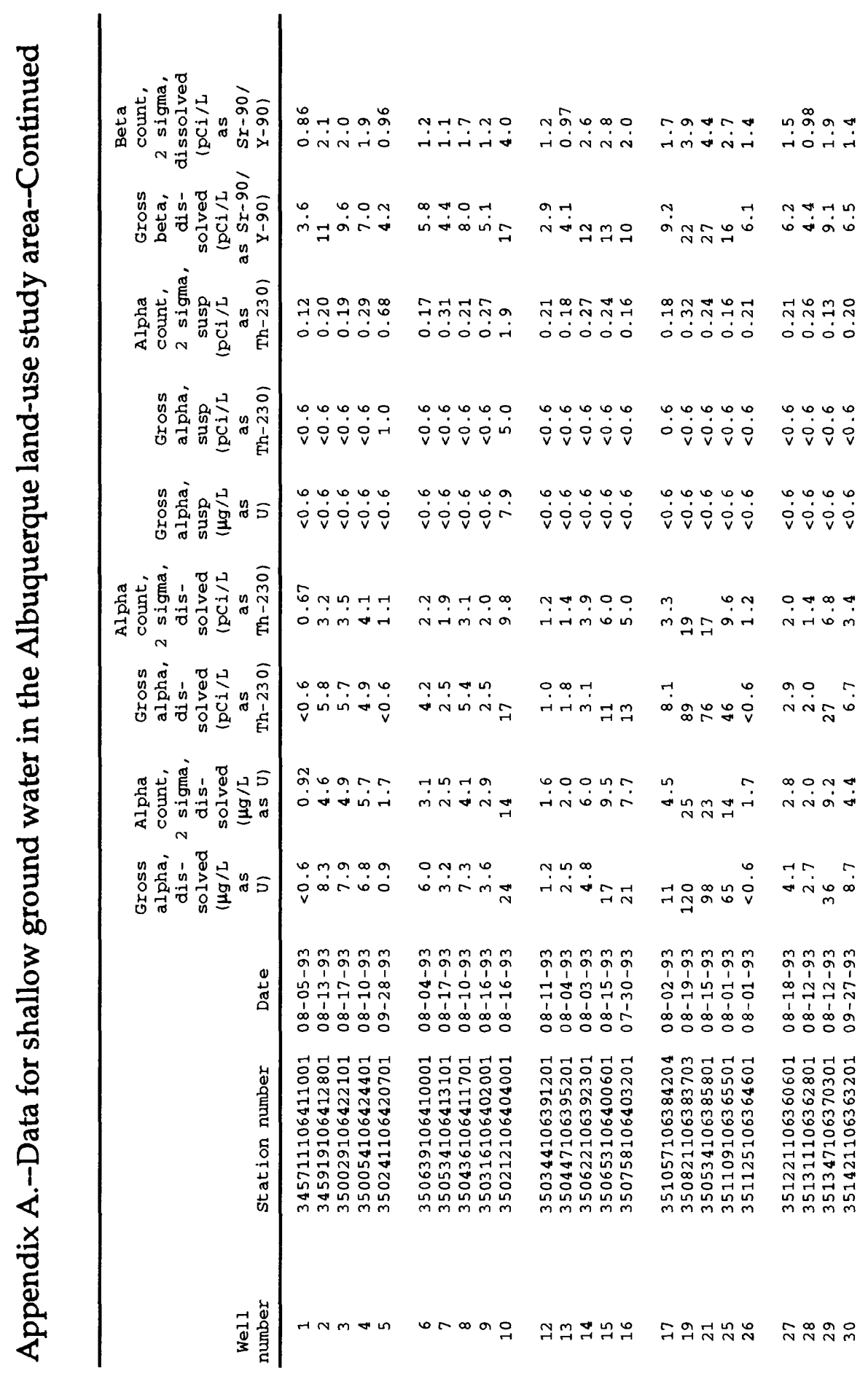




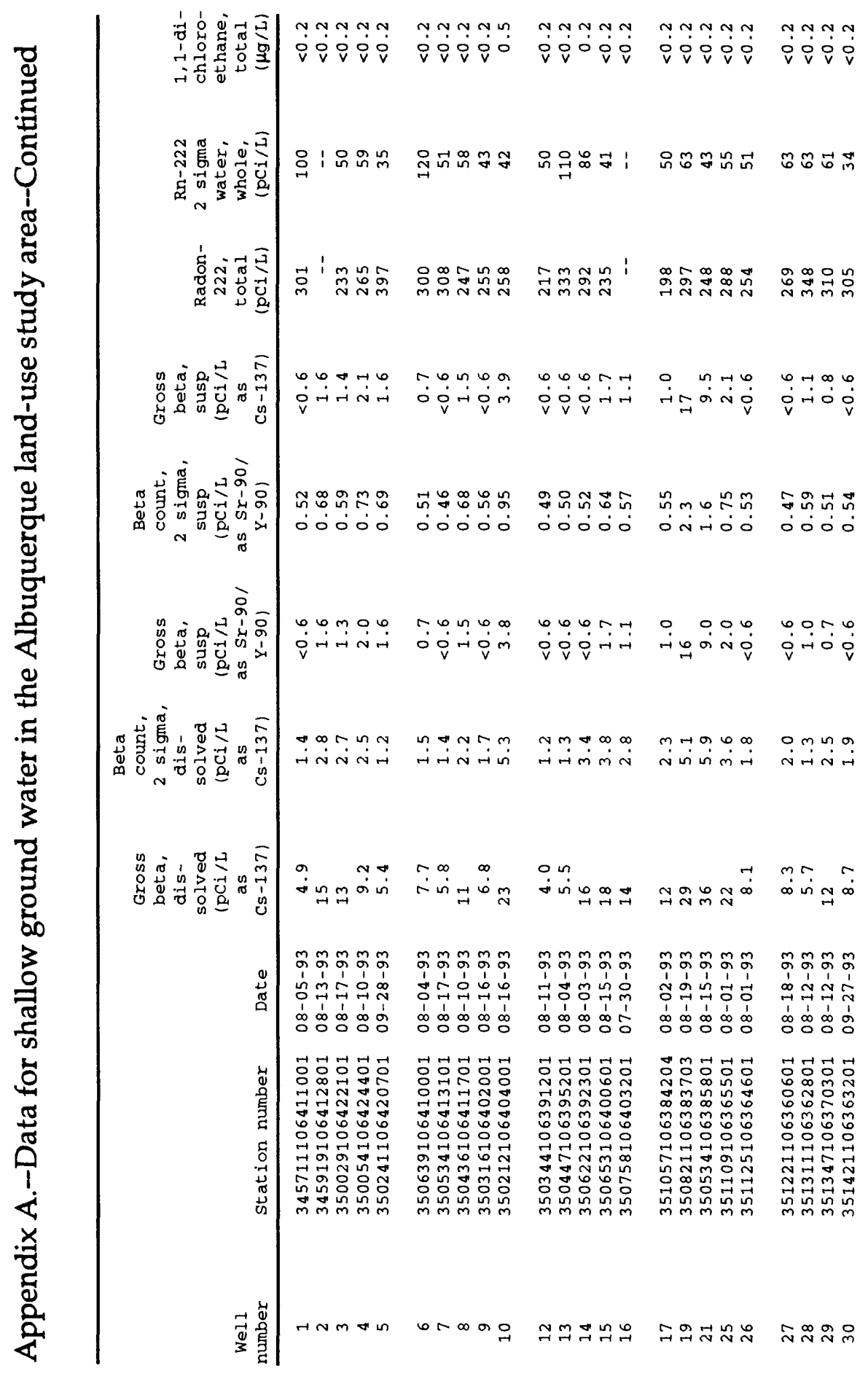




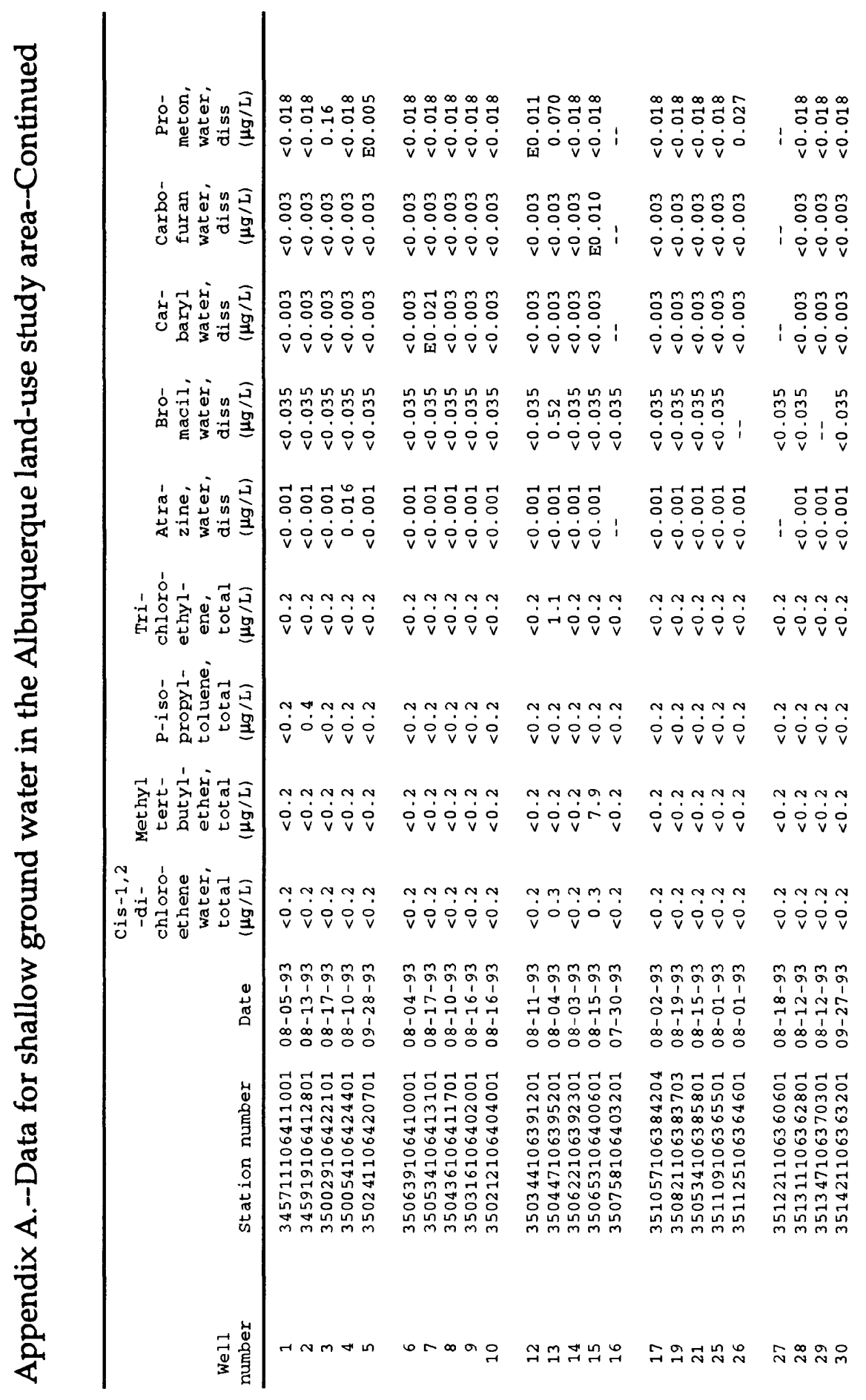




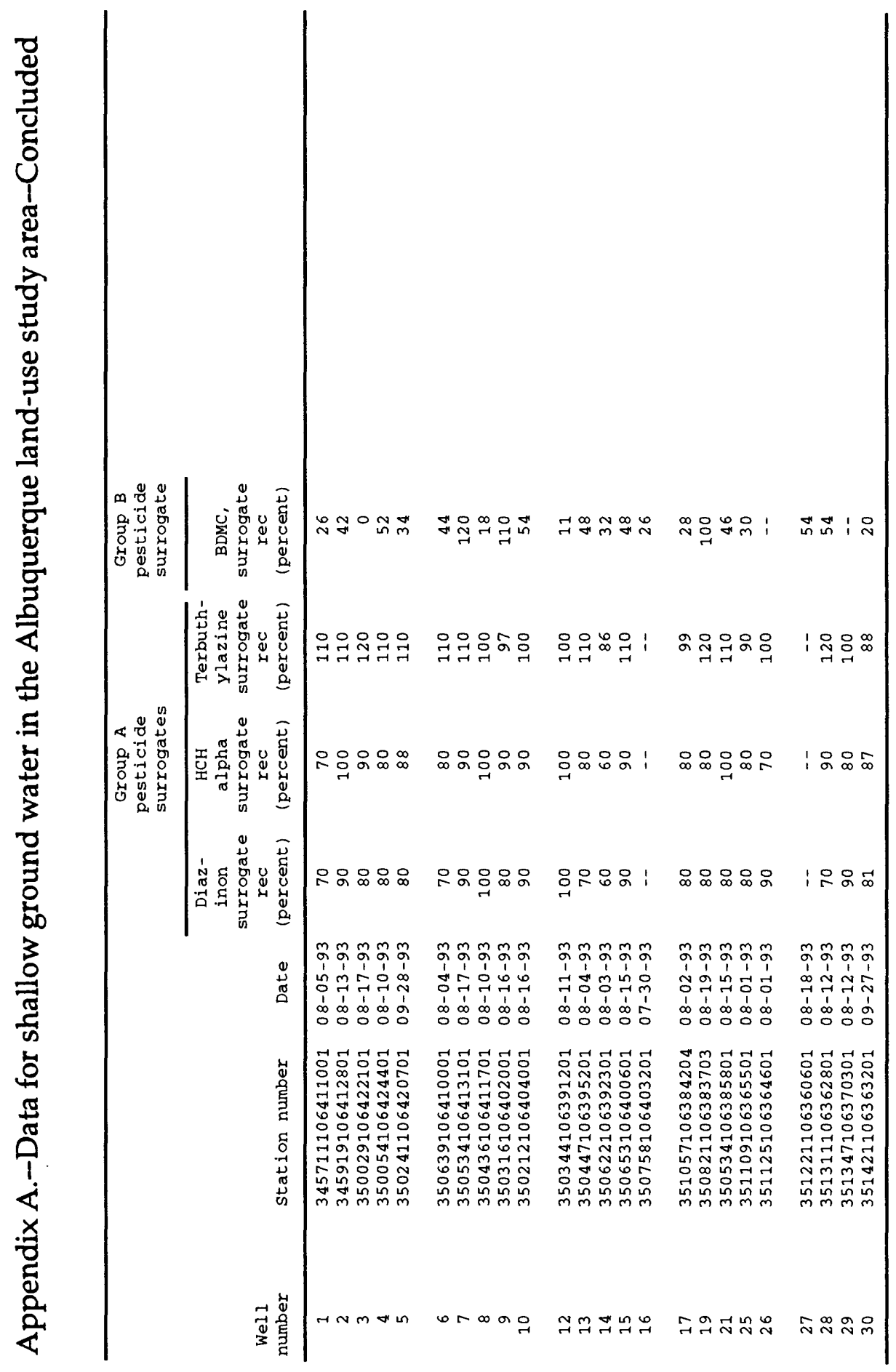


Appendix B.--Results of quality control/quality assurance samples

1. Results of replicate sampling

2. Percent recovery of volatile organic compound spikes

3. Percent recovery of Group A pesticide spikes

\section{EXPLANATION}

$\left[\mu \mathrm{S} / \mathrm{cm}\right.$, microsiemens per centimeter at 25 degrees Celsius $\left({ }^{\circ} \mathrm{C}\right)$; solids, residue at $180^{\circ} \mathrm{C}$; dissolved, dissolved solids determined by evaporating sample at $180^{\circ} \mathrm{C} ; \mathrm{mg} / \mathrm{L}$, milligrams per liter; <, less than; $\mathrm{NO}_{2}+\mathrm{NO}_{3}$, nitrite plus nitrate; $\mu \mathrm{g} / \mathrm{L}$, micrograms per liter; susp, suspended; --, no data; E, estimated] 


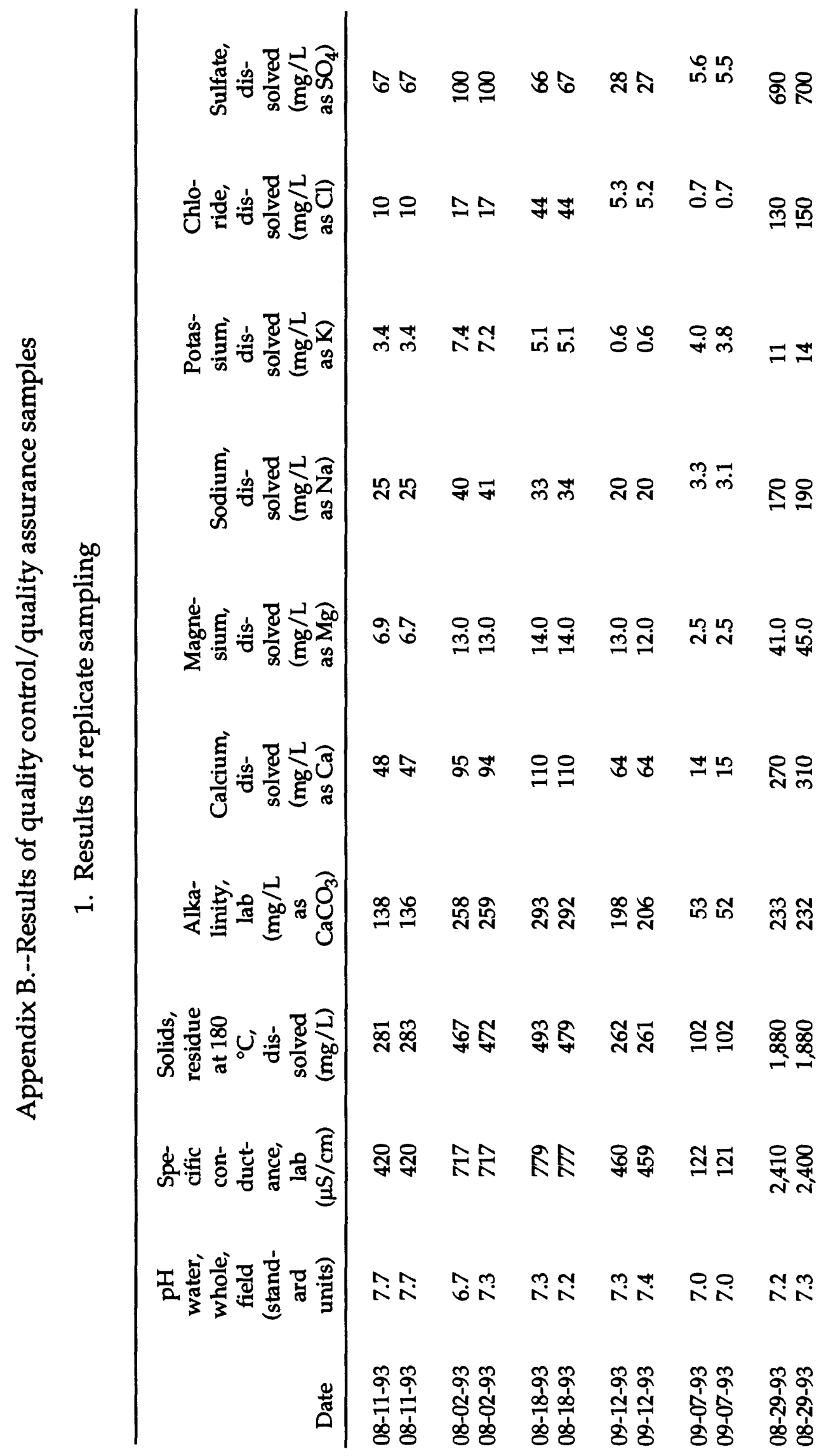




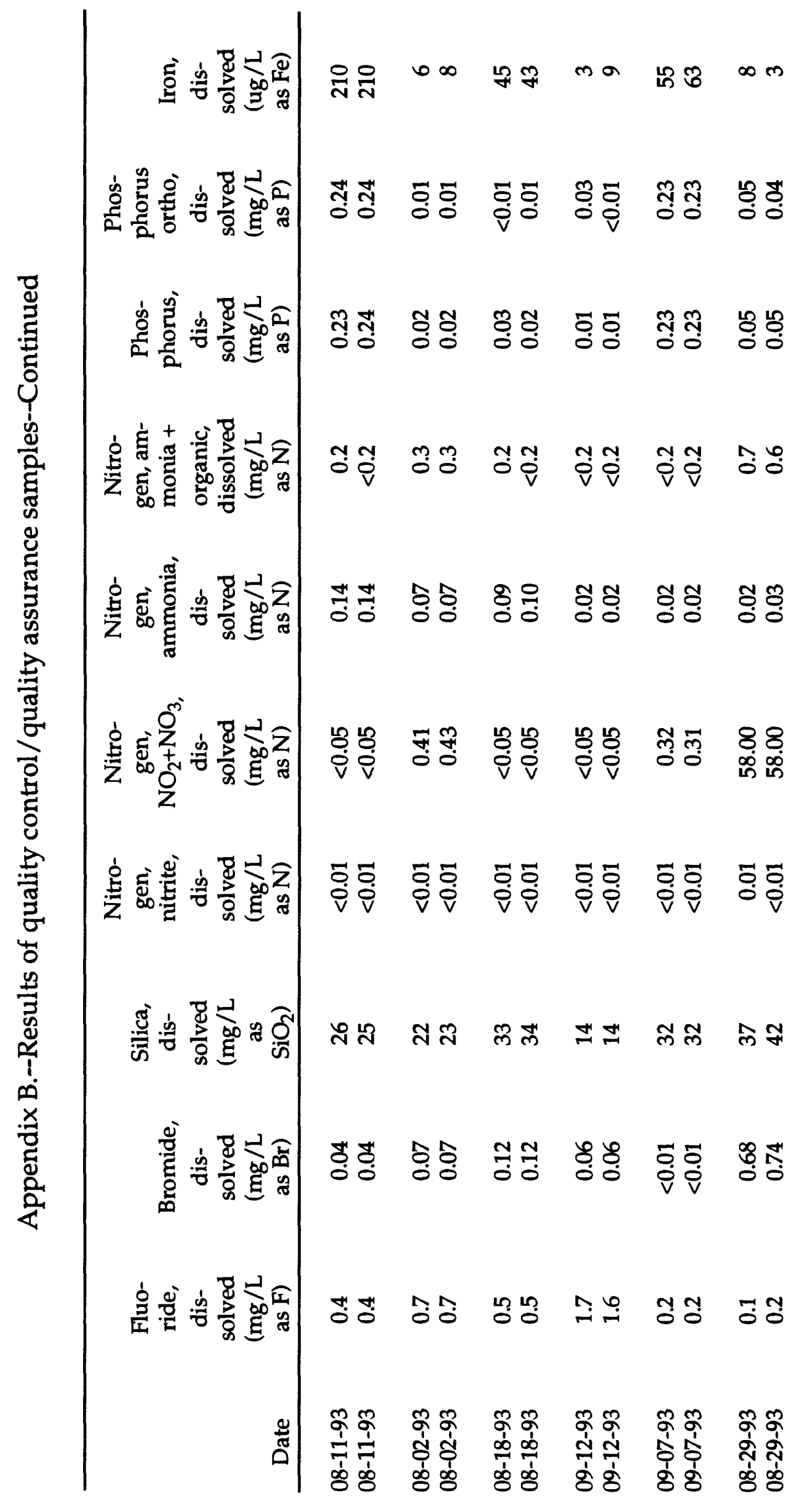




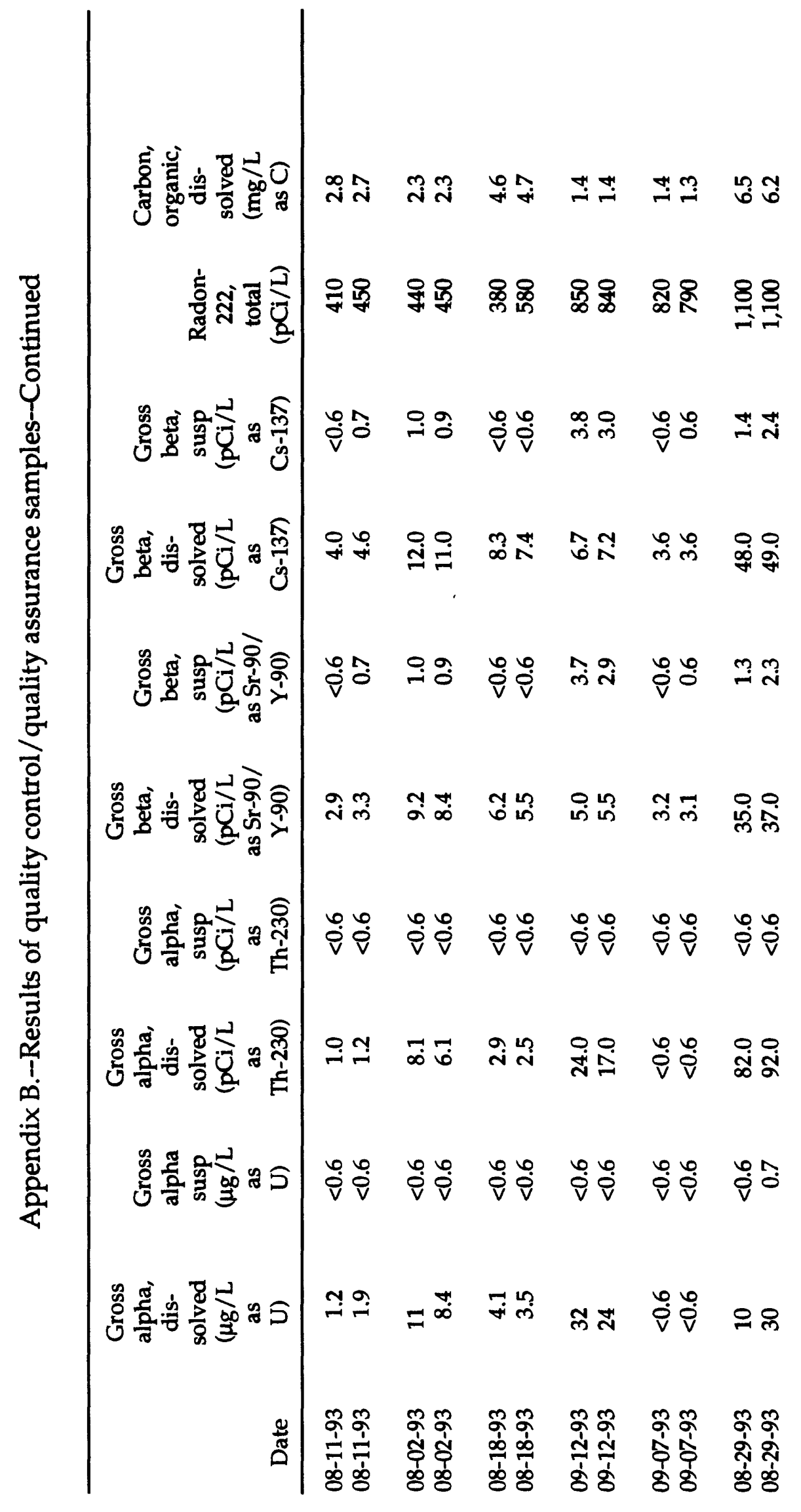




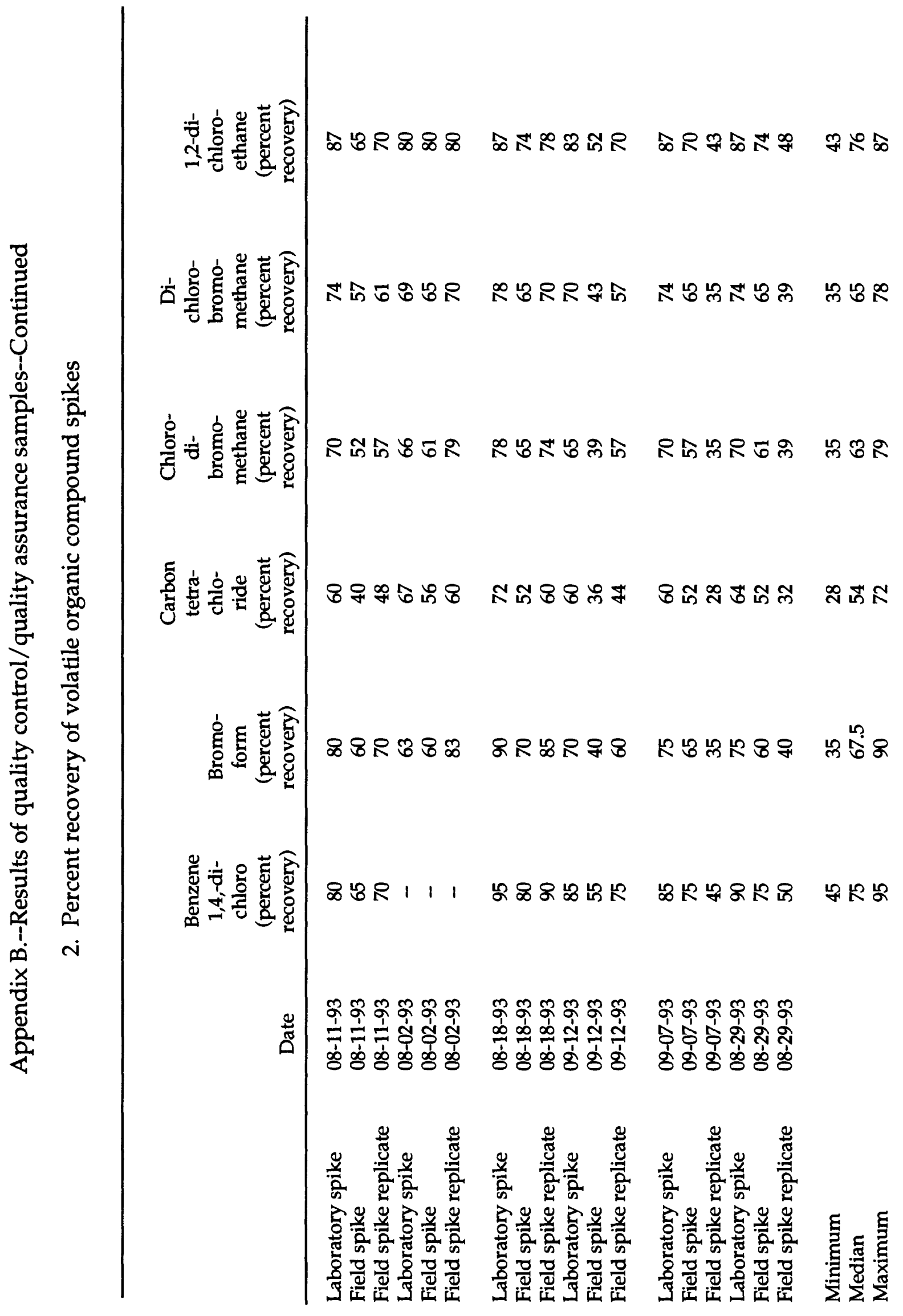




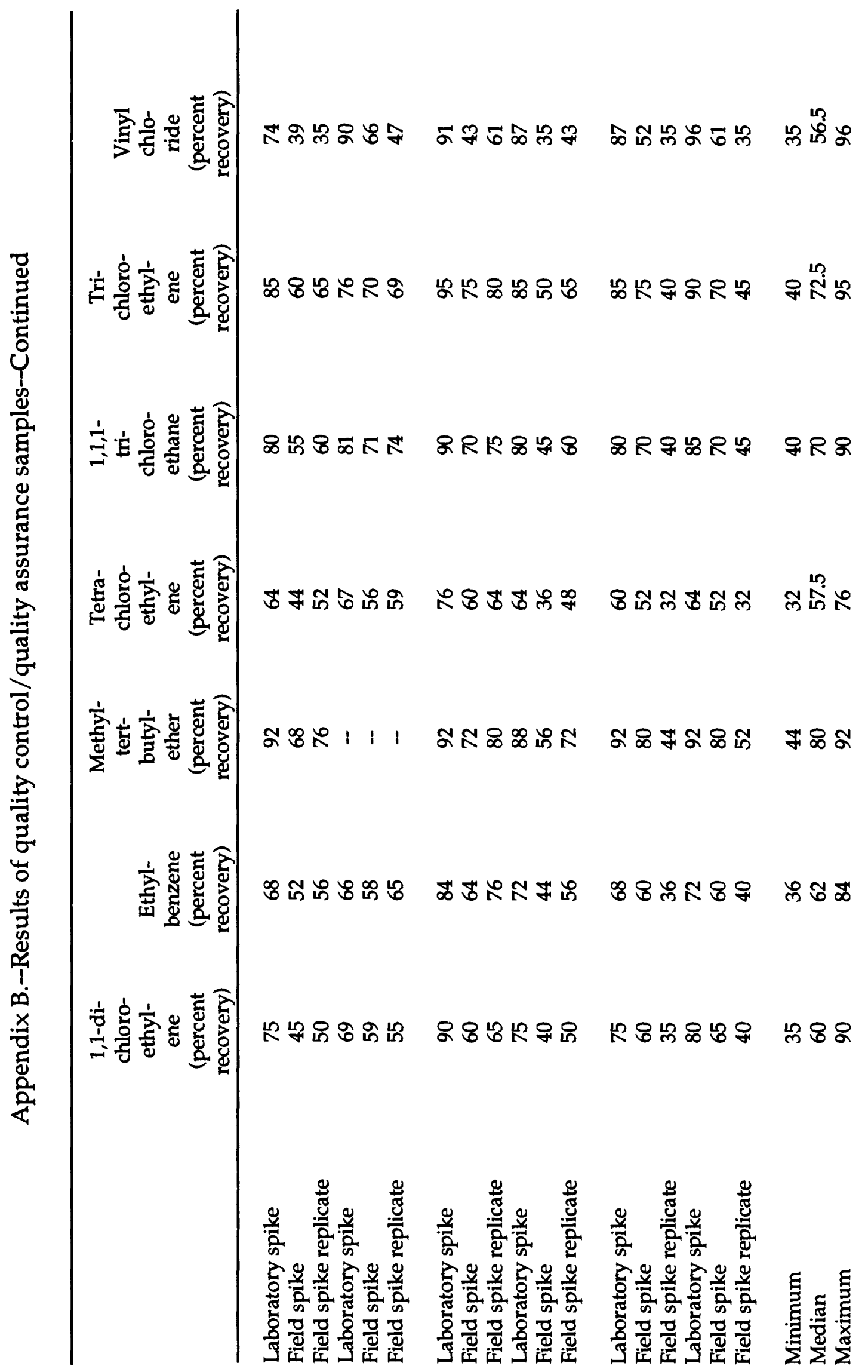




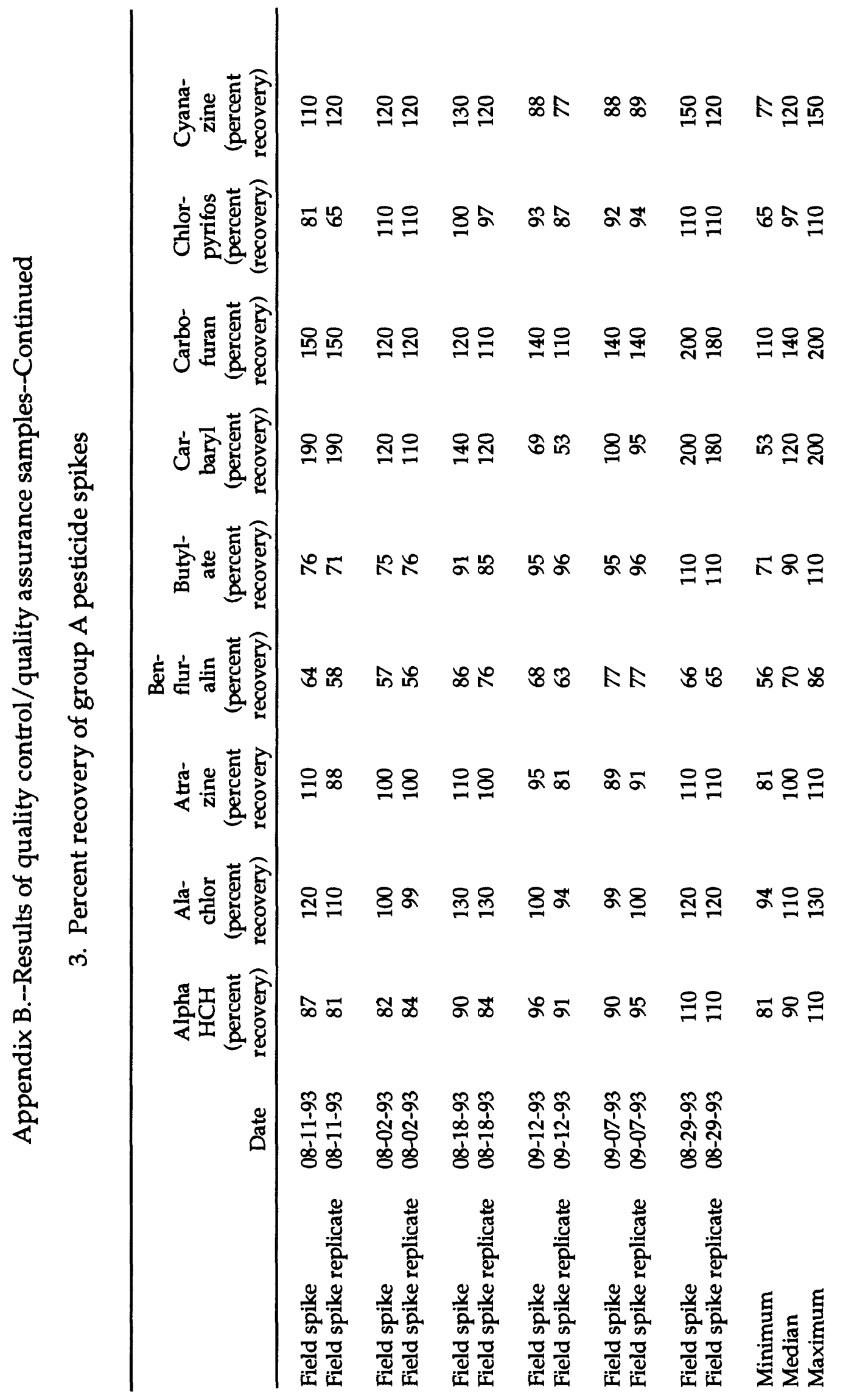




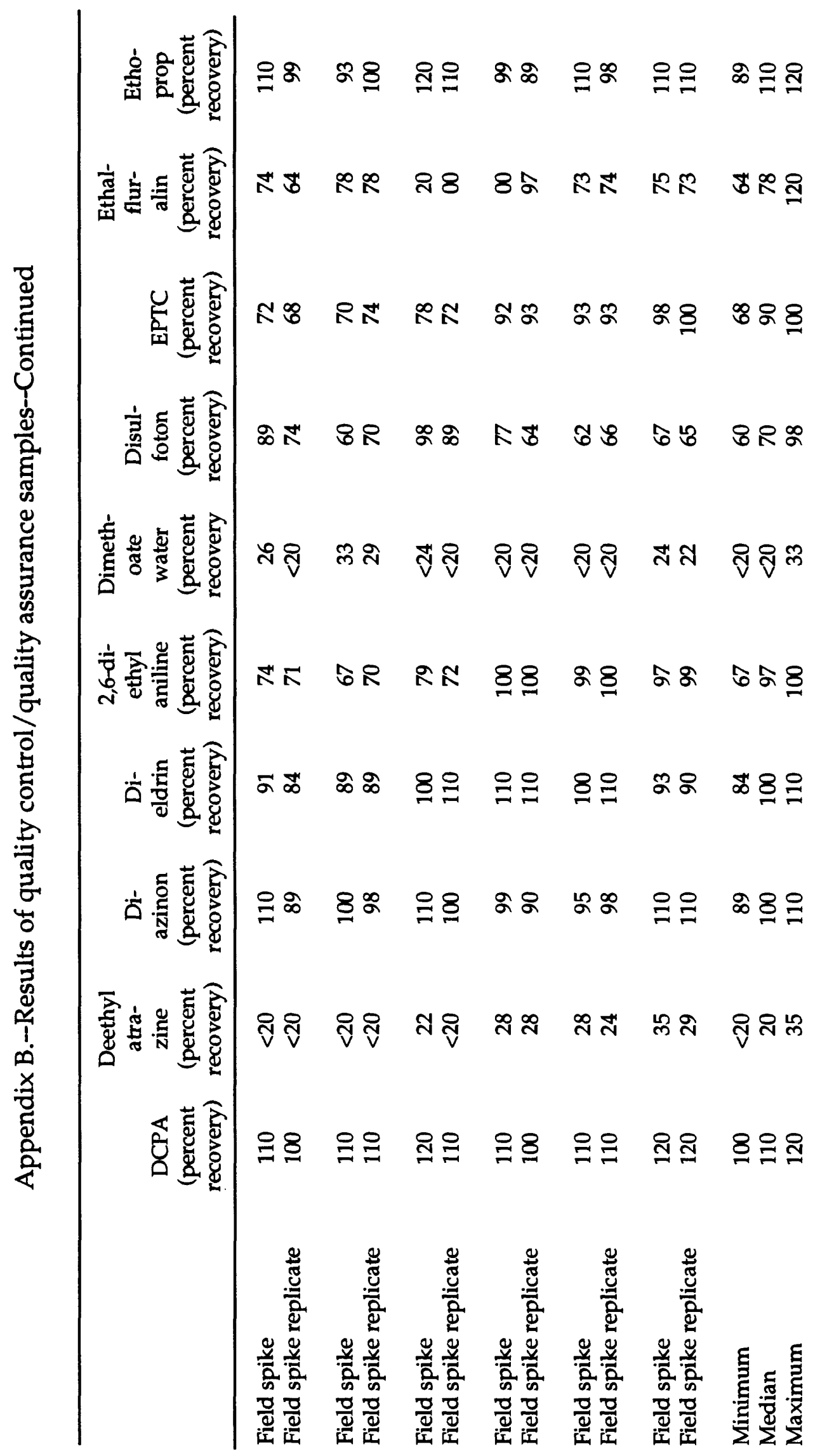




\begin{tabular}{|c|c|c|c|c|c|c|c|}
\hline 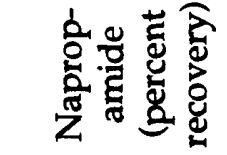 & సి 8 & సิฏ & 商 & \&్తి & そみ & 용 & ం 8 8 \\
\hline 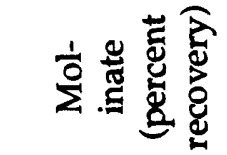 & $\infty \mathbb{E}$ & ER & 200 & ハ2 & 58 & 89 & A \\
\hline 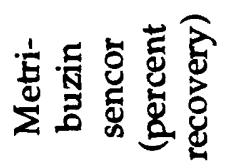 & F & 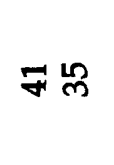 & К & ㄴoㅇㅇㅇ & הס & $\therefore 8$ & 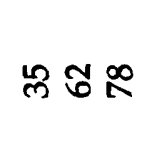 \\
\hline 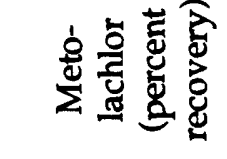 & ణ్లి జ్ & జ్రి స్ & 果吕 & 욤 & $\stackrel{g}{g}$ & 영여 & 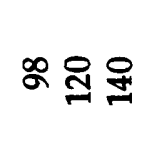 \\
\hline 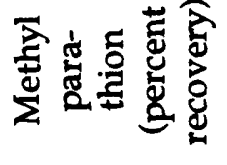 & $\infty 8$ & 80 & శ్రి ్లి & 요 & $\infty \bar{a}$ & $ळ \varpi$ & $8 \overline{00}$ \\
\hline 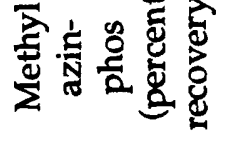 & ర్లై & ำ ำ & 원워 & $\infty$ & హ゙ & 82 & న 8.8 \\
\hline 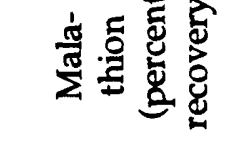 & సิฏ & รู & ద్లి స్తి & 88 & సू. & 욬 & జ 8 \\
\hline 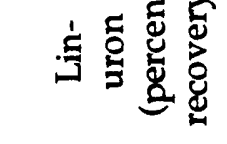 & 워 & 옥요 & F⿻ & 98 & త్స & ర్లిః & హి ఫ్రి \\
\hline 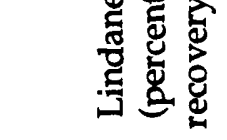 & 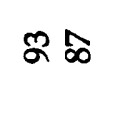 & ふぇ゙ & $8 \%$ & 요요 & 8 & 읔요 & $\infty 89$ \\
\hline 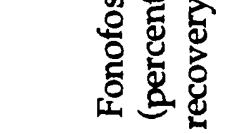 & 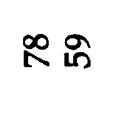 & & 주을 & $\infty$ & $\infty \infty$ & Һั2 & în \\
\hline & 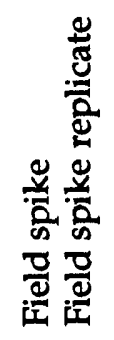 & 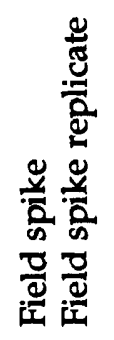 & 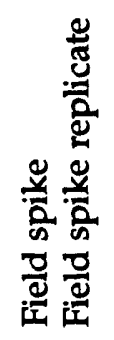 & 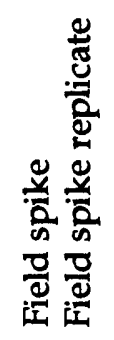 & 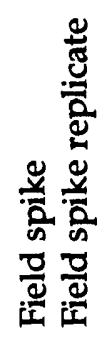 & 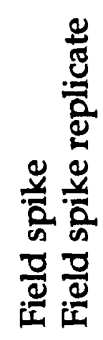 & 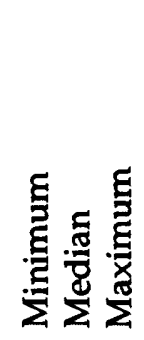 \\
\hline
\end{tabular}




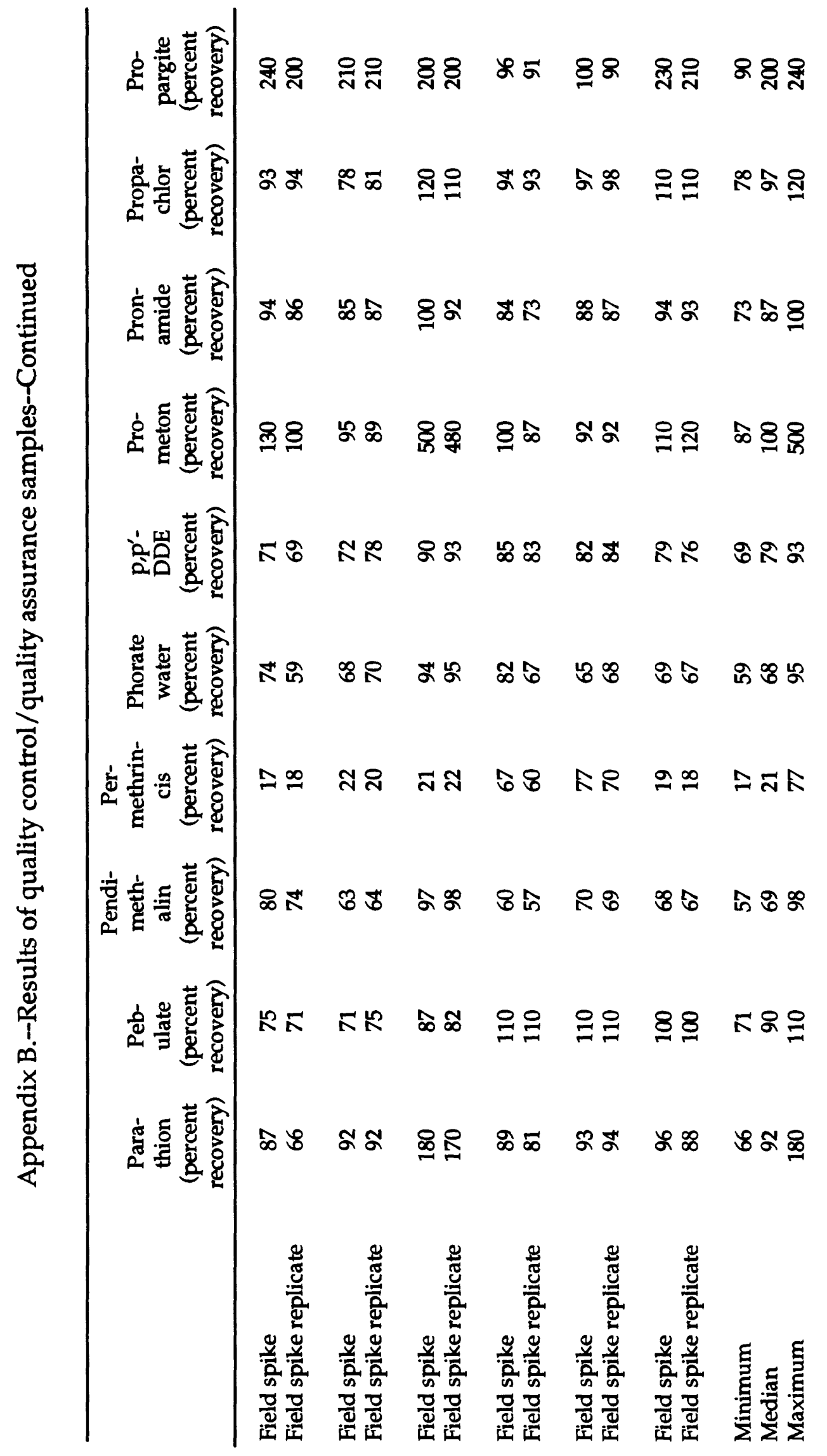




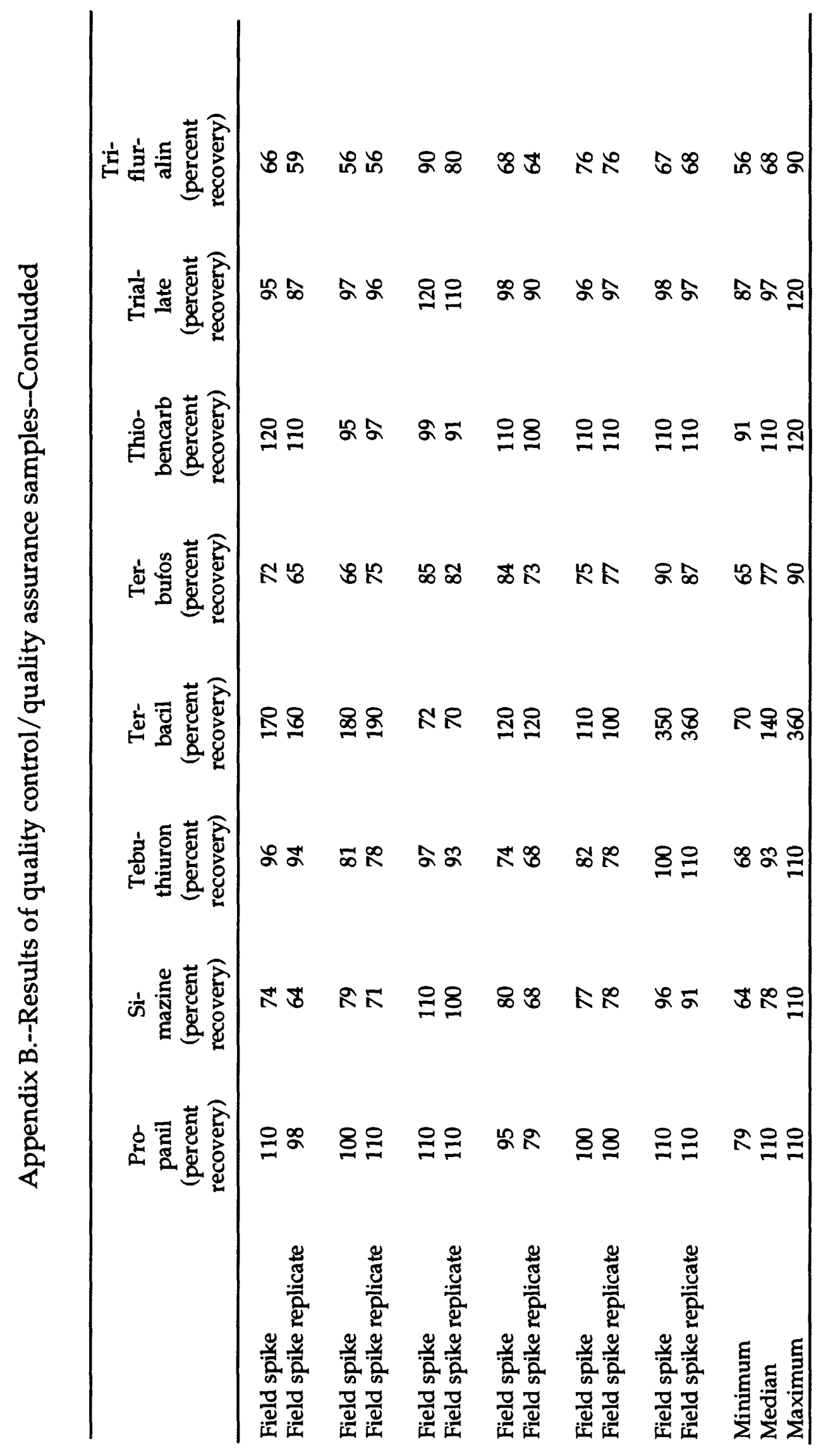

